\title{
EL PRINCIPIO DE COMPLEMENTARIEDAD Y LA LEY 975 DE 2005, A LA LUZ DE LA ACTIVACIÓN DE LA COMPETENCIA EVENTUAL DE LA CORTE PENAL INTERNACIONAL EN COLOMBIA
}

\author{
Maestría en Derecho Público \\ Universidad Santo Tomás \\ VIII COHORTE
}

Bogotá D.C.

Beatriz Helena Trujillo Betancourt 
Agradecimiento

A Dios, a mis padres, a mi familia, a María Constanza, mi querida tutora, a mis compañeras de batallas, de la vida, de especialización y maestría, especialmente Karen y Ximena; sin ellos no hubiera sido posible la redacción de este capítulo de mi historia... en momentos de penumbra iluminaron mi inspiración. 
EL PRINCIPIO DE COMPLEMENTARIEDAD Y LA LEY 975 DE 2005 A LA LUZ DE LA ACTIVACIÓN DE LA COMPETENCIA EVENTUAL DE LA CORTE PENAL INTERNACIONAL EN COLOMBIA 


\section{CONTENIDO}

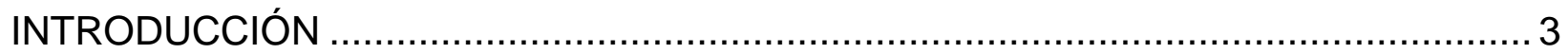

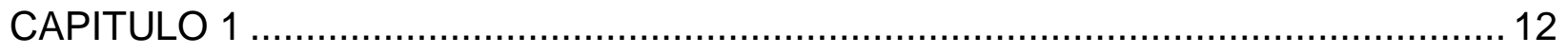

JUSTICIA TRANSICIONAL, LEY DE JUSTICIA Y PAZ, Y OBLIGACIONES INTERNACIONALES DEL ESTADO COLOMBIANO .............................................. 12

1.1. Justicia Transicional y límites a la capacidad punitiva del Estado .......................... 15

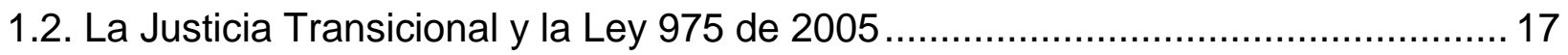

1.3. Problemas de aplicación de las normas de Justicia Transicional en Colombia...... 21

1.4. Elementos de contexto jurídico y de derechos de las víctimas ..............................23

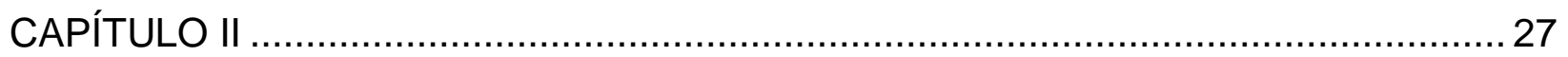

ELEMENTOS CONTEXTUALES DEL ESTANDAR INTERNACIONAL DE REPARACIÓN

2.1. Máximas internacionales sobre verdad y reparación ............................................ 28

2.2. Conflicto Armado no Internacional y Estándar Internacional de Justicia ................. 34

2.3. La Ley 975 a la luz de las diferencias entre el DIH y el DIDH ............................. 41

2.4. Elementos de Justicia Transicional para desarrollar un acuerdo de paz y

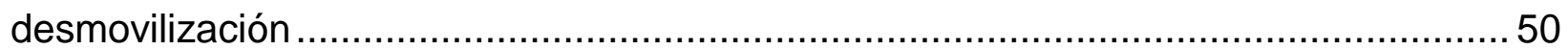

2.5. Sentencias que desarrollan el estándar de reparación .......................................53

2.6. El derecho a la Reparación a las víctimas de graves violaciones al DIH y al DIDH65 2.7. La jurisprudencia contencioso administrativa y la reparación a víctimas.............73

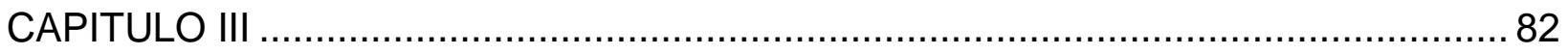

ELEMENTOS DE LA REPARACIÓN EN LA VIGENCIA DE LA LEY DE JUSTICIA Y PAZ

3.1. Resultados y costos de la ley de justicia y paz ................................................ 83

3.2 Dificultades y beneficios cualitativos del sistema de justicia y paz .......................... 86 Cuadro. 1. Cubrimiento de indemnizaciones en Justicia y Paz realizados por la Unidad

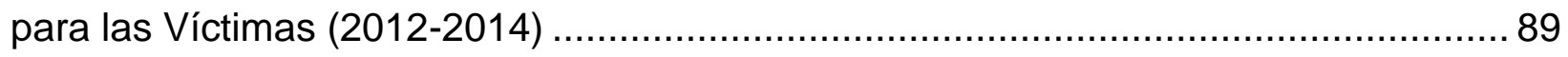

3.3 Análisis de las cuestionadas cifras del sistema de justicia y paz ...........................96

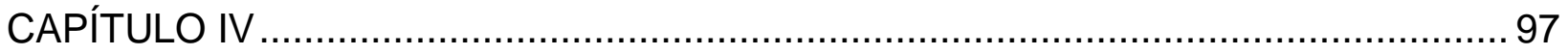


JUSTICIA TRANSICIONAL Y COMPETENCIA RESIDUAL DE LA CORTE PENAL

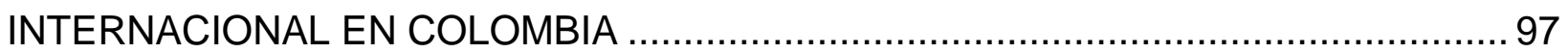

4.1. La Ley de Justicia y Paz y la violación del estándar de reparación.........................99

4.2. Relación entre la Ley de Justicia y Paz y la Jurisdicción Especial Para la Paz.... 102 4.2.1. Ruta de las víctimas en la JEP. 106

4.3. Elementos del estándar en el Sistema Interamericano de Derechos Humanos 107

4.4. Lecciones históricas para la discusión acerca del futuro de las víctimas del conflicto armado en Colombia en el escenario de pos acuerdo - una perspectiva antípoda acerca del perdón 113

4.5. Activación de la competencia de la Corte Penal Internacional en el caso Colombiano.

5. CAPÍTULO V 118 VERIFICACIÓN DEL ESTÁNDAR INTERNACIONAL DE JUSTICIA EN RELACIÓN CON LAS SENTENCIAS EMITIDAS POR LAS SALAS DE JUSTICIA Y PAZ EN VIRTUD DEL SISTEMA DE JUSTICIA TRANSICIONAL DE LEY 975 DE 2005. 120

5.1. Estándar de Justicia - no impunidad... 121

6. CONCLUSIÓN 120

Bibliografía 153 


\section{INTRODUCCIÓN}

No obstante, no existir una cifra que concite el consenso de la academia, historiadores tan reputados como el célebre profesor británico Antony Beevor estima, en su trabajo de investigación sobre la Segunda Guerra Mundial, que esta, produjo una cifra de más de cincuenta millones de víctimas humanas. También, fue la segunda conflagración orbital, el escenario en el que la conciencia de la humanidad se vería obligada a ser confrontada con los peores crímenes cometidos por quienes combatían, infortunadamente y en una parte muy significativa, realizados contra civiles y no combatientes. Como respuesta frente a esta terrible realidad, la comunidad internacional, aún conmocionada por la dantesca dimensión de la catástrofe que significó la guerra, se apresuró a desarrollar y emitir un sólido corpus jurídico internacional que tratara de subsanar y prevenir los excesos cometidos durante el transcurso de las conflagraciones bélicas. Surgieron entonces los convenios internacionales de Ginebra y posteriormente sus protocolos adicionales. Estos instrumentos internacionales nacidos como resultado de las deliberaciones acaecidas en el seno de la Organización de las Naciones Unidas, 
constituyen el cuerpo normativo internacional de Soft Law sobre el que descansa filosófica y doctrinalmente el Derecho Internacional Humanitario y el Derecho Penal Internacional.

En 1998 el mundo vería el surgimiento de la Corte Penal Internacional (CPI) un tribunal internacional de carácter permanente cuyo propósito general es el de ejercer en forma complementaria jurisdicción sobre personas nacionales de los estados parte, respecto de la comisión de los crímenes más graves de trascendencia internacional. La Corte fue concebida como un tribunal que contribuiría a subsanar las continuas críticas jurídicas e históricas que fueron formuladas en contra de los tribunales militares de Núremberg y Tokio tras la Segunda Guerra Mundial, así como en contra de los tribunales Ad Hoc implementados por el Consejo de Seguridad de la Organización de las Naciones Unidas para juzgar los graves crímenes cometidos en Ruanda y la Ex Yugoslavia. Tales críticas se centraban en esencia en que dichos tribunales eran abiertamente violatorios de los principios de tipicidad y legalidad, que son fundamento central del derecho penal en las sociedades democráticas, por cuanto estos fueron instaurados ex post facto, es decir, luego de la comisión de los hechos y las normas por las cuales se juzgaron a los responsables de la comisión de graves hechos en el marco de los conflictos, no estaban tipificados previamente. En virtud de ello, la comunidad internacional requería el establecimiento de un tribunal permanente que tuviera la capacidad de investigar, juzgar y sancionar los crímenes más graves cometidos en el desarrollo de confrontaciones armadas. 
Este tribunal vio la luz con el Estatuto de Roma, cuya negociación concluyó en la capital italiana en 1998, durante la "Conferencia Diplomática de plenipotenciarios de las Naciones Unidas sobre el establecimiento de una Corte Penal Internacional", y entró en vigor el 1ํ de julio de 2002. El Estado de Colombia es parte integrante del Estatuto de Roma, gracias a que fue uno de los 97 estados que participó en el proceso de negociación y firma del tratado internacional. En consecuencia, desde el año 2002 se activó la competencia sobre nuestro país y su jurisdicción interna para conocer en forma residual y complementaria las graves infracciones al Derecho Penal Internacional, específicamente los delitos de Lesa Humanidad, el Genocidio, Crímenes de Guerra y el Crimen de Agresión. La incorporación del Estatuto se dio a través de la Ley 742 de 2002 que modificaría lo dispuesto por el artículo 93 de la Carta Política. De la misma manera, el Estado de Colombia firmó una excepción por siete años contados a partir de la fecha de entrada en vigor del estatuto, para exceptuar la competencia del tribunal internacional respecto de los Crímenes de Guerra, razón por la que solo a partir del año 2009 la CPI es competente para conocer estas graves infracciones al DIH.

La entrada en vigor del Estatuto de Roma supuso la apertura de la posibilidad de conocimiento de situaciones de violación de derechos sujetas a la competencia material y temporal del alto tribunal internacional, en el escenario de agotamiento de las vías judiciales creadas por el Estado parte en el estatuto y solo en el supuesto eventual de que las mismas no cumplan con el propósito fundamental de garantizar justicia a las víctimas. El Estatuto de Roma contempla como parte nodal de su funcionamiento la materialización efectiva del principio de complementariedad en el supuesto descrito 
anteriormente, gracias a que su competencia residual se activaría en aquellas situaciones en las que en el marco de un conflicto armado interno o internacional, los máximos responsables de infracciones al $\mathrm{DIH}$, no sean hechos responsables individualmente en la respectiva jurisdicción penal nacional, ya sea como consecuencia de la incapacidad institucional del Estado parte o como producto de una decisión política de tal Estado de no proceder judicialmente en contra de ellos. Por tal consideración se tendrá que la competencia residual atribuida por el estatuto a la CPI se hará efectiva solo en el supuesto comprobado bajo el examen de la Fiscalía de la Corte que la jurisdicción penal de un Estado miembro no quiera o no pueda desarrollar una investigación, juzgamiento y sanción de los graves delitos cometidos en el marco de la confrontación bélica.

En los inicios del segundo milenio, el entonces presidente de la República de Colombia, Álvaro Uribe Vélez tomó la determinación política de desarrollar un proceso de negociación de paz con las organizaciones armadas al margen de la ley denominadas genéricamente: “Grupos Paramilitares" en virtud de ello surgió la Ley 975 de 2005 instrumento legal que sirvió de marco general para desarrollar el proceso de acuerdo y desmovilización de estos grupos ilegales y de otros actores armados que quisieran sumarse a la desmovilización y reintegración que ofrecía el gobierno en la ley. La condición que la Ley 975 impuso a los miembros de estas agrupaciones, como requisito para su desmovilización, fue la observancia estricta de las exigencias de: relatar en forma completa y taxativa toda la verdad, garantizar el acceso a la justicia de las víctimas y desarrollar un proceso de reparación efectiva de las mismas. Con lo anterior el 
instrumento legal pretendía observar los estándares internacionales de verdad, justicia y reparación que el Estado había incorporado en el escenario internacional, en el marco de los múltiples instrumentos de protección de Derechos Humanos, firmados por el Estado de Colombia, instrumentos tales como: Estatuto de Roma, La Convención Americana de Protección de los Derechos Humanos, el Pacto Internacional de Derechos Civiles y Políticos entre otros muchos de similar tenor. La naturaleza jurídica de este proceso se enmarca en el concepto de Justicia Transicional, que es una forma de excepción temporal de las normas derecho penal y de ponderación entre los principios jurídicos a la paz que reside en cabeza de todos los ciudadanos, y a la justicia y no repetición que está en cabeza de las víctimas de la confrontación armada.

Luego de más de una década de la aplicación de esta ley y sus decretos reglamentarios las cifras son, según los datos aportados en un reciente informe de la Contraloría General de la República hecho como parte de su propósito misional al proceso, aún muy precarias respecto del cumplimiento de los propósitos con que fue instaurada la Ley ${ }^{1}$. Puesto qué y de acuerdo con el informe, en la última auditoría hecha al proceso de implementación de la Ley por el órgano de control, publicada en su página en el año 2016, se sostiene que, de un total de 2.378 postulados activos en este sistema, solo se han impartido 47 sentencias condenatorias que cobijan 195 postulados, y han sido utilizados más de 11.1 billones de pesos en la ejecución de los distintos componentes que integran el proceso que diseñó la ley.

\footnotetext{
${ }^{1}$ El informe de la Contraloría General de la República se titula: Análisis sobe los resultados y costos de la Ley de Justicia y Paz. $Y$ puede consultarse en el siguiente enlace: https://www.contraloria.gov.co/documents/20181/466201/An\%C3\%A1lisis+sobre+los+resultados+y+cost $\underline{\text { os+de+la+Ley+de+Justicia+y+Paz/dcce2907-f669-42b8-8857-7e14750cc467?version=1.0 }}$
} 
Debido a lo anterior, surge el interrogante central de este trabajo de investigación, ¿Puede ser activada la competencia residual de la Corte Penal en Colombia en virtud de la aplicación del principio de complementariedad, como consecuencia de la deficiente implementación de la Ley 975 de 2005 en Colombia?

Como respuesta provisional al planteamiento central de este trabajo, se tiene que esta situación eventual se presentaría como resultado de que los propósitos con los que fue instituida la Ley de Justicia y Paz, en virtud de los cuales, los derechos de las víctimas a la verdad, la justicia y la reparación, no han sido cumplidos por el Estado Colombiano, como producto de la aplicación de este instrumento legal, y que en el caso de la satisfacción del estándar internacional de Justicia en relación con la comisión de graves delitos contra la humanidad, ni el proceso ni las condenas impuestas a los responsables de estas conductas satisfacen los derechos de las víctimas. Por lo cual, se daría el supuesto del artículo 17 de la CPI en el que el Estado tiene poca capacidad judicial o incluso falta de voluntad y se habilitaría la competencia residual de este tribunal.

En virtud de lo expuesto, tenemos que el objetivo central será: establecer si la Ley 975 de 2005 examinada a la luz del principio de complementariedad, cumple con la obligación del Estado Colombiano de adelantar investigaciones y procedimientos judiciales contra los responsables de los crímenes bajo competencia de la CPI. 
Para resolver el interrogante planteado se plantean como objetivos específicos, los siguientes:

a. Analizar conceptos como Justicia Transicional desde el punto de vista del derecho internacional público, estándares internacionales de reparación por la flagrante vulneración a Derechos Humanos y al Derecho Internacional Humanitario; así como la Ley 975 de 2005, su origen, propósitos y el estándar de reparación local en el marco del derecho internacional.

b. Realizar un balance de la aplicación de la ley 975 de 2005 luego de más de una década de su entrada en vigor para establecer si los presupuestos insertos en la misma de verdad, justicia y reparación han sido materializados.

c. Desarrollar un análisis conceptual y teórico del principio de complementariedad para determinar si el mismo se hace válido para subsanar los vacíos legales de acceso a la justicia por parte de las víctimas de los Grupos Armados Organizados al Margen de la Ley (GAOML), insertos en la Ley 975 de 2005.

d. Determinar el grado de cumplimiento de los supuestos de verdad, justicia y reparación desarrollados por la Ley 975 de 2005 para establecer el grado de propensión de la activación de la competencia residual de la CPI en el caso colombiano. 
La estrategia metodológica que empleará este trabajo, se dividirá en dos partes, de un lado se empleará un método de análisis de forma investigativa básica, descriptiva y analítica, es decir aquella investigación que se dedica al examen atinente a las normas jurídicas, su objeto de conocimiento es la norma jurídica, la doctrina y la jurisprudencia jurídicas, esta forma de investigación se dedica a examinar las problemáticas de la norma sustantiva y procesal y las distintas relaciones establecidas entre ellas. En segundo término, y referido al tipo de investigación es posible aseverar que esta investigación tomará como referente, el tipo denominado como investigación correlacional, es decir el tipo de investigación que integra la respuesta a una pregunta genérica que se ubica en contexto general de la investigación, tratando de relacionar y responder a dos tesis o premisas consideradas en su particularidad como variables.

En cuanto al método que empleará la investigación, esta optará por el empleo del denominado método teórico, de inducción y deducción, la inducción como método investigativo, es una vía de estudio, que parte de los hechos singulares y pasa a proposiciones generales para llegar al conocimiento en términos genéricos. La inducción y la deducción son herramientas metodológicas inseparables, entre sí, y ambas constituyen momentos diferenciados del conocimiento jurídico - científico. De conformidad con lo dicho anteriormente, y para tratar de corroborar las tesis metodológicas esbozadas antes, la metodología utilizada en la elaboración especifica de este proyecto, será esencialmente el análisis de caso, que se centrará en el análisis de los argumentos y justificaciones teóricas y jurídicas de la activación eventual de la 
competencia residual de la CPI en el caso colombiano en virtud de la aplicación material del principio de complementariedad.

Finalmente, la realización de esta investigación encuentra su justificación en el episodio histórico suscitado con la desmovilización de los Grupos Armados Organizados Al Margen de la Ley, en su mayoría paramilitares, en virtud de la Ley 975 de 2005, en curso del gobierno de Álvaro Uribe Vélez; los hechos escalofriantes de violencia ocurridos en curso del actuar de esos grupos, que se han develado con ocasión de las versiones de los perpetradores, de las víctimas, demandan investigar y analizar actualmente cómo el Estado Colombiano ha afrontado la situación humanitaria, si se han cumplido los objetivos de Justicia, Verdad, Reparación y No Repetición de dicha normatividad, si se cumplen los estándares internacionales de reparación y en caso contrario, si la comunidad internacional podría exigir eventualmente del Estado su cumplimiento y a través de que herramientas.

Resulta imprescindible efectuar este análisis en el momento histórico de implementación de los Acuerdos de paz con las FARC a través de la Justicia Especial para la Paz a partir de marzo de la corriente anualidad; es necesario observar el pasado críticamente, reconocer los aciertos, así como los errores cometidos en la aplicación del proceso de justicia transicional enmarcado en la Ley 975 de 2005, revisar el proceso de reivindicación que históricamente se debe a las víctimas del conflicto armado, para poder seguir adelante en la búsqueda de uno de los fines constitucionales esenciales del Estado Colombiano, la paz. 


\section{CAPITULO 1}

\section{JUSTICIA TRANSICIONAL, LEY DE JUSTICIA Y PAZ, Y OBLIGACIONES INTERNACIONALES DEL ESTADO COLOMBIANO}

La potestad sancionatoria del Estado reside en la facultad con la que este ente jurídicopolítico soberano, y legítimo monopolizador de la fuerza y del dominio legal de las armas atribuidas a su imperio, juzga, condena o absuelve a sus asociados debido a la comisión de alguna conducta penada (Weber, 2002). En tal sentido el Estado actúa como soberano dotado de la capacidad de administrar los castigos y las penas a quienes alteren las normas de convivencia social (Ambos, 2013). Dicho principio se denomina lus Pudiendi y el mismo hace parte de la naturaleza propia del derecho penal en las sociedades contemporáneas. En tal virtud, el Estado también determina los objetivos de la política criminal, puesto que la misma brinda los parámetros para conducir la comisión de conductas punibles a la adecuada convivencia social por parte de los infractores. La Justicia Transicional es entonces una parte de la Política Criminal del Estado y la misma 
conduce a quienes están alzados en armas en contra de la Soberanía Estatal a reintegrarse en la sociedad bajo la tutela del Estado y sus instituciones. (Ambos, 2008)

Es importante resaltar que esta capacidad atribuida a la soberanía estatal para imponer el castigo al titular del delito está limitada por los derechos y las prerrogativas de los ciudadanos, es decir, este derecho o capacidad del Estado en modo alguno es ilimitada (Orellana, 2003). La capacidad del Estado de imponer penas y de privar derechos es una capacidad inherente a su vida y funcionamiento, de forma tal que las limitaciones a este están dadas en términos generales por las demarcaciones que imponen las sociedades democráticas, en Colombia, para citar solo un ejemplo se encuentran expresamente prohibidas por la Carta Política, tanto las penas de prisión perpetua y la pena de muerte (C 565/93 Corte Constitucional de Colombia, 1993). Pero no solo tales limitaciones existen en materia de la efectiva restricción a la capacidad sancionatoria del Estado.

Existen también límites impuestos por el surgimiento de la legislación internacional en materia de protección de derechos humanos. En especial los tratados que le dan vida y operatividad a la CIDH o Pacto de Costa Rica y a la CPI o Estatuto de Roma (Werle, 2011). Estos tratados constituyen una forma de ceder una parte de la capacidad nacional en materia de juzgamiento e imposición de penas a los infractores y delincuentes especialmente en relación con conflictos armados, gracias a que en primer lugar establece estándares penales de orden internacional, que de no observarse pueden activar la competencia de los tribunales externos y en segundo lugar, porque los mismos, 
tienen insertos los principios de subsidiariedad y complementariedad de la acción penal soberana del Estado que acepta su competencia eventual (Avila, 2014).

Sin lugar a dudas, uno de los desarrollos más importantes del derecho internacional en los últimos años ha sido la creación de la Corte Penal Internacional (CPI), la cual constituye el mecanismo judicial internacional de mayor trascendencia en la protección de los derechos humanos y el derecho internacional humanitario 10. En esta medida, según lo dispone el preámbulo del Estatuto de Roma (ER), la finalidad esencial de la CPI consiste en que "los crímenes más graves de trascendencia para la comunidad internacional en su conjunto no deben quedar sin castigo y que, a tal fin, hay que adoptar medidas en el plano nacional e intensificar la cooperación internacional para asegurar que sean efectivamente sometidos a la acción de la justicia" (Rettberg, 2005a, p.9)

El propósito de este capítulo es analizar conceptos como Justicia Transicional desde el punto de vista del derecho internacional público, la Ley 975 de 2005, su origen, propósitos y sus fines con relación a las víctimas del conflicto armado (Justicia, Verdad, Reparación y No Repetición); así como también examinar los problemas en su aplicación, que en dado caso podrían activar la competencia de un tribunal internacional externo por encima de la soberanía estatal colombiana. 


\subsection{Justicia Transicional y límites a la capacidad punitiva del Estado}

"A diferencia de lo que en general se cree, "justicia transicional" no es sinónimo de "comisión de la verdad y reconciliación". Aunque no exista un modelo único establecido-de hecho un informe reciente de Naciones Unidas advierte que debemos aprender a no recurrir a fórmulas únicas, iguales para todos, y a no importar modelos extranjeros-la justicia transicional se entiende cada vez más como un paradigma jurídico que consta de cuatro mecanismos o componentes: (1) Acciones judiciales contra los autores individuales de crímenes (ya sea por medio de tribunales nacionales o internacionales). (2) La promoción de iniciativas de búsqueda de la verdad para esclarecer abusos pasados y construir la memoria histórica (comisiones de la verdad, entidades investigadoras). (3) La reparación, tanto material, como inmaterial, de las víctimas de violaciones de derechos humanos. (4) La reforma inmediata de instituciones importantes para la gobernabilidad democrática (incluyendo la investigación de antecedentes, la remoción de los culpables de sus cargos y su exclusión de los puestos públicos)." (Rettberg, 2005b, p.9)

Tenemos entonces que la denominada justicia transicional, es una forma de limitar las competencias sancionatorias del Estado. La justicia de transición es una forma de limitar In Extremis la facultad estatal para imponer castigos a quienes vulneren las normas y estatutos definidos por la facultad sancionatoria del Estado. La denominada justicia transicional resulta ser entonces, una justicia de excepción, excepción de la aplicación de las normas penales que tiene por propósito central, exceptuar las mismas en forma temporal para conseguir o salvaguardar el bien jurídico de la paz (Uprimny, 2006a). Por tal motivo los procesos de paz, en las tres últimas décadas en Colombia, se han basado en este principio jurídico político, principio, que en la práctica significa la restricción del 
poder soberano del Estado de aplicar justicia por medio de la imposición de severas penas y restricciones de bienes jurídicos individuales a sujetos no funcionales que vulneran los códigos de conducta socialmente aceptable, expresada en normas y códigos legítimos (Lombana, 2005).

En palabras de Sania Romeike, "el término se utilizó por primera vez en los años noventa, una época de transformación global post-guerra fría, emergiendo a partir del movimiento a favor de los derechos humanos y su concepción original se enfocaba en la penalización legal de los crímenes contra los derechos humanos cometidos por los regímenes dictatoriales o represivos del pasado. Durante las últimas dos décadas aparte de generar un marco considerable de trabajo académico, la idea ha sido progresivamente apropiada y extendida por las organizaciones internacionales y las comunidades de construcción de paz y derechos humanos, al mismo tiempo que su significado se ha expandido a una gran variedad de instrumentos, mecanismos y medidas que van más allá de lidiar con el pasado de una manera simplemente punitiva" (2016).

De otro lado, puede afirmarse que el surgimiento de la justicia transicional, afecta de manera ostensible la soberanía estatal, por cuanto la aplicación de normas laxas en materia penal, inscritas en la política de justicia transicional, afecta los compromisos internacionales del Estado con los tribunales que juzgan la violación de graves infracciones a los derechos humanos y al Derecho Internacional Humanitario, lo que en el caso de la Corte Interamericana de Derechos Humanos (CIDH) puede acarrearle condenas al Estado y en el caso de la CPI puede activar su competencia Subsidiaria y 
Complementaria tendiente a complementar su acción penal interna (Wolffughel, 2011a). Nos ocuparemos entonces de examinar este segundo aspecto, gracias a que este, puede significar que los propósitos que persigue el proceso de desmovilización y reinserción de las organizaciones criminales inserto en la Ley 975 de 2005, a saber, grupos paramilitares y otros que hicieron parte de manera voluntaria del mismo, den al traste con la hegemonía de las normas penales y por consiguiente afecten de manera sistemática la capacidad sancionatoria legítima del Estado, y los compromisos internacionales de este, en especial con la CPI.

\subsection{La Justicia Transicional y la Ley 975 de 2005}

"En julio de 2005, el Congreso de la República aprobó la Ley 975 o Ley de Justicia y Paz, con el objeto de "facilitar los procesos de paz y la reincorporación individual o colectiva a la vida civil de miembros de grupos armados al margen de la ley, garantizando los derechos de las víctimas a la verdad, la justicia y la reparación" (Art. 1ㅜ, Ley 975). Con ella se buscó generar un marco legal para la regulación de lo concerniente "a la investigación, procesamiento, sanción y beneficios judiciales de las personas vinculadas a grupos armados organizados al margen de la ley, como autores o partícipes de hechos delictivos cometidos durante y con ocasión" de su pertenencia a esos grupos, y que hubieren decidido desmovilizarse y contribuir a la reconciliación nacional (Art. $2^{\circ}$, Ley 975)." Nalencia, Germán \& Mejía, Carlos, 2010a. Ley de Justicia y Paz. Un balance de su primer lustro. Perfil de Coyuntura Económica - Universidad de Antioquia. Volumen No. 15, p. 59-77) 
La aplicación de la ley 975 de 2005 está basada en una concepción maximalista de juzgamiento global de todas las conductas ocurridas en el marco de la confrontación con las agrupaciones paramilitares en Colombia y con los miembros de otros grupos que deseen sumarse al proceso de cese definitivo de hostilidades (Uprimny, 2006b). Tal situación generó un desbordamiento de la capacidad del Estado para cumplir los ambiciosos propósitos insertos en este instrumento legal. Más de una década después de la entrada en vigor de la ley, el nivel de condenas y de actos de reparación a las víctimas sigue siendo precario, razón por la que el incumplimiento de los estándares de justicia, verdad y reparación siguen siendo altos en relación con las obligaciones del Estado Colombiano en el acatamiento de los mismos a la luz de los distintos instrumentos internacionales de los que este hace parte (Contraloría General de la República , 2017). Esta situación en específico hace que exista el serio riesgo de que la CPI pueda activar su competencia residual para juzgar a los responsables individuales de crímenes contra DIH a partir de su competencia temporal y material en virtud de la aplicación efectiva del principio de complementariedad, base de la estructura orgánica del Estatuto de Roma y de la CPI (Quesada Alcalá, 2005).

El derecho internacional que rige las relaciones de quienes forman parte de la comunidad internacional y el derecho interno, propio de cada uno de estos sujetos jurídicos soberanos, operan bajo la lógica de la primacía de la soberanía interna de los estados sobre la supremacía de las normas internacionales, por ello las posiciones doctrinales en la materia, tratan entonces de saber si existen o no relaciones entre estos ámbitos jurídicos diversos y, en caso de que existan, determinar cuál de los ámbitos tiene 
primacía (Olásolo, 2015a). En primer lugar, se encuentra la posición del dualismo, este enfoque plantea que el derecho internacional y el derecho interno son nociones diferentes y aún opuestas, en su contenido jurídico el derecho internacional regula relaciones entre estados iguales, mientras que el ordenamiento interno reglamenta relaciones internas entre particulares súbditos de un Estado. En cuanto al fundamento jurídico, se señala que uno se basa en la voluntad de varios estados que se encuentran en relación de coordinación, mientras que el interno se basa en la voluntad soberana de un solo Estado (Monroy, 2010a).

Las consecuencias de tal posición son entre otras que, los tratados internacionales establecen obligaciones positivas al Estado aun cuando estos no afecten de manera directa la vida de los asociados. De forma tal que como el derecho internacional no puede alcanzar directamente a los individuos requiere ser transformado en derecho interno que lo desarrolle (Arango, M., 2004a. El bloque de constitucionalidad en la jurisprudencia de la Corte Constitucional colombiana. Precedente. Revista Jurídica, p. 79-102).

Por otro lado, se halla el monismo, este surge, como posición contraria y plantea que el derecho interno y el derecho internacional conforman un solo sistema jurídico, de la misma forma el monismo con primacía del derecho interno (monismo constitucionalista) sostiene que el derecho de gentes solo tiene validez si está acorde con el ordenamiento nacional. De otro lado, existe una visión más radical del monismo que sugiere que el derecho interno debe adecuarse al derecho internacional, así pues, la convención de 
Viena de 1969 sobre el derecho de los tratados será considerada como monista (Monroy, 2010b).

Las normas del Derecho Internacional Humanitario, empezando por los cuatro convenios de Ginebra 1949 y sus tres protocolos adicionales de 1979, son de manera fundamental los principios de carácter general sobre los cuales las legislaciones internas, deben trabajar para hacer normativa y fácticamente exigibles las disposiciones atinentes a los tipos penales de las legislaciones internas, y hacer exigibles los preceptos que rigen el comportamiento jurídicamente aceptable en el marco de las confrontaciones bélicas, sean estas de orden internacional o interno. En el Sistema Interamericano de Protección de Derechos Humanos de la OEA, Colombia es el segundo Estado parte más condenado en el sistema con 16 sentencias en contra que ordenan entre otras cuantiosas reparaciones con arreglo a los recursos del tesoro público (Faúndez Ledesma, 2004).

Existe un derecho internacional que rige las relaciones de quienes forman parte de la comunidad internacional y un derecho interno propio de cada uno de estos sujetos internacionales, se trata entonces de saber si existen o no relaciones entre estos ámbitos jurídicos diversos y, en caso de que existan, determinar cuál de los ámbitos tiene primacía. Posición del dualismo: este enfoque plantea que el derecho internacional y el derecho interno son nociones diferentes y aún opuestas, en su contenido jurídico el derecho internacional regula relaciones entre estados iguales, mientras que el ordenamiento interno reglamenta relaciones internas entre particulares súbditos de un Estado (Olásolo, 2015b). En cuanto al fundamento jurídico, se señala que uno se basa 
en la voluntad de varios Estados que se encuentran en relación de coordinación, mientras que el interno se basa en la voluntad soberana de un solo Estado. Para el caso particular de Colombia, en materia de protección de los derechos humanos, todos los tratados internacionales cuya materia sea esta, y que hayan sido formalmente ratificados hacen parte de la constitución política, esto se denomina: Bloque de Constitucionalidad (Arango, 2004b).

\subsection{Problemas de aplicación de las normas de Justicia Transicional en Colombia}

La legislación vigente en Colombia centrada en los postulados de la denominada Justicia Transicional, han estado desarrollados fundamentalmente sobre la base de permitir un marco general de reintegración a la vida civil de miembros de Grupos Armados Organizados al Margen de la Ley, en la Ley 975 de 2005 e implementar un proceso de reparación integral y restitución de tierras, Ley 1448 de 2011, conexos con estas dos leyes existe un abigarrado mosaico de decretos que desarrollan temas específicos de las mismas. Sin embargo ambas tienen la seria dificultad de que fueron implementadas sin que la confrontación bélica hubiese cesado, es decir que la excepcionalidad en que se centraba su surgimiento y aplicación, continuó estando cifrada en la realidad conflicto, lo que resultó enteramente problemático porque ello no permitió superar las situaciones objetivas de victimización ni garantizar para el caso de la Ley de Restitución de Tierras los procesos de retorno y reintegración de predios, a su vez, también impidió diagnosticar la magnitud del problema de atención integral de víctimas, ni permitió precisar el número o la tipología de atención que el Estado debía implementar, puesto que el número de 
víctimas continuaba creciendo exponencialmente entre tanto se desarrolla la confrontación militar (Garay Salamanca, 2013a).

En la experiencia comparada los procesos de Pos Acuerdo se acompaña y desarrollan en conexidad de una política de restitución material de los derechos de las víctimas y de los combatientes reintegrados a la vida civil, es decir, que las víctimas puedan retornar a sus formas de vida en condiciones similares a las que tenían previamente a la ocurrencia de los hechos victimizantes, acompañado de medidas efectivas que garanticen la no repetición, con facultades de uso pleno y goce efectivo de sus derechos por las autoridades competentes (Mcausland, 2010a). Además, la reparación debe estar acompañada de acciones orientadas a garantizar el derecho a la educación, formación, salud, seguridad y en especial a la esperanza de vivir en una sociedad en paz, donde se gesten reales procesos de reconciliación y se garanticen derechos a la verdad, justicia, reparación y acciones de no repetición (Mcausland, 2010b).

El conflicto armado ha generado graves afectaciones a las personas que han sido víctimas de las manifestaciones de violencia en desarrollo de este fenómeno, en especial, aquellas que desarrollaban su vida cotidiana en territorios rurales, tal realidad les generó una inseguridad jurídica respecto de la protección de Derechos fundamentales y demás garantías establecidas en normas nacionales e internacionales. Por ello, esta situación de desprotección solo sería superada tras la cesación efectiva y definitiva el conflicto armado y con ello, todos los tipos de hostilidades que afectaban a la población civil (Alcaldía Mayor de Bogotá, 2012). 
Como consecuencia de este marco de vulneración de derechos, desprotección generalizada del Estado e ineficacia del mismo para garantizar la seguridad a los ciudadanos que habitan el territorio Nacional, se evidenció el desarrollo de una profunda crisis humanitaria y la ocurrencia de gravísimos hechos victimizantes. Las familias de muchas zonas rurales, tuvieron que abandonar sus tierras o fueron despojadas de éstas, gracias a la acción criminal de los grupos paramilitares, en su mayoría, viéndose obligadas a iniciar nuevos proyectos de vida en las grandes ciudades del país como Bogotá y otras capitales, hecho que generó que muchas de estas vivieran en condiciones de extrema pobreza y experimentaran serias dificultades para adaptarse a otras culturas, costumbres y a entornos urbanos agrestes, de violencia y segregación, además ello trajo como consecuencia que se forzaron al máximo los programas de ayuda y atención prioritaria de las grandes ciudades que como Bogotá no han dado abasto para atender tales necesidades. En medio de esta realidad, tanto la Ley 975 como la Ley 1448 instituyeron el registro de víctimas, y ambas actuaron de manera conjunta para establecer el marco de las reparaciones que les eran atribuibles a los miembros de estas organizaciones desmovilizadas.

\subsection{Elementos de contexto jurídico y de derechos de las víctimas}

Colombia como un Estado Social de Derecho establecen jurídicamente la armonía entre las diferentes normas nacionales e internacionales en materia de protección y garantía 
de los Derechos Humanos por medio de la acción del Bloque de Constitucionalidad (Uprimny, 2008). A su vez, dentro de los fines del Estado se identifica la garantía de la seguridad nacional, derecho que debe permear a cada uno de los ciudadanos colombianos y sus instituciones deben orientar sus acciones en pro del reconocimiento de la dignidad humana, prevenir toda clase de conflictos que lleguen a perturbar la paz y convivencia pacífica en la sociedad.

En la Constitución de 1991 el Estado Colombiano adquirió deberes y obligaciones para la adecuada garantía de derechos inherentes al hombre, no obstante, la realidad ha mostrado que el cumplimiento de los derechos de la Carta es aún muy precario, mucho más, con el desarrollo de un conflicto armado en el cual se han vulnerado derechos y premisas elementales de salvaguarda de la dignidad humana, además de las más graves violaciones del Derecho Internacional de los Derechos Humanos y del Derecho Internacional Humanitario. En este sentido, es necesario tener en cuenta que la normatividad Internacional al evidenciar la ocurrencia de estos hechos se orienta a establecer normas y recomendaciones para que se mitiguen los impactos generados por los mismos y para que los Estados garanticen los derechos de los ciudadanos. En este sentido, la obligación del Estado en materia de reparación a las víctimas del conflicto encuentra su justificación en el Derecho Internacional de los Derechos Humanos que protege a la población civil que puede verse afectada por un conflicto interno, específicamente en la Jurisprudencia sobre la materia emanada de la Corte Interamericana de Derechos Humanos².

\footnotetext{
2 Al respecto es conveniente revisar las siguientes sentencias de la Corte Interamericana de Derechos Humanos. Corte Interamericana de Derechos Humanos. Masacre de Pueblo Bello Vs Colombia. Corte
} 
En este marco, y siguiendo los preceptos internacionales e internos, el gobierno nacional expidió en 1997 la Ley 387 "por la cual se adoptan medidas para la prevención del desplazamiento forzado; la atención, protección, consolidación y esta estabilización socioeconómica de los desplazados internos por la violencia en la República de Colombia", la cual buscaba aceptar la ocurrencia del conflicto armado en Colombia y las consecuencias del mismo en los ciudadanos, es decir, en aquellas personas, hombres, mujeres, niños, indígenas, afro descendientes, que a raíz de esta situación se han visto obligados a abandonar su lugar de origen. Esta ley fue el inicio para el reconocimiento de los derechos de las víctimas del conflicto armado, así como el inicio de la realización de acciones para prevenir este fenómeno además de proteger a las personas que lo han padecido. Posteriormente el gobierno nacional con la persistencia y la continuidad del conflicto armado y la realidad que viven las víctimas de este flagelo adoptó la Ley 975 de 2005, como un esfuerzo encaminado hacia la búsqueda de la desmovilización de grupos armados al margen de la ley, reparación para las víctimas del conflicto armado. Posteriormente y frente a los problemas generados por la aplicación de la Ley 975 de 2005 y sus normas reglamentarias, y por la continuidad de las consecuencias derivadas del conflicto armado colombiano, se gestó en el Congreso de la República durante la segunda legislatura del año 2010, el trámite de una ley que garantizaría materialmente los derechos de la víctimas del conflicto armado (no obstante la continua oposición del entonces gobierno nacional al término en cuestión) en la que se reconocieran los efectos

\footnotetext{
Interamericana de Derechos Humanos Sentencia 31 de enero de 2006. Masacre de Mapiripán Vs Colombia. Corte Interamericana de Derechos Humanos. 15 de septiembre de 2005, Masacre de Ituango Vs Colombia. Corte Interamericana de Derechos Humanos. 1 de julio de 2006.
} 
de este fenómeno y las implicaciones que el mismo generaba en los ciudadanos colombianos, además de intentar establecer mecanismos y procedimientos para la reparación integral y efectiva de las víctimas, y también como respuesta a la declaratoria de estado de cosas inconstitucional que la Corte Constitucional había declarado en relación con la población desplazada en la Sentencia T 025 de 2004 y a las órdenes impartidas al gobierno que se derivaron de ello.

Así, de la Ley de Justicia y Paz emanaron cuatro máximas fundamentales en favor de las víctimas, verdad, justicia, reparación y no repetición; el derecho a la verdad de las víctimas comprende el conocimiento de los delitos, las circunstancias y los autores materiales e intelectuales de estas terribles conductas. La justicia implica que se lleve a cabo la investigación y juzgamiento de los hechos delictivos y se imponga la pena alternativa siempre que los postulados hayan contribuido a la reparación integral de las víctimas de manera material, simbólica y moral a través de la restitución de sus derechos, indemnización de los daños, rehabilitación física, social, sicológica, medidas de satisfacción y de garantías de no repetición de los hechos violentos (Valencia Germán, Mejía Carlos, 2010b).

Así las cosas, como resultado de la confrontación bélica que ha azotado a Colombia por décadas, con la emisión de la Ley 975 de 2005 se precisa un esfuerzo estatal por resolver el conflicto armado y reivindicar a las víctimas, pero no desde el punto de vista militar, sino desde la razón y el diálogo, a partir del sometimiento de los miembros de grupos armados al margen de la Ley a cambio de beneficios y garantías; proceso que se 
enmarca dentro del concepto de Justicia Transicional para encarar las graves y sistemáticas vulneraciones que el sistema judicial tradicional no había podido resolver, esto sin olvidar que Colombia hace parte de un sistema de principios y reglas de carácter internacional, en virtud del Bloque de Constitucionalidad, lo cual permite que la comunidad mundial esté al tanto de las resultas del proceso y también provea herramientas jurídicas en caso de la imposibilidad o falta de voluntad del Estado de investigar y juzgar los hechos cometidos con ocasión del conflicto.

\section{CAPÍTULO II}

\section{ELEMENTOS CONTEXTUALES DEL ESTANDAR INTERNACIONAL DE REPARACIÓN}

Este capítulo tiene por objeto verificar el estado actual de obligaciones de Colombia en materia de Justicia Penal Internacional enmarcadas en el DIH, así como de los elementos exigidos en el marco del DIDH, en particular en Sistema Interamericano de Protección de Derechos Humanos, respecto de los procesos de justicia transicional, a fin de elucidar elementos en materia de justicia que garanticen el cumplimiento de los estándares internacionales en el marco del proceso de paz desarrollado entre el Gobierno Nacional y los grupos armados ilegales en el marco de la Ley de Justicia y Paz, Paramilitares y miembros individuales de otras organizaciones delictivas, en particular, frente a la 
posibilidad o no de brindar tratos laxos a los delitos internacionales más graves cometidos en el marco del conflicto armado interno, y con ello violar el estándar internacional de justicia y por su conducto activar eventualmente la competencia residual de la CPI en Colombia.

Se tiene como propósito determinar los principios sobre verdad y reparación que se han promulgado por uno de los máximos organismos internacionales para la búsqueda de la paz mundial, la ONU; entender también conceptos básicos como Conflicto Armado No Internacional, lo cual para el caso colombiano propondría unos estándares mínimos humanitarios en el trato de las víctimas, por parte del Estado y los perpetradores, así como obligaciones a este último al momento de impartir justicia en el marco de un proceso de Justicia Transicional desarrollado en virtud de un acuerdo de paz y de

desmovilización. Por otro lado, se resaltará el importante desarrollo jurisprudencial de la Corte Constitucional acerca del cumplimiento del estándar internacional de reparación que suscita el conflicto colombiano con ocasión de la Ley 975 y sus decretos reglamentarios.

\subsection{Máximas internacionales sobre verdad y reparación}

La búsqueda de la verdad de cara a la sanción de los victimarios, y la consecuente reparación de las víctimas se han convertido en axiomas del derecho internacional como reconocimiento del sufrimiento de las víctimas de vejámenes en sus derechos humanos y los deberes estatales que surgen a raíz de esas situaciones; en virtud de ello en el año 
2005, se aprobaron y divulgaron dos grupos de principios por la Comisión de Derechos Humanos de la Organización de las Naciones Unidas: i) el "Conjunto de principios actualizado para la protección y promoción de los derechos humanos mediante la lucha contra la impunidad", y ii) "Los principios y directrices básicos sobre el derecho de las víctimas de violaciones manifiestas de las norma internacionales de derechos humanos $y$ de violaciones graves del derecho internacional humanitario a interponer recursos $y$ obtener reparaciones", también llamados principios Louis Joinet en honor al Magistrado de origen francés autor del informe contra la impunidad que motivara las resoluciones de la ONU al respecto.

En palabras de la Comisión Colombiana de Juristas en el ejercicio de compilar los instrumentos internacionales en mención, los principios de lucha contra la impunidad se constituyen:

"a partir de la obligación general de prevenir, investigar y sancionar las violaciones de derechos humanos, una serie de enunciados derivados del marco jurídico vigente. Estos principios se organizan en torno a tres grandes categorías: el derecho a saber (o el derecho a la verdad); el derecho a la justicia; y el derecho a obtener reparaciones. Los principios no enuncian normas nuevas ni generan obligaciones que no hayan sido preexistentes; sencillamente, organizan o sistematizan los derechos y las obligaciones existentes en función de la lucha contra la impunidad. 
Este nuevo instrumento de derecho internacional de los derechos humanos reafirma, de manera específica y concentrada, las obligaciones existentes que tienen todos los Estados en materia de lucha contra la impunidad. Su sustento vinculante radica en que todos los enunciados tienen respaldo en distintas fuentes del derecho internacional público vigente (tratados, costumbre, principios generales de derecho, jurisprudencia y doctrina)." (CCJ, 2007, p.18)

Y, por otro lado, con relación al derecho de reparación de las víctimas las misma CCJ, indicó:

"De acuerdo al derecho internacional, la violación de cualquier derecho implica el deber de reparar a las víctimas. La reparación tiene como objeto aliviar el sufrimiento de la víctima y, en la medida de lo posible, restablecer el statu quo ante. La obligación también la recoge el principio in integrum restitutio. En el marco del derecho internacional de los derechos humanos, el derecho a obtener reparaciones goza de respaldo explícito en múltiples tratados. Está contemplado en el derecho genérico a un recurso efectivo12 y también en disposiciones específicas y tratados específicos que exigen la reparación de manera directa." (CCJ, 2007, p.19.).

Lo que se extracta de ello es que la verdad entendida como derecho está compuesta por un serio compromiso del Estado y de las autoridades judiciales en la búsqueda de la verdad como un derecho esencial para las víctimas. Tal compromiso debe tener tres componentes estructurales, son ellos: el derecho de las victimas a conocer la verdad 
acerca de las violaciones derechos humanos de que fueron objeto, a su vez, las victimas también tienen el derecho a que esta verdad se desarrolle de manera pública, ello con el ánimo de evitar situaciones de repetición de los hechos victimizantes y por último el derecho a la verdad como una garantía de orden individual a conocer las circunstancias de modo tiempo y lugar en la que fueron cometidos las violaciones de derechos humanos. (Estandares internacionales en materia de reparaciòn a las victimas. Su devenir y ejecuciòn en el conflcito colombiano, 2013). En este mismo sentido se pronunció la Corte Constitucional en la sentencia C - 454 de 2006 en la que definió el alcance de los derechos de las víctimas [...] el conjunto de principios para la protección y la promoción de los derechos humanos mediante la lucha contra la impunidad (principios $1^{\circ}$ a 4). Se incorporan en este derecho las siguientes garantías: (i) el derecho inalienable a la verdad, (ii) el deber de recordar, (iii) el derecho de las víctimas a saber " (Corte Constitucional de Colombia , 2006)

En segundo lugar, se encuentra el derecho de las víctimas de acceso a la Justicia. Para el relator de la ONU la naturaleza amplia y axiológicamente diversa del concepto de justicia se materializa en materia de justicia transicional como el derecho que reside en cabeza de las víctimas a tener acceso a la garantía de sus derechos mediante el desarrollo de un proceso judicial justo y eficaz. La dimensión general de la aplicación de este derecho se expresa en dos dimensiones concomitantes, de un lado cuando a las víctimas se les da la opción de perdonar luego de la solicitud del victimario y en segundo cuando en el transcurso del proceso las victimas tienen acceso a la reparación por los daños contra ellos cometidos. También la sentencia de la Corte Constitucional precisó 
para el caso colombiano el alcance de este derecho en la sentencia C - 454 de 2006. En último término se encuentra el derecho a la reparación integral que se halla descrito en el principio 36 del conjunto de principios para la promoción de los derechos humanos ONU - 2006, en el sentido de desarrollar medidas que tiendas a hacer desaparecer los efectos de las vulneraciones de derechos humanos padecidas por las victimas $(\mathrm{CIDH}$, 2003). Al respecto sostiene la CIDH: "El derecho a la reparación deberá abarcar todos los daños y perjuicios sufridos por la víctima; comprenderá por una parte medidas de satisfacción de alcance general, como las previstas en el conjunto de principios y directrices fundamentales sobre el derecho a obtener reparación" (Corte IDH, 2002).

Bajo este panorama generado por la sistemática vulneración del DIH y del DIDH en nuestro país, resulta necesario mencionar brevemente los principios internacionales sobre la lucha contra la impunidad y los principios internacionales sobre el derecho de las víctimas a obtener reparaciones aprobados por la ONU, para determinar si se encuentran insertos en nuestro sistema de Justicia y Paz, y si el Estado ha cumplido con las obligaciones que emanan de los mismos. (El derecho internacional humanitario principio de una educaciòn hacia la paz, 2006). Al respecto la CCJ ha hecho una completa compilación de estos, en el siguiente listado:

\section{Cuadro. 1 estándares y principios internacionales en materia de Justicia, Verdad y Reparación}

\begin{tabular}{|l|l|}
\hline I. & Lucha contra la impunidad: Obligaciones generales \\
\hline & $\begin{array}{l}\text { Principio 1. Obligaciones generales de los Estados de adoptar medidas eficaces para } \\
\text { luchar contra la impunidad }\end{array}$ \\
\hline
\end{tabular}




\begin{tabular}{|c|c|}
\hline II. & Derecho a saber \\
\hline & A. Principios generales \\
\hline & $\begin{array}{l}\text { Principio 2. El derecho inalienable a la verdad } \\
\text { Principio 3. El deber de recordar } \\
\text { Principio 4. El derecho de las víctimas a saber } \\
\text { Principio 5. Garantías para hacer efectivo el derecho a saber-Comisiones de } \\
\text { investigación }\end{array}$ \\
\hline & B. Comisiones de investigación \\
\hline & $\begin{array}{l}\text { Principio 6. Establecimiento y función de las comisiones de la verdad } \\
\text { Principio 7. Garantías de independencia, imparcialidad y competencia } \\
\text { Principio 8. Delimitación del mandato de una comisión } \\
\text { Principio 9. Garantías relativas a las personas acusadas } \\
\text { Principio 10. Garantías relativas a las víctimas y a los testigos que declaran a su } \\
\text { favor Principio 11. Recursos adecuados para las comisiones } \\
\text { Principio 12. Función de asesoramiento de las comisiones } \\
\text { Principio 13. Publicidad de los informes de las comisiones }\end{array}$ \\
\hline & C. Preservación y consulta de los archivos a fin de determinar las violaciones \\
\hline & $\begin{array}{l}\text { Principio 14. Medidas de preservación de los archivos } \\
\text { Principio 15. Medidas para facilitar la consulta de los archivos } \\
\text { Principio 16. Cooperación de los servicios de archivo con los tribunales y las } \\
\text { comisiones extrajudiciales de investigación } \\
\text { Principio 17. Medidas específicas relativas a los archivos de carácter nominativo } \\
\text { Principio 18. Medidas específicas relativas a los procesos de restablecimiento de } \\
\text { la democracia y/o de la paz o de transición hacia ellas Impunidad }\end{array}$ \\
\hline$m$. & Derecho a la justicia \\
\hline & $\begin{array}{l}\text { A. Principios generales } \\
\text { Principio 19. Deberes de los Estados en materia de administración de la justicia } \\
\text { B. Delimitación de competencias entre las jurisdicciones nacionales, extranjeras, } \\
\text { internacionales e internacionalizadas } \\
\text { Principio 20. Competencia de los tribunales penales internacionales e } \\
\text { internacionalizados Principio 21. Medidas para reforzar la eficacia de los principios } \\
\text { jurídicos internacionales relativos a la competencia universal e internacional }\end{array}$ \\
\hline
\end{tabular}


C. Medidas restrictivas incorporadas a determinadas normas del derecho que se justifican por la lucha contra la impunidad

Principio 22. Carácter de las medidas restrictivas

Principio 23. Restricciones a la prescripción

Principio 24. Restricciones y otras medidas relativas a la amnistía

Principio 25. Restricciones al derecho de asilo Principio

26. Restricciones a la extradición/non bis in idem

Principio 27. Restricciones a las justificaciones que puedan vincularse a la obediencia debida, la responsabilidad superior y el carácter oficial

Principio 28. Restricciones a los efectos de las leyes sobre divulgación o sobre arrepentidos Principio 29. Restricciones a la competencia de los tribunales militares

Principio 30. Restricciones al principio de inamovilidad de los jueces

IV. Derecho a obtener reparación/garantías de que no se repitan las violaciones

A. Derecho a obtener reparación

Principio 31. Derechos y deberes dimanantes de la obligación de reparar

Principio 32. Procedimientos de reparación

Principio 33. Publicidad de los procedimientos de reparación

Principio 34. Ámbito de aplicación del derecho a obtener reparación

$B$. Garantías de no repetición de las violaciones

Principio 35. Principios generales

Principio 36. Reforma de las instituciones estatales

Principio 37. Desmantelamiento de las fuerzas armadas para estatales desmovilización y reintegración social de los niños

Principio 38. Reforma de las leyes e instituciones que contribuyen a la impunidad ..." (CCJ, 2007, p. 34-35)

Comisión Colombiana de Juristas. CCJ. 2007

\subsection{Conflicto Armado no Internacional y Estándar Internacional de Justicia}


Según el marco de obligaciones internacionales del Estado Colombiano se puede satisfacer el estándar de verdad, si se determina en las sentencias de Justicia y Paz la identificación de los más altos responsables de los crímenes, se logra determinar las estructuras verticales (mando militar) y horizontales (redes, financiadores, cooperantes, etc.), del aparato organizado de poder, los patrones de los crímenes de manera regionalizada y nacional, la división del trabajo criminal, la fungibilidad de los miembros de la estructura, entre otros. Así mismo, el estándar de justicia se satisface cuando existe la efectiva sanción a los responsables de cara a los fines de la pena, la validación de los hechos aportados por los postulados en sus versiones por parte de la Fiscalía y si se compulsó copias para investigar a militares, políticos (autoridades administrativas) y empresarios involucrados en la comisión de crímenes.

De la definición de si en Colombia estamos frente a un CANI (Conflicto Armado No Internacional) o no, emanan consecuencias jurídicas que trascienden el plano nacional, por ello este debate, aunque parezca irrelevante, es el punto de partida para abordar las obligaciones contraídas en el marco del DIH y del DIDH y sus implicaciones frente a los derechos de las víctimas. La existencia de un conflicto armado (CANI) es un hecho objetivo, esto es, depende de que los hechos correspondan con la definición que el DIH establece, de manera que se deshecha cualquier carga subjetiva producto de la valoración de los actores políticos. El corpus juris del DIH define objetivamente la existencia de un conflicto armado en varios documentos, siendo los más importantes el artículo 3 común de los Convenios de Ginebra de 1949 y el artículo 1 del Protocolo II adicional a los Convenios de Ginebra relativo a la protección de las víctimas de los 
conflictos armados sin carácter internacional de 1977. Respecto al artículo 3 común, el CICR, Comité Internacional de la Cruz Roja, ha señalado:

"El artículo 3 común se aplica a un "conflicto armado que no sea de índole internacional y que surja en el territorio de una de las Altas Partes Contratantes". Puede ser un conflicto armado en que participen uno o más grupos armados no gubernamentales. Según la situación, puede haber hostilidades entre las fuerzas armadas gubernamentales y grupos armados no gubernamentales o entre esos grupos únicamente. Dado que los cuatro Convenios de Ginebra han sido ratificados universalmente, el requisito de que el conflicto armado ocurra "en el territorio de una de las Altas Partes Contratantes" ha perdido su importancia en la práctica. De hecho, cualquier conflicto armado entre fuerzas armadas gubernamentales y grupos armados o entre estos grupos sólo puede tener lugar en el territorio de una de las Partes en el Convenio" (Articulo 3 Común a los cuatro Convenios de Ginebra).

Por su parte el artículo 1 del protocolo II adicional define los CANI como aquellos que:

"...se desarrollen en el territorio de una Alta Parte contratante entre sus fuerzas armadas y fuerzas armadas disidentes o grupos armados organizados que, bajo la dirección de un mando responsable, ejerzan sobre una parte de dicho territorio un control tal que les permita realizar operaciones militares sostenidas $y$ concertadas y aplicar el presente Protocolo." ("Protocolo II adicional a los Convenios de Ginebra de 1949 relativo a la protección de las víctimas de los conflictos armados sin carácter internacional, 1977"). 
Los criterios objetivos esenciales de esta definición han sido acogidos por el DIH con base en las decisiones emitidas por el Tribunal Penal Internacional para la Antigua Yugoslavia y se resumen en "(i) la intensidad del conflicto y (ii) la organización de las partes". Estos criterios son, si se quiere, los mínimos esenciales en los que coinciden ambos instrumentos del $\mathrm{DIH}$, al punto en que el artículo 8.2.f del Estatuto de Roma hace alusión solo a estos elementos mínimos para el reconocimiento de un CANI en los siguientes términos: "Se aplica a los conflictos armados que tienen lugar en el territorio de un Estado cuando existe un conflicto armado prolongado entre las autoridades gubernamentales y grupos armados organizados o entre tales grupos" (Estatuto de Roma de la Corte Penal Internacional, 1998).

El CANI, se diferencia del CAI, fundamentalmente por la calidad de los sujetos en conflicto, es decir, mientras que en el CAl se enfrentan dos o más Estados, o pueblos que luchan contra el colonialismo o la dominación extranjera, en el CANI se enfrenta un Estado contra grupos alzados en armas en su territorio, o el enfrentamiento es entre éstos grupos (Salmón, 2004a). Esta diferenciación es importante, dado que explica un hecho jurídico distintivo entre el CANI y el CAI en lo que respecta al derecho de hacer la guerra o el ius ad bellum, en palabras de la profesora Elizabeth Salmón:

"...el ius ad bellum prohíbe el uso de la fuerza entre estados pero no el uso de la fuerza al interior de un Estado. De esta manera, el CANI no resulta ser ilegal respecto al Derecho Internacional Público, pero sí lo será respecto del Derecho interno del Estado donde se verifique esta situación. Será por tanto el ordenamiento interno del Estado el que condene duramente la rebelión toda vez 
que no puede permitir una acción autodestructiva siendo, por el contrario, su prohibición garantía del mantenimiento de la paz y del orden. En cualquier caso, lo que sí se encuentra prohibido por el DIH de manera general, sea en el marco de un conflicto internacional o interno, es la comisión de violaciones a sus disposiciones fundamentales, supuesto en el que se aplica la faceta sancionadora del mismo." (Salmón, 2004b, p.114).

Si bien las definiciones del artículo 3 común y del protocolo II adicional no resultan ser idénticas, sí establecen mínimos básicos con base en los dos criterios antes mencionados, el de su intensidad, hace referencia al uso de la violencia y el de la organización de los bandos en pugna, presentándose solamente un matiz en lo referente a la prolongación de las acciones armadas, no obstante, es retomado por el Estatuto de Roma:

"Mención aparte merece el tema de la prolongación en el tiempo. Sobre esto no parece haber consenso en la medida en que los estados, al momento de elaborar el Protocolo Adicional II, descartaron introducir expresamente este requisito temporal por el riesgo de incorporar un elemento subjetivo. No obstante, esta característica es retomada en el Estatuto de Roma que crea la Corte Penal Internacional (CPI) para el supuesto específico de los crímenes cometidos en conflictos armados no internacionales" (Salmón, 2004c, p.30).

En resumen, la definición del Conflicto Armado permite un estándar mínimo que no pone en riesgo su reconocimiento y efectividad del $\mathrm{DIH}$, y a su vez garantiza los derechos y el reconocimiento de los sujetos protegidos por el DIH. En cualquier caso, los criterios esbozados por el corpus juris del DIH para definir el CANI se adaptan a la realidad del 
conflicto colombiano y así lo ha reconocido la jurisprudencia nacional ("Corte Constitucional - Sentencia C-291 de 2007, M.P. Manuel José Cepeda,"). El artículo 3 común establece la aplicación del DIH en los CANI, es decir, establece su ámbito de aplicación ratione materiae. A nivel interno, la Corte Constitucional definió que:

“...sobre la base del artículo 214.2 de la CP, el DIH (incluyendo el Protocolo II), 70 se aplica en todo tiempo y lugar, sin necesidad de analizar si el enfrentamiento cumple o no con los requisitos establecidos en el párrafo 1 del artículo 1 del Protocolo II. Igualmente, la Corte señaló que las exigencias de tratamiento humanitario que se derivan del DIH se aplican frente a situaciones de violencia que no adquieran una connotación bélica o las características de un conflicto armado, a pesar de la restricción establecida en el párrafo 2 del artículo 1 de dicho Protocolo."(Oficina en Colombia del Alto Comisionado de las Naciones Unidas para los Derechos Humanos, 2010, p. 150).

En cuanto al ámbito de aplicación ratione personae, el Derecho Internacional Humanitario, DIH, impone obligaciones a cada una de las partes en conflicto, y no únicamente al Estado, como sí sucede en el Derecho Internacional de los Derechos Humanos, DIDH, a su vez, extiende la protección a quienes han depuesto las armas, a quienes han quedado fuera de combate y a todas aquellas personas afectadas por el conflicto armado. Lo que respecta al ámbito de aplicación ratione temporis, la aplicación del DIH se da en tanto se extiendan los conflictos e incluso de manera posterior se mantendrán las disposiciones concernientes a la protección de las víctimas, por ejemplo, en caso de que persistan detenciones que se dieron con ocasión del conflicto, los detenidos se beneficiaran de las normas de protección emanadas del Protocolo Adicional 
II. No obstante, es necesario precisar, que en los conflictos no se predica un derecho especial a los prisioneros de fuerzas insurgentes en tanto:

"no existe un solo artículo en las normas que regulan el CANI donde se utilice la expresión "combatiente» para referirse a aquellos que participen en las hostilidades, y ello es así porque de esta forma se trata de evitar cualquier reconocimiento de un derecho a combatir que sí asiste a aquellos que participan en un CAl”'(Salmón, 2004d, p. 129).

Lo anterior implica que una vez terminado el conflicto, el Estado tiene plena potestad de juzgar a los alzados en armas con apego a su legislación, pues el DIH no predica el derecho a combatir de éstos ni modifica en absoluto el estatus jurídico que el Estado les asigna, lo cual supone un margen de discrecionalidad amplio en el tratamiento de las fuerzas insurgentes una vez terminan los conflictos, pues esta omisión del DIH del carácter de combatientes, no constituye per se una negación -o afirmación- de eventuales beneficios en el marco de procesos de justicia transicional para quien se alza en armas contra el Estado.

En conclusión, de la existencia del conflicto armado en Colombia se deriva un cuerpo normativo que impone obligaciones y de protección irrenunciables para los combatientes debido a que tales obligaciones derivan de un consenso universal, orientado por el respeto a la dignidad humana como valor supremo. (Gasser, 1998). Por tal razón en relación con la Ley de Justicia y Paz y en el marco de la Justicia Transicional, la observancia de las obligaciones internacionales del Estado Colombiano, son de esencial 
trascendencia, porqué Colombia se encuentra bajo el examen preliminar de la CPI desde junio de 2004. En este marco, la Fiscalía de la CPI publicó en el mes de noviembre de 2012 un reporte intermedio, en el que analiza algunos aspectos relativos a la competencia y admisibilidad de 94 comunicaciones que se encuentran bajo su conocimiento. En su informe, la Fiscalía de la CPI reconoció de manera explícita la comisión de crímenes de lesa humanidad por parte de las estructuras paramilitares que hoy se encuentran vinculadas al procedimiento de la ley 975 de 2005 entendiendo que, en prácticamente 15 casos con sentencia bajo esta legislación, existiría competencia temporal de la CPI.

\subsection{La Ley 975 a la luz de las diferencias entre el DIH y el DIDH}

El DIH y el DIDH son instrumentos del Derecho Internacional Público cuyo propósito es la salvaguarda de la dignidad humana, no obstante, subsisten varias diferencias que determinan su ámbito de aplicación, alcance de sus obligaciones, sujetos obligados y derivaciones históricas.

- El DIDH debe su nacimiento a procesos de reconocimiento de derechos ciudadanos cuyo desarrollo se da principalmente al interior de los países occidentales y su proceso de universalización es desde estos Estados hacia el resto del mundo, por su parte, el DIH se desarrolla entre la segunda mitad del siglo XIX y las dos guerras mundiales como mecanismo para poner freno a los sufrimientos de la guerra, y ante la imposibilidad de prohibirla, éste establece límites a la acción de los actores en conflicto 
y obligaciones frente a quienes no hacen parte de las hostilidades, de manera que su proceso nace en el marco del concierto internacional.

- $\quad$ El DIDH rige en todo momento y la suspensión de los DDHH o su limitación es extraordinaria, en contraste, la aplicación del DIH es extraordinaria, pues solo aplica en el marco de los conflictos y su extensión se deriva de la existencia de personas en situación de vulnerabilidad por ocasión del conflicto armado y no admiten su suspensión una vez se dan los hechos objetivos que demanden su aplicación, a saber, la existencia de CAI o CANI.

- En el DIDH la responsabilidad por las violaciones a los Derechos Humanos es del Estado, pues es éste el obligado a garantizar su goce efectivo, mientras en el DIH la responsabilidad de las violaciones recae sobre responsables individuales, actores del conflicto, que incurran en los delitos establecidos en el estatuto de Roma: genocidio, crímenes de lesa humanidad, crímenes de guerra y agresión.

- En cuanto al sujeto protegido, el DIDH protege a todas las personas humanas sin discriminación, mientras que el DIH establece tipos específicos de sujetos a proteger: aquellos que resulten en estado de vulnerabilidad con ocasión del conflicto armado.

- Por todo lo anterior, los mecanismos de activación y protección de unos y otros son distintos, y en materia internacional, es claro que la activación de mecanismos de protección de DIDH tienen como propósito fundamental el establecimiento de medidas restaurativas frente a la víctima, mientras el $\mathrm{DIH}$, si bien no deshecha los derechos de las víctimas, sí tiene un carácter eminentemente punitivo frente a los victimarios. 
Las diferencias entre el DIH y el DIDH, hacen de estos, dos subsistemas del DIP de carácter complementario, cuyo propósito es la defensa de la dignidad humana y cuya aplicación, lejos de reñir, sirve de refuerzo frente a la protección de ésta. Colombia ha suscrito los instrumentos de protección del DIDH y del DIH. Respecto al primero, ha suscrito buena parte de los instrumentos del sistema universal de Naciones Unidas y del SIDH, Sistema Interamericano de Derechos Humanos, con respecto al segundo, el instrumento más importante para la garantía de justicia por violaciones contra el DIH, es el Estatuto de Roma, incorporado a las Constitución Política mediante el Acto Legislativo 02 de 2001, ratificado en noviembre de 2002. La ratificación de estos instrumentos impone restricciones a la acción estatal frente a procesos de paz en materia de los beneficios que se pueden otorgar a ex combatientes en el marco de un proceso de justicia transicional, pues tanto el DIH, como el DIDH imponen estándares mínimos en materia de justicia que deben ser acogidos si no se quiere abrir la puerta a la posterior activación de instrumentos internacionales por parte de las víctimas de los actores armados.

Al desarrollar la naturaleza e imperatividad del derecho internacional humanitario y la jerarquía normativa de los convenios que en esta materia han sido aprobados y ratificados por Colombia, la Corte Constitucional también ha distinguido entre el DIH y el DIDH, así: 
"Para ello conviene tener en cuenta que estos convenios hacen parte, en sentido genérico, del corpus normativo de los derechos humanos, puesto que, tanto los tratados de derechos humanos en sentido estricto como los convenios de derecho humanitario son normas de ius cogens que buscan, ante todo, proteger la dignidad de la persona humana. Son pues normatividades complementarias que, bajo la idea común de la protección de principios de humanidad, hacen parte de un mismo género: el régimen internacional de protección de los derechos de la persona humana. La diferencia es entonces de aplicabilidad, puesto que los unos están diseñados, en lo esencial, para situaciones de paz, mientras que los otros operan en situaciones de conflicto armado, pero ambos cuerpos normativos están concebidos para proteger los derechos humanos. Así, esta Corporación ya había señalado que "el derecho internacional humanitario constituye la aplicación esencial, mínima e inderogable de los principios consagrados en los textos jurídicos sobre derechos humanos en las situaciones extremas de los conflictos armados. " (Sentencia C 255 de 1995 M.P. Alejandro Martínez Caballero).

Ahora bien, en materia de DIDH las obligaciones del Estado son:

- Respeto: el artículo 1 de la Convención Americana de Protección de Derechos Humanos obliga al Estado a no violar los derechos de los ciudadanos y a evitar que terceros los violen. 
- Garantía: implica el desarrollo de medidas legislativas, administrativas, judiciales y de cualquier tipo que permitan al Estado avanzar en el goce efectivo de los DDHH y suponen cuatro tipos de acciones estatales:

- $\quad$ Prevención: es una obligación de medio y no se demuestra su cumplimiento por la violación de un derecho

- Investigar: es una obligación de medio y debe hacerse ex oficio.

- Sancionar: la obligación de sancionar es ineludible, y como se verá a continuación, limita la discrecionalidad estatal en materia punitiva.

- Reparar: el propósito de la reparación es desaparecer los efectos de la violación de $\mathrm{DDHH}$, compensar los daños y de ser posible, restituir a la víctima a la situación previa a la violación de sus derechos. Esta tiene varios componentes:

- Restitución: retorno de la víctima a la situación previa a la violación de sus derechos.

- Rehabilitación: hace referencia a la atención necesaria para superar el daño causado.

- Satisfacción: implica el reconocimiento público del daño, su difusión y actos de contrición.

- Indemnización: no supone un castigo ejemplarizante para el Estado, sino una medida de compensación para las víctimas.

- $\quad$ No repetición: acciones que eviten la re victimización.

En el marco del proceso de paz con los grupos paramilitares, la obligación estatal que más se vio comprometida es la de sancionar, pues este proceso en el marco de justicia 
transicional supuso una rebaja de la acción punitiva a cambio de medidas de verdad y reparación para las víctimas, no obstante, los estándares del Sistema Interamericano de Derechos Humanos y del DIH implican que la sanción punitiva es un hecho ineludible, en concreto la Ley 975 supuso una relación poco equilibrada entre las sanciones y la gravedad de los delitos cometidos por los miembros de los grupos desmovilizados, en especial los más graves en el marco de la legislación internacional. De otra parte, también es preciso mencionar que tanto en el marco del DIH, como del DIDH, se entiende que medidas punitivas no necesariamente implican encarcelamiento, pero sí penas punitivas para los máximos culpables, no obstante, en la Ley 975 la máxima pena admitida era de ocho años (Comisión Colombiana de Juristas , 2007).

Merece especial atención para el país, la sentencia emitida por la Corte Interamericana de Derechos Humanos en el caso de "el Mozote y lugares aledaños Vs El Salvador". Allí la Corte desestimó la amnistía dada por el Salvador a los combatientes de ambos bandos tras el proceso de paz y dejó claro que ésta va en contra de las obligaciones de El Salvador en el marco del (SIDH), en tanto este tipo de acciones niegan la obligación de investigar, construir la verdad judicial, individualizar los responsables de las violaciones de Derechos Humanos e imponer las sanciones correspondientes. En lo que respecta al $\mathrm{DIH}$, las violaciones sistemáticas de los actores armados a los principios de este cuerpo normativo han sido protuberantes y constituyen la norma de su accionar. Vale la pena definir cuatro de los principios más importantes del DIH para evidenciar su violación, la 
cual constituye crímenes de Lesa Humanidad y en otros casos, ${ }^{3}$ Crímenes de Guerra ${ }^{4}$ (Corte Interamericana de Derechos Humanos Caso Masacre de el Mozote y lugares aledaños, 2012).

- Pro Homine: denominado por alguna literatura como la regla de buena fe implica que las normas del DIH y del DIDH siempre deben regirse bajo una regla garantista que señala que: I) frente a una norma y varias interpretaciones, debe siempre acogerse aquella que sea más garantista; II) frente a un conflicto entre varias normas de DIH o DIDH, debe acogerse siempre aquella que sea más garantista; III) Las nuevas normas deben ser tanto o más garantistas que las anteriores, de lo contrario no aplica la derogación de las normas anteriores por las ulteriores.

- Principio de distinción: supone una regla inquebrantable para los actores armados e implica que estos deben abstenerse de ejecutar cualquier acto que ocasione daño a civiles o bienes civiles.

${ }^{3}$ Definido por el Estatuto de Roma "A los efectos del presente Estatuto, se entenderá por "crimen de lesa humanidad" cualquiera de los actos siguientes cuando se cometa como parte de un ataque generalizado o sistemático contra una población civil y con conocimiento de dicho ataque". Articulo 7

4 violaciones graves a las leyes, usos y costumbres de la guerra, una de las diferencias de los crímenes de lesa humanidad con los crímenes de guerra tiene que ver con el carácter generalizado y sistemático de los primeros. 
- Principio de proporcionalidad: están prohibidos los métodos y armas que ocasionen daños innecesarios o excesivos a otros combatientes o a los civiles respecto a la ventaja militar pretendida.

- Principio de no discriminación: se prohíbe cualquier trato desfavorable en razón de condiciones de sexo, raza, posiciones políticas u otro, no obstante, se permiten tratos diferenciados siempre que tengan como propósito brindar mayores grados de garantía de derechos a quienes lo requieran.

Las violaciones al DIH cometidas por los actores armados, específicamente por los grupos paramilitares en desarrollo del conflicto armado colombiano, suponen la comisión constante de daños a los civiles y sus bienes, actos bélicos que no guardan proporción con la ventaja militar esperada, crímenes contra la infraestructura civil y del Estado, en general, tantos y tan innumerables actos atroces, que suponen la mayoría de las veces crímenes de guerra y en otras, como en el caso de los desplazamientos, violencia de género y el reclutamiento de menores, constituyen crímenes de lesa humanidad (Ambos, 2010a).

El DIH prevé procesos de justicia transicional que implican rebajas en materia de estándares de justicia, siempre que se cumplan mínimos y que, a su vez, exista una compensación en materia de verdad y reparación. No obstante, la principal dificultad que afronta el proceso de paz tiene que ver con la posición sostenida hasta hoy por los grupos paramilitares, en el sentido de asistir a las audiencias de reconocimiento de sus acciones 
punibles sin que exista ninguna obligación efectiva de revelar toda la verdad sobre los hechos victimizantes, o la obligación perentoria de reparar a sus víctimas con sus bienes (Comisión Colombiana de Juristas , 2007). En tal sentido los críticos del proceso alegan que, en el proceso de Justicia y Paz, la acción penal del Estado materializada en esta ley está centrada en la resocialización del victimario y no de resarcir los derechos de las víctimas.

La Corte Penal Internacional a través de sus fiscales, ha advertido al país en repetidas oportunidades que de no existir investigación y sanción para los máximos responsables de crímenes de guerra y de lesa humanidad en el marco de Ley de Justicia y Paz está directamente ligada al agotamiento de las vías judiciales creadas por el propio Estado, y sólo si ellas no cumplen con el objetivo primordial de garantizar justicia a las víctimas de estos crímenes, se generaría la competencia para que la Corte pueda conocer la situación. Este requisito de acceso a la jurisdicción penal internacional opera bajo la figura jurídica de principio de complementariedad, conforme al cual, "la Corte Penal Internacional constituye una jurisdicción de ultima ratio que solo puede activarse y ejercitarse ante la inacción, la falta de disposición o la incapacidad de las jurisdicciones nacionales" (Olásolo, 2015c). 


\subsection{Elementos de Justicia Transicional para desarrollar un acuerdo de paz y desmovilización}

Aproximadamente medio siglo durante el cual el país ha estado inmerso en un conflicto armado que ha generado, como hemos visto, graves afectaciones a los ciudadanos víctimas de las más atroces manifestaciones de violencia que se han perpetuado en desarrollo de este fenómeno, en especial aquellas que habitan territorios rurales (Guzmán. D.E, 2010). Esta situación generó una inseguridad jurídica respecto de la protección de Derechos Fundamentales y demás garantías establecidas en normas Nacionales e Internacionales. El ordenamiento jurídico ha sido transgredido por los diversos grupos armados al margen de la ley, a lo largo de las casi cinco décadas de confrontación armada. Como consecuencia de esta vulneración de derechos, desprotección del Estado e ineficacia de éste para garantizar la seguridad a los ciudadanos que habitan el territorio Nacional, se ha evidenciado el desarrollo de una profunda crisis humanitaria que a la fecha ha dejado como consecuencia un número de más de cinco millones de colombianos víctimas del desplazamiento forzado, entre otros

muchos y graves hechos delictivos, de acuerdo a las cifras anuales reportadas por la Consultoría para los Derechos Humanos y el Desplazamiento -CODHES- (Consultoría para los derechos Humanos y el Desplazamiento, 2018. Recuperado de http://www.codhes.org/index.php?option=com si\&type=1).

Colombia como Estado Social de Derecho establecen la armonía entre las diferentes normas nacionales e internacionales en materia de Derechos Humanos por medio de la acción del Bloque de Constitucionalidad. Dentro de los fines del Estado se identifica la 
garantía de la seguridad nacional, este derecho debe permear en cada uno de los ciudadanos el Estado y sus Instituciones deben orientar sus acciones en pro del reconocimiento de la dignidad humana, prevenir toda clase de conflictos que lleguen a perturbar la paz y la convivencia pacífica en la sociedad (Martínez, Claudia \& Pérez, Andrea, 2012. La restitución de tierras en Colombia, expectativas y retos. Prolegómenos. Derechos y valores, volumen 29, p. 112-127. Recuperado de http:// http://www.redalyc.org/articulo.oa?id=87625419008). En la Constitución de 1991 el Estado Colombiano adquirió deberes y obligaciones para la adecuada garantía de derechos inherentes al hombre, no obstante, la realidad ha mostrado que el cumplimiento de los derechos de la Carta es aún incipiente, mucho más, con el desarrollo de un conflicto armado en el cual se han vulnerado derechos y premisas elementales de salvaguarda de la dignidad humana, además de las más graves violaciones del Derecho Internacional de los Derechos Humanos y del Derecho Internacional Humanitario.

De tal suerte, que es necesario tener en cuenta que la normatividad Internacional al evidenciar la ocurrencia de estos hechos se orienta a establecer normas y recomendaciones para que se mitiguen los impactos generados por los mismos y para que los Estados garanticen los derechos de los ciudadanos (Comisión Colombiana de Juristas , 2011). La obligación del Estado en materia de reparación integral a los desplazados víctimas del conflicto, encuentra también su justificación en el Derecho Internacional de los Derechos Humanos que protege a la población civil que puede verse afectada por un conflicto interno, específicamente en los principios rectores sobre 
desplazamiento forzado y en la Jurisprudencia sobre la materia emanada de la Corte Interamericana de Derechos Humanos (Comisión Colombiana de Juristas , 2011).

La catalogación del daño surge como concepto central en la reparación con arreglo al Estado como sujeto titular de responsabilidad contractual y extracontractual, concepto que permite la adopción de estándares ciertos frente a los topes de justicia, verdad y reparación, tanto en el plano material como el simbólico, aspecto último en el que la ley hace un énfasis especial. La justicia transicional deber ser indudablemente una lucha contra la impunidad, disputa que está a favor de la justicia para aquellas personas que han sido víctimas del conflicto armado interno en circunstancias específicas, o en un tiempo determinado por el legislador y a consideración de este, percepción que debe tener como finalidad la reparación, la justicia y la verdad para las víctimas del conflicto armado interno, así mismo la garantía de sostener los principios y eficacia que sujeta cada uno de los derechos humanos (Comisión Colombiana de Juristas , 2007).

Una seria falencia que en la práctica asumió la Ley de Justicia y Paz en el Gobierno Uribe Vélez, fue la ineficacia para proveer la realización efectiva de la reparación integral, la justicia y sobre todo la verdad, garantías que esta ley someramente señaló proteger, preocupándose demás por la desmovilización o desvinculación de los perpetradores, dejando detrás y sin historia las personas que fueron víctimas de estos grupos y las cuales tiene derecho a una justa reparación. En este orden de ideas, es preciso afirmar que la mayor inexactitud por parte del legislador al expedir la ley de Justicia y Paz, fue la ausencia de un mecanismo eficaz para la prevención y ayuda de aquellas personas que 
estaban siendo lesionadas de modo patrimonial y extra patrimonial, permitiendo así un masivo quebrantamiento de los derechos humanos, toda vez que se omitió una preocupación tan simple como lo es la búsqueda de aquellos responsables que produjeron el daño y que continuamente lesionaron un bien jurídico tutelado por el ordenamiento legal, ahora bien, la solución jurídica para este conflicto reposa en las consideraciones expuestas por la Ley 1424 de 2010 y el Decreto 2244 de 2011, ordenanzas que traen consigo mecanismos satisfactorios para la contribución a la verdad y a una reparación patrimonial y extra patrimonial.

Se colige que las leyes citadas hasta el momento han obrado como justicia transicional, situación que es ineficaz, pues no salvaguardan una seguridad jurídica y no implementan los mecanismos adecuados para una verdad y pronta justicia, es así, que el legislador debe aplicar un ámbito en el cual no deba replantear el acceso de dichos derechos a través de un solo procedimiento, sino por el contrario, debe ser de carácter racional, equitativo, axiológico y hermenéutico.

\subsection{Sentencias que desarrollan el estándar de reparación}

\begin{tabular}{|l|l|}
\hline $\begin{array}{l}\text { Sentencia C-253/2012 } \\
\text { M.P. Humberto Antonio Sierra Porto }\end{array}$ \\
\hline Normas Demandadas & $\begin{array}{l}\text { Artículo } 75 \text { y artículo 3 de la ley } 1448 \text { de } \\
2011 .\end{array}$ \\
\hline Problema Jurídico & $\begin{array}{l}\text { Determinar si los límites temporales que } \\
\text { señala la norma acusada para ser } \\
\text { considerado como víctima destinataria al } \\
\text { reconocimiento de medidas de atención, } \\
\text { asistencia y reparación integral a efecto }\end{array}$ \\
\hline
\end{tabular}




\begin{tabular}{|l|l|}
\hline & de obtener la restitución jurídica y \\
material de las tierras abandonadas \\
como consecuencia del conflicto \\
armado, transgrede el artículo 13 de la \\
Constitución Política de Colombia.
\end{tabular}

a fundamentos

Los artículos citados de la ley de víctimas señalan un límite temporal para que las personas que tengan la calidad de víctimas puedan acceder al beneficio de dicha ley, garantía que recae en la restitución jurídica y material de tierras que han sido despojadas o abandonadas como consecuencia del conflicto armado.

Ahora bien, la Corte Constitucional se permite realizar un análisis al comprender que el conflicto armado viene zozobrando a mediados de los año 40, ejerciendo violencia y despojando forzadamente a las personas que habitan sus tierras, por lo cual, hasta la presente no se puede determinar la fechas exactas en que las víctimas fueron lesionadas, por otro lado, se aducen cuestionamientos que pueden llegar a determinar la fecha puntual que dio origen e incurso la violencia y por ende el despojo de tierras, acarreando un tratamiento discriminatorio e injustificado por parte de los grupos al margen de la ley.

Adicionalmente, la Corte Constitucional determinó que el legislador al señalar la temporalidad de la ley objeto de estudio fue veraz y eficiente en su periodo estacional, señalando que la rama legislativa realizó una serie de estudios con la intervención de personas jurídicas y naturales que son competentes y acordes a la situación, arrojando como resultado el aumento sustancial y relevante de víctimas como consecuencia del conflicto armado a partir de los años 80 .

Es necesario mencionar los siguientes aspectos que fueron objeto de disertación para discernir el periodo en el cual se reconoce la calidad de víctima y poder acceder a la restitución de tierras, análisis instruido por el legislador y el cual surgió con base a: "1. El estudio realizado reportó que el conflicto armado se incrementó a partir de los años 80. 2. El estudio arrojó que a partir del año 1990 se incrementaron en un $100 \%$ la expulsión y despojo de tierras por parte de grupos al margen de la ley contra la población civil. 3. No hay reseñas históricas, registros, ni constancias que demuestren que antes de los años noventa la población civil fue forzada mediante violencia a dejar sus tierras. 4. Las estadísticas del INCODER, reflejan que la mayoría de despojos de tierras está comprendido entre el año 1997 y 2008".

Decisión

La Corte Constitucional expresa que los articulo 3 y 75 de la ley 1448 de 2011, resultan exequibles.

\section{Sentencia C-052/2012}

M.P. Nelson Pinilla Pinilla

Normas Demandadas

Expresiones "en primer grado de consanguinidad, primero civil" y "cuando 


\begin{tabular}{|c|c|}
\hline & $\begin{array}{l}\text { a esta se le hubiere dado muerte o } \\
\text { estuviere desaparecida, ambas } \\
\text { contenidas en el inciso } 2 \text { del artículo } 3 \text { de } \\
\text { la Ley } 1448 \text { de } 2011 \text {. }\end{array}$ \\
\hline Problema Jurídico & $\begin{array}{l}\text { Establecer si el artículo } 3 \text {, inciso } 2 \text { de la } \\
\text { Ley } 1448 \text { de 2011, contraviene el } \\
\text { artículo } 13 \text { de la Carta Política suscrita } \\
\text { en } 1991 \text {, al señalar que se reconoce } \\
\text { como víctima al cónyuge, compañero } \\
\text { permanente o familiares que se } \\
\text { encuentren en primer grado de } \\
\text { consanguinidad o civil, atendiendo el } \\
\text { requisito que la víctima haya fallecido o } \\
\text { este desaparecida como consecuencia } \\
\text { del conflicto armado interno, excluyendo } \\
\text { de este derecho a los demás familiares, } \\
\text { por lo cual se les vulnera el derecho a la } \\
\text { igualdad y a la reparación. }\end{array}$ \\
\hline \multicolumn{2}{|l|}{ Fundamentos } \\
\hline \multicolumn{2}{|c|}{$\begin{array}{l}\text { La Corte Constitucional ha realizado un exhaustivo estudio sobre la noción que trae } \\
\text { implícita la norma demanda, trayendo en primer lugar la conceptualización de } \\
\text { víctima y por ende su reconocimiento, ante lo cual, se desarrolla un concepto claro } \\
\text { y preciso respecto a la percepción de daño, atendiendo una serie de eventualidades } \\
\text { en la que un sujeto de derechos resulta lesionado, de manera tal, que el daño es } \\
\text { generado de forma directa o indirecta a través de sus familiares que de una manera } \\
\text { u otra sintieron miedo, terror, angustia y nostalgia, a través de la violencia física o } \\
\text { emocional, ultimando que víctima es aquella persona que ha sufrido daño y/o lesión } \\
\text { patrimonial o extra patrimonial como consecuencia del conflicto armado interno en } \\
\text { Colombia. }\end{array}$} \\
\hline \multicolumn{2}{|c|}{$\begin{array}{l}\text { Ahora bien, una vez realizada la distinción normativa señalando que familiares son } \\
\text { reconocidas como víctimas y en que eventos tienen derecho a la reparación, se } \\
\text { denota como requisito principal la inclusión del concepto de daño mediante } \\
\text { cualquier aspecto, ante lo cual la Corte Constitucional ha señalado que esta figura } \\
\text { no proviene solo de la Constitución Política, sino por el contrario de una serie de } \\
\text { normatividades y tratados internacionales ratificados por el estado de Colombia. }\end{array}$} \\
\hline \multicolumn{2}{|c|}{$\begin{array}{l}\text { De igual manera, resulta necesario precisar la necesidad que tiene el legislador de } \\
\text { delimitar su campo normativo, a efecto de que su aplicación sea eficaz y veraz en } \\
\text { pro de la población civil, razón por la cual es inevitable delimitar su campo de } \\
\text { acción, competencia que la misma Constitución Política de Colombia le ha otorgado } \\
\text { a la rama legislativa, siendo así, que la Corte Constitucional evidencia que el } \\
\text { artículo } 3 \text { de la norma ocupada tiene un concepto basto y suficiente al señalar quien } \\
\text { es víctima para efectos de la restitución de tierras, precisando que estas reglas } \\
\text { tienen un elemento aditivo y no por el contrario limitativo. }\end{array}$} \\
\hline
\end{tabular}




\section{Decisión}

Declarar exequible la norma acusada, en el entendido que también son víctimas las personas que sufran de alguna manera $u$ otra un daño directo o indirecto.

\begin{tabular}{|l|l|}
\hline $\begin{array}{l}\text { Sentencia T-025/2004 } \\
\text { Magistrados Ponentes. Manuel José Cepeda, Jaime Córdoba Triviño, Rodrigo } \\
\text { Escobar Gil }\end{array}$ \\
\hline Normas Demandadas & $\begin{array}{l}\text { Todos y cada uno de los principios y } \\
\text { derechos constitucionales inherentes a } \\
\text { la persona. }\end{array}$ \\
\hline
\end{tabular}

Problema Jurídico

La acumulación de Acciones de Tutelas interpuestas por los ciudadanos en aras de obtener una pronta y efectiva ayuda en pro de la población desplazada, ante lo cual, la Corte Constitucional ha revisado cada una de las pretensiones instauradas a través de este mecanismo, planteado una diversidad de problemas jurídicos en relación al alcance de políticas estatales para la protección de derecho constitucionales e inherentes a las personas.

La Corte Constitucional ha evidenciado los siguientes factores dentro del conflicto socio jurídico: "1. La grave situación de vulnerabilidad que aqueja a la población desplazada. 2. Los problemas que enfrentan a raíz de la forma como están siendo atendidas sus solicitudes por las entidades demandadas. 3. El tiempo excesivamente prolongado que ha transcurrido sin que hayan obtenido las ayudas previstas. 4. El altísimo volumen de tutelas que presentan los desplazados para obtener ayuda y al hecho de que varias entidades hayan convertido la acción de tutela como parte del procedimiento ordinario para obtener la ayuda solicitada. 5. Que la situación que se pretende resolver mediante la presente tutela afecta a toda la población desplazada. 6. Que la mayor parte de los problemas planteados se ha presentado de manera reiterada desde que se estableció la política para la atención de la población desplazada".

Se considera como problema jurídico la vulneración del mínimo vital y el otorgamiento de respuestas a las peticiones ejercidas por los desplazados, quebrantamiento basado principalmente en la abstinencia económica, reubicación, educación, derecho a la vida, dignidad humana, atención integral y a la salud, mecanismos que cuenta con una serie de recursos que son inútiles o insuficientes.

\section{Fundamentos}

En razón a la acumulación de acciones de tutelas interpuestas por la población desplazada, la Corte Constitucional ha resaltado que efectivamente el Estado de Colombia presenta fallas en su sistema, pues las victimas que sufren el desplazamiento forzado no cuentan con las ayudas necesarias que deben ser proporcionadas de manera obligatoria. 
Por otro lado, la Corte deduce que este hecho circunstancial está afectando de manera colectiva a la población generando pánico en la comunidad, así mismo, denota que en la mayoría de casos se vulneran derechos como: la la salud, la vida, dignidad humana, vivienda, educación, entre otros, de igual manera señala que las personas víctimas del desplazamiento forzado no cuentan con garantías constitucionales suficientes para su protección y no repetición.

La Corte Constitucional obra como garante de los principios consagradas en nuestra carta política con la finalidad de proteger los derechos fundamentales e inherentes a una población vulnerable, de manera tal que ha delgado esta competencia a instituciones jurídicas privadas y oficiales, estipulaciones que en el desarrollo de sus funciones no han sido del todo efectivo y proporcional para el beneficio de las personas que se encuentran en estado de vulnerabilidad, por lo cual, la Corte Constitucional ha declarado un Estado de Cosas Inconstitucionales.

En el presente caso se denomina un Estado de Cosas Inconstitucionales, toda vez que se determinó de forma clara y precisa los siguientes aspectos: 1. La vulneración colectiva de derecho fundamentales. 2. La omisión de las autoridades en pro de sus deberes para garantizar ciertos derechos. 3. La utilización de la acción de tutela para acceder a la protección de un derecho que es cierto e indiscutible. 4. La omisión por parte de las autoridades competente para expedir medidas legislativas que protejan los derechos fundamentales. 5 . La existencia de un problema socio jurídico, cuya solución compromete la intervención de varias instituciones jurídicas. 6. La existencia de una cogestión judicial, puesto que varias personas accedieron a la acción de tutela a efecto de que se les protegiera el mismo derecho.

Ahora bien, la Corte Constitucional señala que la parte resolutoria del presente fallo solo tendrá efectos para las personas que tengan la calidad de víctima, por la cual enfatiza reiterativamente este concepto basado en que el "desplazado es aquel que se ve forzado a abandonar la zona en la que habita a causa de la violencia". Es así, que la Corte Constitucional reafirma la necesidad de proteger los derechos fundamentales de cada accionante de manera preferencial, inmediata, eficaz y efectiva, dando aviso de este hecho a las instituciones jurídicas pertinentes, a efecto de que estas utilicen todos los medios para garantizar dichos derechos.

Ante la continua y sistematizada vulneración de derechos, la omisión de los organismos del Estado para protegerlos y la utilización del mecanismo de Acción de Tutela como único recurso, se advierte a las instituciones jurídicas pertinentes que deben generar y ejecutar planes que permitan dar respuesta en aras de garantizar los derechos fundamentales trasgredidos de las personas que han sido víctimas del desplazamiento interno.

\section{Decisión}

Se declara el Estado de Cosas Inconstitucionales, así mismo se ordena un plazo razonable para que las entidades competentes públicas y oficiales, adopten un programa 
encaminado a corregir las falencias institucionales.

\section{Sentencia C-781/2012 \\ M.P. María Victoria Calle Correa Normas Demandadas}

\section{Problema Jurídico}

Artículo 3 Ley 1448 de 2011, por la cual se define Victima.

Determinar el artículo 3 de la Ley 1448 de 2011, vulnera el derecho a la igualdad, verdad, justicia y reparación integral de las víctimas, toda vez que este artículo solo hace énfasis a las víctimas del conflicto armado interno, excluyendo aquellas personas que obtenga algún tipo de daño como consecuencia de hechos de violencia sociopolítica dentro de un conflicto armado pero sin relación a este, es decir, determinar si es constitucional o no la expresión "Con ocasión del conflicto armado".

\section{amentos}

Para dar un concepto decisivo respecto del presente conflicto jurídico, la Corte Constitucional ha señalado la indebida interpretación del texto normativo acusado, resaltando explícitamente que en el concepto de víctima, si bien es cierto, esta definición abarca una determinada población excluyendo a otra, no es menos cierto afirmar, que esta conceptualización reposa en la ley, en la jurisprudencia, tratados internacionales y demás al respecto, concluyendo que las víctimas no solo son las que resultan del conflicto armado interno; sino por el contrario todas las personas a las que se les vulneran sus derechos y ven afectados sus intereses personales; en este sentido, el derecho a reclamar una reparación no se encuentra limitada en el artículo 3 de la Ley 1448 de 2011, y así mismo no se encuentra delimitado para un individuo específico.

En esencia la calidad de víctima reposa en las personas que de una manera u otra sufran algún tipo de daño, situación que tiene como efectos establecer la verdad, sancionar a los victimarios y reparar integralmente a la víctima, por lo cual, es necesario realizar la distinción de víctima como ocasión del conflicto armado y de la delincuencia común, siendo así que las víctimas del conflicto armado se define de manera clara y taxativa en el artículo 3 de la Ley 1448 de 2011, y que para los demás caso se acude a los mecanismos que la jurisdicción ordinaria ha implementado para su debida atención.

Para efectos de aplicar la Ley 1448 de 2011, se establecen los siguientes criterios: "1). El temporal: los hechos de los que se deriva el daño deben haber ocurrido a partir del 1 de enero de 1985. 2). El relativo a la naturaleza de las conductas 
dañosas, que deben consistir en infracciones al Derecho Internacional Humanitaria (DIH) o violaciones graves manifiestas a las normas internacionales de Derechos Humanos (DIDH), y 3). Contexto: los hechos deben haber ocurrido con ocasión del conflicto armado interno". Se concluye que la expresión "con ocasión del conflicto armado" en conexidad con la conceptualización de víctima, delimita los beneficiarios a que haya lugar, como quiera que aquellos que lleguen a ser considerados como tales por hechos ilícitos ajenos al contexto del conflicto armado, aun cuando no sean favorecidos por la Ley 1448 de 2011, pueden acudir a la totalidad de las herramientas y procedimientos ordinarios en defensa y garantía de sus derechos provistos por el estado de Colombia y su sistema jurídico.

\begin{tabular}{l|l} 
Decisión & $\begin{array}{l}\text { Declarar EXEQUIBLE la expresión } \\
\text { "ocurridas con ocasión del conflicto } \\
\text { armado interno. }\end{array}$ \\
\hline
\end{tabular}

\section{Sentencia C- 715 de 2012 \\ Luis Ernesto Vargas Silva}

Normas Demandadas

Las expresiones de los artículos 28, 70, $72,73,74,75,76,77,78,84,91,99$ у 207 de la Ley 1448 de 2011, toda vez que vulneran los derechos a la verdad, justicia, reparación y la restitución.

\section{Problema Jurídico}

"(i). Si se configura omisión legislativa relativa por parte del Legislador en la regulación de: (a). los artículos 28 numeral 9, y artículo 72 de la Ley 1448 de 2011, respecto de la no inclusión de bienes abandonados; (b). los artículos 70, 72, 73 y 75 de la Ley 1448 de 2011, por la no inclusión de los bienes muebles; (c). los artículos 74 inciso 6 parcial, 75 parcial, 76 inciso 4 parcial, 77 numeral 3 y 4 parciales, 78 parcial, 84 parágrafo 2 parcial y 91 inciso primero parcial de la Ley 1448 de 2011, en razón a la no inclusión de los tenedores.

(ii). Si el artículo 76 inciso 5 de la Ley 1448 de 2011 que regula el registro de tierras despojadas y abandonadas forzosamente es violatorio del derecho al acceso a la justicia de las víctimas y de los derechos a la restitución como parte esencial de la reparación integral.

(iii). Si el artículo 77 numeral 3 parcial de la Ley 1448 de 2011, al consagrar una presunción de despojo en favor de los opositores y en contra de las víctimas respecto de los predios inscritos en el registro de tierras despojadas, es violatoria de los derechos de las víctimas a la restitución, al debido proceso y al acceso a la justicia.

(iv). Si el artículo 99 de la Ley 1448 de 2011 al consagrar la posibilidad de suscribir contratos de uso, vulnera el derecho a la restitución de tierras de las víctimas, el derecho a la propiedad, el derecho de acceso progresivo a la propiedad de la tierra de los trabajadores agrarios, el derecho al trabajo, el derecho a la libre escogencia de profesión u oficio y el derecho a la igualdad". 


\section{Fundamentos}

En relación con los derechos a la verdad, justicia y reparación, la jurisprudencia de la Corte Constitucional ha referido en varias oportunidades el Derecho Internacional Humanitario desarrollado en tratados ratificados por el Estado de Colombia, como lo son; la Convención Interamericana, el Pacto Internacional de Derechos Civiles y Políticos y el derecho comparado, por lo cual la Corte Constitucional ha contemplado que: "(i) las víctimas de graves violaciones de los derechos humanos, del derecho internacional humanitario o de crímenes de lesa humanidad tienen derecho a ser reparadas de manera adecuada, proporcional, integral y eficaz respecto del daño sufrido; (ii) la reparación se concreta a través de la restitución íntegra o plena, pero también a través de la indemnización, de la rehabilitación, de la satisfacción de alcance colectivo, y de la garantía de no repetición; (iii) la reparación a las víctimas por el daño ocasionado se refiere tanto a los daños materiales como a los inmateriales, (iv) la reparación se concreta a través de medidas tanto individuales como colectivas, y que (v) estas medidas se encuentran encaminadas a restablecer a la víctima en su dignidad por el grave daño ocasionado".

En relación con la indemnización, la Corte Interamericana ha establecido que la compensación debe estar orientada a procurar una pronta restitución de los daños causados por el hecho violatorio de los derechos humanos. En caso de no proceder con la restitución se debe generalizar un resarcimiento económico por la indemnización de daños morales y materiales que la persona ha sufrido directamente o la de sus familiares como consecuencia del conflicto armado interno.

En cuanto al derecho a la justicia, la Corte en su jurisprudencia ha establecido diversas reglas, tales como: "(i) la obligación del Estado de prevenir las graves violaciones de derechos humanos, especialmente cuando se trata de violaciones masivas, continuas y sistemáticas como el desplazamiento forzado interno, y (ii) la obligación del estado de luchar contra la impunidad".

En relación con el derecho a la verdad, la Corte ha establecido: "(i) éste se encuentra consagrado en los principios 1 a 4 de los Principios para la protección y promoción de los derechos humanos mediante la lucha contra la impunidad, y encuentra su fundamento en el principio de dignidad humana".

En cuanto al derecho a la reparación, se fijó: "(i) el reconocimiento expreso del derecho a la reparación como un derecho internacional y constitucional de las víctimas, como en el caso del desplazamiento forzado, y (ii) el derecho a la reparación integral y las medidas que este derecho incluyese encuentran regulados por el derecho internacional en todos sus aspectos"

En este sentido, el derecho a la reparación incluye tanto medidas destinadas a la satisfacción de la verdad y de la memoria histórica, como medidas destinadas a que se haga justicia en aras de investigar y sancionar los responsables. Por lo tanto, 
la Corte ha evidenciado el derecho a la reparación como un derecho complejo, en cuanto se encuentra en una relación de conexidad con los derechos a la verdad y a la justicia.

El daño acaecido por la violación flagrante de los derechos humanos, genera a favor de las víctimas el derecho a la reparación, restitución, indemnización, rehabilitación, satisfacción y la no repetición consagradas en el Derecho Internacional. La exigencia y la satisfacción de este derecho surgen independientemente de la identificación, aprehensión, enjuiciamiento o condena del victimario, debido a que es obligación del Estado salvaguardar la víctima sin perjuicio de que pueda repetir contra el autor.

En consideración con las decisiones de la Corte, se comprenden grandes retos para el Gobierno Nacional y sus Decisión Instituciones, la garantía de los derechos a la vedad, justicia, reparación y acciones de no repetición, van más allá de la sola implementación de meras acciones artificiales que no apunten a una reparación integral, como bien lo ha expresado la Corte Constitucional, sin embargo se declara exequible las expresiones contenidas en los artículos demandados.

\begin{tabular}{l} 
AUTO 219 DE 2011 \\
M.P. LUIS ERNESTO VARGAS SILVA, NELSON PINILLA PINILLA, JUAN \\
CARLOS HENAO PÉREZ \\
Antecedentes \\
El Auto 219 de 2011 es un fallo proferido por la Corte Constitucional donde se da \\
seguimiento a las ordenes expuestas en la Sentencia T-025 del año 2004, \\
resolución que decreta el Estado de Cosas Inconstitucional, en este sentido, el \\
presente auto manifiesta busca determinar si el goce efectivo de los derechos \\
fundamentales se convierten en el problema mayor, o si por el contrario, reposa en \\
la superación de los conflictos detallados en la Sentencia T-025/2004, hechos que \\
deben ser dirimidos con la intermediación de las instituciones jurídicas. La Corte \\
Constitucional decide realizar una intervención de manera sintética y recopilada que \\
permita dar a conocer los efectos, los logros, las falencias, las implementaciones \\
de las políticas públicas y demás que se han producido de conformidad a la vigencia \\
resolutoria de la sentencia ya mencionada. \\
Es necesario mencionar que esta sustentación efectuada por la Corte \\
Constitucional se basa en los informes presentados por el Gobierno Nacional el día \\
16 de marzo del año 2011 , así mismo de las evaluaciones y el informe de gestiones \\
y resultados alcanzados por el Gobierno Nacional en el periodo comprendido entre \\
el año 2004 y 2010, estos contrahechos han sido remitidos a la Corte \\
\hline
\end{tabular}


Constitucional, la Comisión de Seguimiento, Organizaciones no Gubernamentales, Organizaciones Internacionales, Centros Académicos y Organizaciones que velan por la protección de las personas que han sido víctimas del desplazamiento forzado.

Respecto al fortalecimiento de la capacidad institucional, la Corte Constitucional señaló que a partir del 2004 hasta enero del 2009, el avance del gobierno para superar el Estado de Cosas Inconstitucionales fue mínimo, pues si bien es cierto este era el eje central, se seguía perturbando de manera consecutiva los derechos fundamentales y por ende el surgimiento del desplazamiento forzado, así mismo replicó que para la época no exista mecanismo alguno para determinar de manera exacta cual era la naturaleza que producía esta gran falencia por parte del Gobierno Nacional, razón por la cual el Estado afrontaba una serie de factores que inhibían la superación del mismo, toda vez que no existían las herramienta para indagar o cuestionar el nacimiento que invalidaba la superación del Estado de Cosas de Inconstitucionalidad.

Es así, que ante estos hechos el informe realizado el día 1 de Julio del año 2010, expresó la necesidad de crear un grupo de trabajo en la unidad de desarrollo de política pública, institución que sería la encargada de superar las falencias descritas. Este plan de mejoramiento se basa en la orientación y el fortalecimiento sustantivo de tres lineamientos accionantes que surgen a partir del 1 de enero del año 2009: "1) La reestructuración del modelo de operación del Sistema de Atención Integral a la Población víctima del Desplazamiento Forzado para establecer procesos y procedimientos, recursos; 2) El fortalecimiento de la gestión de los procesos internos de las 28 entidades integrantes del SNAIPD (racionalizar oferta institucional, incrementar cobertura de los programas y servicios de su competencia, ampliar y mejorar efectividad de espacios de participación para organizaciones de población desplazada; y 3) La integración y fortalecimiento de la coordinación y articulación del nivel nacional del SNAIPD con las entidades territoriales, encaminado a mejorar la articulación e integración entre políticas y planes nacionales"

\section{Consideraciones}

La Corte Constitucional manifiesta que desde la formulación de planes a partir del año 2009, los resultados para superar el Estado de Cosas Inconstitucional han sido muy bajos y por ende no están siendo eficaces, de manera tal que se refleja la incapacidad del Estado para asegurar el goce efectivo de los derechos fundamentales, ante esta circunstancia surge el proyecto de ley de victimas que da origen a la Ley 1448 de 2011, normatividad que tiene como objetivo primordial la restitución de tierras que han sido abandonadas o despojadas.

En relación al esfuerzo presupuestal, el Gobierno Nacional presentó un marco referencial que señala los gastos financieros en beneficio al desplazamiento forzado, manifestando: "la Nación ha multiplicado casi 10 veces los recursos destinados a la población desplazada al comparar lo destinado en el período 19992002 ( $\$ 543.109$ millones de pesos de 2010) con el período 2007-2010 ( $\$ 5.3$ billones de pesos de 2010)". De acuerdo a lo señalado por el Gobierno Nacional y por la 
Contraloría General de la República al argumentar que el " $89 \%$ de los recursos fiscales se estaban destinando al plan del Sistema Nacional de Atención Integral a la Población Desplazada (SNAIPD)", la Corte Constitucional determinó que a pesar de los esfuerzos económicos los resultados para superar el Estadio de Cosas Inconstitucionales ha sido ineficaz, que por el contrario se ha generado un decremento patrimonial.

Por otro lado, la Defensoría del Pueblo expresa una gran inquietud e incertidumbre con el presupuesto designado para este plan, al señalar que el término para acceder a la ayuda humanitaria es prorrogable de manera automática e indefinida, así mismo los límites de incapacidad que tiene la entidad Acción Social antes las diversas dificultades de tipo económico para prestar los servicios requeridos a los desplazados por la violencia, la falta de atención, protección, educación para niños, niñas y adolescentes, son problemas que se deben dirimir de manera clara y precisa.

En este sentido, la Corte Constitucional asume que efectivamente se ha reflejado un incremento presupuestal para ejecutar estos planes, sin embargo, el desplazamiento forzado sigue incrementando. Ante esto la Corte señala que los informes presupuestales presentado por las instituciones jurídicas como; Contraloría General de la República, Defensoría del Pueblo, Procuraduría General de la Nación y demás entes competentes, son inconsistentes y que carecen de una firmeza, claridad y transparencia que son necesarios para determinar la inversión precisa de los recursos del estado.

Ahora bien, se refleja la necesidad de realizar un replanteamiento de la política de tierras. Señala que entre el año 2004 y 2010, los planes de política pública para superar el Estado de Cosas Inconstitucionales no tuvieron eficacia alguna, forjando después del año 2010 una serie de esfuerzos relativos mediante la utilización de mecanismos que permitan superar esta situación socio jurídica.

En el periodo comprendido entre el año 2004 y 2010, no se presentaron avances significativos en materia de desplazamiento forzado, siendo así una debilidad estatal al realizar caso omiso de las situación derivadas para aquellas personas que por circunstancias directas del conflicto armado interno se vieron en la necesidad de abandonar sus tierras, o que por el contrario se les fueron despojadas, presumiendo primordialmente una preocupación respecto a la desmovilización de personas concernientes a grupos al margen de la ley, y no a la reparación patrimonial o extra patrimonial, por ello, en auto 008 de 2009, la Corte determinó que esa reformulación debería tener como objetivos: "(i). Contar con un mecanismo para esclarecer la verdad de la magnitud, las modalidades y efectos de los abandonos y despojos de tierras ocurridos en el marco del conflicto armado; (ii). Identificar reformas institucionales y normativas que sean necesarias para asegurar la restitución de bienes a la población desplazada; y (iii). Diseñar y poner en marcha un mecanismo especial para recibir, tramitar y resolver las reclamaciones de restitución de tierras de las víctimas de abandonos o despojos". 
De conformidad al auto 008 del año 2009, se presume que el Gobierno Nacional no adoptó las medidas necesarias para el uso y goce legítimo de los derechos fundamentales, y que en caso de la incesante vulneración de los mismos se denota la inexistencia de un medio eficaz para reparar íntegramente a las víctimas, reparación que debe ser basada primordialmente en la restitución de tierras.

Con el fin de establecer parámetros proporcionales a la realidad, se realiza un informe basado en la devolución de tierras acorde al procedimiento descrito en la Ley de Justicia y Paz, presentación que trae consigo la adecuación de los siguientes datos: "El $69.6 \%$ de los hogares abandonaron algún predio en el desplazamiento; la relación jurídica con el bien es en su mayoría informal, menos del $40 \%$ tiene propiedad con título (sin especificar cuál); de estos, sólo el $43.9 \%$ declararon los bienes abandonados. En el $34 \%$ de hogares que iniciaron procesos de restitución, el $69.3 \%$ pasaron documentos y en el $30.7 \%$ de los casos se congeló el predio". En vista de lo anterior, la Corte Constitucional expresó que la Ley de Justicia y Paz, ha sido ineficaz respecto al punto de restitución de tierras, anómalo que es primordial para la superación del Estado de Cosas Inconstitucionales, así mismo la Corte determinó que un gran porcentaje de predios no cumplía con los requisitos legales al no tener la documentación respectiva a efecto de demostrar la titularidad del dominio o el modo de adquisición.

Con el fin de garantizar el goce efectivo del derecho a la propiedad, la seguridad, la reparación y demás derechos, se replantea una política pública donde las personas que tengan la calidad de victima puedan acceder a la devolución de sus tierras, independientemente del modo de adquisición, es decir, si son propietarios, poseedores, ocupantes o tenedores, pues para cada caso específico hay una serie de elementos probatorios que se pueden utilizar a favor de estos.

La Corte Constitucional manifiesta que hasta la presente no se ha logrado alcanzar el goce efectivo de los derechos fundamentales y por ende la protección y reparación en un $100 \%$, razón por la cual persiste el Estado de Cosas Inconstitucionales, esto a pesar de los esfuerzos financieros, planes de desarrollo, cumplimiento de cronogramas, procedimientos e incluso la innovación de nuevas figuras jurídicas, toda vez que reposa en un presupuesto y procedimiento que no son claros, eficaces y transparentes.

\begin{tabular}{|l|l|}
\hline Decisión & $\begin{array}{l}\text { Constatar que percibe el Estado de } \\
\text { Cosas Inconstitucionales. }\end{array}$ \\
\hline
\end{tabular}

Respecto de esta jurisprudencia y en relación con el estándar de reparación podríamos afirmar que para determinar el cumplimiento de dicho estándar es necesario primero, i) identificar los presupuestos generales de admisibilidad del Estatuto de Roma de cara a la capacidad del Estado Colombiano para investigar los crímenes, juzgar y sancionar a 
los responsables en el marco de la ley de justicia y paz; posteriormente ii) el principio de complementariedad se encuentra contemplado en el preámbulo del ER, en su artículo 114 y se desarrolla en su artículo 17. Puede definirse de manera sencilla como la oportunidad que tienen los Estados para que sean sus propias jurisdicciones las que investiguen, juzguen y sancionen a los responsables de graves crímenes que están enmarcados en la competencia de la CPI. Si los Estados cumplen con esta obligación, la CPI no se encuentra facultada a actuar.

\subsection{El derecho a la Reparación a las víctimas de graves violaciones al DIH y al DIDH}

El artículo 3ํ de la Ley 1448 de 2011, hace una caracterización genérica de la condición de víctima, y el mismo les atribuye reconocimiento temporal a partir de 1985, y su condición se establece a partir de haber sido víctimas de flagrantes violaciones a las regulaciones del Derecho Internacional Humanitario o a los Instrumentos Internacionales de Protección de Derechos Humanos. Todo ello en el marco del desarrollo del conflicto armado interno. La ley reconoce el derecho a la reparación a las víctimas derivadas de lo estipulado en la Constitución Política de Colombia, en las sentencias y pronunciamientos de los organismos internacionales de Protección de Derechos Humanos y los desarrollos e interpretaciones que de los mismos han hecho tanto la Corte Constitucional como el Consejo de Estado (Congreso de la República de Colombia, 2011). La Ley 1448 acoge en términos generales lo establecido por la Corte Constitucional y la Corte Interamericana de Derechos Humanos $\mathrm{CIDH}$, al puntualizar 
tanto axiológica como temporalmente el concepto de víctima de los siguientes términos (Garay Salamanca, 2013b).

En primer término, resulta claro que, la jurisprudencia en Colombia del máximo tribunal constitucional, se ha convertido en un referente ineludible para establecer el contenido normativo del derecho a la reparación y para sistematizar el conjunto de obligaciones jurídicamente exigibles al Estado para su protección y realización (DEFENSORÍA DEL PUEBLO - GIZ. (Deustche Gesellschaff für Internationale Zusammnarbeit GIZ Gmbh) , 2012a). En segundo término y respecto del alcance material del derecho a la reparación tenemos que el caso colombiano, la dogmática de las fuentes normativas del derecho internacional en relación con el interno, se circunscribe al concepto de Bloque de Constitucionalidad que ha sido desarrollado por la Corte Constitucional a partir de la sentencia C-225 de 1995 y desarrollado por su amplia jurisprudencia, como un intento para acercar las premisas jurídicas internacionales de protección de los derechos humanos y compaginarlos con el ordenamiento jurídico interno. El Bloque de Constitucionalidad es una herramienta jurisprudencial en virtud de la cual todos los tratados internacionales que hayan sido ratificados por el Estado Colombiano en materia de protección de Derechos Humanos y Derecho Internacional Humanitario quedan inmediatamente integrados al texto de la Constitución Política y por tal vía la observancia y el cumplimiento de estos, que pueden ser exigibles judicial y administrativamente en el orden interno (Uprimny, 2006c). 
Uno de los fundamentos del Bloque de Constitucionalidad se encuentra expuesto en el artículo 93 constitucional y a su vez a lo largo de varios artículos adicionales insertos en el texto de la constitución, en tal sentido, el artículo 250 reconoce el derecho a la reparación integral, gracias a que el mismo sostiene: "En ejercicio de sus funciones la Fiscalía General de la Nación deberá: (...). Solicitar ante el juez de conocimiento las medidas judiciales necesarias para la asistencia a las víctimas, lo mismo que disponer el restablecimiento del derecho y la reparación integral a los afectados con el delito". (Subrayado fuera de texto). Con arreglo en estas disposiciones, el tribunal constitucional ha adelantado el marco jurisprudencial que fundamenta el derecho a la reparación integral. En la Sentencia T - 458 de 2010. La Corte reiteró una línea jurisprudencial en la que postula el derecho a la reparación en los siguientes términos.

"La Corte ha reiterado que el Estado tiene la obligación constitucional de proteger los derechos de las víctimas de hechos punibles. Así se desprende del deber de las autoridades de propender por el goce efectivo de los derechos de todos los residentes en Colombia (Art 2 C.N), del principio de dignidad humana (Art. 1 C.N), del derecho de acceso a la administración de justicia (Art. 229 C.N) y del deber de asistencia que tiene el Fiscal General de la Nación respecto de las víctimas dentro del proceso penal (Art. 250 C.N). Estos derechos hacen parte de un amplio catálogo que tiene como 'columna vertebral' los derechos a la verdad, la justicia y la reparación. Ellos 'se erigen como bienes cardinales de toda sociedad que se funde en un orden justo y de pacífica convivencia, entre los cuales median relaciones de conexidad e interdependencia, de manera tal que: No es posible lograr la justicia sin la verdad. No es posible llegar a la reparación sin la justicia" (T-458/2010 Corte Constitucional de Colombia, 2010). 
En relación con el marco interpretativo del derecho a la reparación, la Corte sostiene de forma homogénea en su jurisprudencia que este derecho debe ser interpretado de acuerdo con el contenido de los tratados internacionales integrados al texto constitucional por vía del Bloque de Constitucionalidad. (T-458/2010 Corte Constitucional de Colombia, 2010). Es decir, cualquier interpretación que sea realizada en el momento de aplicar los estándares internos del derecho cuya titularidad reside en las víctimas del conflicto armado, debe estar estrictamente ligada con los desarrollos jurisprudenciales descritos por la Corte Constitucional al integrar la normatividad convencional internacional al ordenamiento interno. Por ello, el gobierno nacional reconoce en el texto de presentación de la Ley 1448 de 2011 lo siguiente: "La Ley de Víctimas y Restitución de Tierras, así como los decretos con fuerza de ley que reglamentan las medidas de asistencia, atención y reparación integral a los grupos étnicos, representan un notable esfuerzo que se estructura sobre la base de los estándares y principios internacionales que rigen la materia" (Ley 1448 de 2011, p.11) (Subrayado fuera del texto).

De otro lado, y siguiendo lo dispuesto por el tribunal constitucional, se tiene que, en el orden interno, el estándar de análisis y aplicación del derecho a la reparación está constituido por lo dispuesto en los siguientes tratados ratificados por el Estado Colombiano e integrados al Bloque de Constitucionalidad. 1. El Pacto internacional de Derechos Civiles y Políticos, ratificado por el Estado Colombiano en 1966 y quien en su artículo 9.5 estipula. "Toda persona que haya sido ilegalmente detenida o presa, tendrá el derecho efectivo a obtener reparación". 2. La Convención Americana sobre Derechos 
Humanos, de 1969 que señala en sus artículos 10 y 63. "Derecho a Indemnización. Toda persona tiene derecho a ser indemnizada conforme a la ley en caso de haber sido condenada en sentencia firme por error judicial. (...) Art. 63. Cuando decida que hubo violación de un derecho o libertad protegidos en esta Convención, la Corte dispondrá que se garantice al lesionado en el goce de su derecho o libertad conculcados. Dispondrá, asimismo, si ello fuera procedente, que se reparen las consecuencias de la medida o situación que ha configurado la vulneración de esos derechos y el pago de una justa indemnización a la parte lesionada". 3. Convención contra la Tortura y Otros Tratos o Penas Crueles, Inhumanos o Degradantes de1984. Que sostiene en su artículo 141. "Todo Estado Parte velará porque su legislación garantice a la víctima de un acto de tortura la reparación y el derecho a una indemnización justa y adecuada, incluidos los medios para su rehabilitación lo más completa posible. En caso de muerte de la víctima como resultado de un acto de tortura, las personas a su cargo tendrán derecho a indemnización". 4. La Convención sobre los Derechos del Niño que estipula en su artículo 39. “Los Estados Partes adoptarán todas las medidas apropiadas para promover la recuperación física y psicológica y la reintegración social de todo niño víctima de: cualquier forma de abandono, explotación o abuso; tortura u otra forma de tratos o penas crueles, inhumanos o degradantes; o conflictos armados. Esa recuperación y reintegración se llevarán a cabo en un ambiente que fomente la salud, el respeto de sí mismo y la dignidad del niño".

También entran en este marco las normas del Derecho Internacional Humanitario y los Instrumentos del Derecho Penal Internacional, empezando por el Estatuto de Roma de 
1999 que le dio vida a la Corte Penal Internacional. 5 estatuto de la Corte Penal Internacional, quien en su artículo 75 dispone. "Reparación a las víctimas. 1. La Corte establecerá principios aplicables a la reparación, incluidas la restitución, la indemnización y la rehabilitación, que ha de otorgarse a las víctimas o a sus causahabientes. Sobre esta base, la Corte, previa solicitud o de oficio en circunstancias excepcionales, podrá determinar en su decisión el alcance y la magnitud de los daños, pérdidas o perjuicios causados a las víctimas o a sus causahabientes, indicando los principios en que se funda". 6 La Convención de La Haya relativa a las leyes y costumbres de la guerra terrestre que sostiene en su artículo 3. "La parte beligerante que viole las disposiciones de dicho Reglamento estará obligada a indemnización, si fuere el caso, y será responsable de todos los actos cometidos por las personas que hagan parte de su fuerza armada". Y, por último, El Protocolo Adicional a los Convenios de Ginebra del 12 de agosto de 1949, relativo a la Protección de las Víctimas de los Conflictos Armados Internacionales (Protocolo I) quien en su artículo 91 dispuso que: "Responsabilidad. La Parte en conflicto que violare las disposiciones de los Convenios o del presente Protocolo estará obligada a indemnizar si hubiere lugar a ello. Será responsable de todos los actos cometidos por las personas que formen parte de sus fuerzas armadas". Estos instrumentos internacionales son de estricto cumplimiento para el Estado Colombiano, no obstante, y en virtud de lo dispuesto por el Articulo 25 de la Carta de las Naciones Unidas, algunas de las resoluciones expedidas por el Consejo de Seguridad de este organismo internacional también son de obligatorio cumplimiento en materia de interpretación del derecho a la reparación (Deustche Gesellschaff für Internationale Zusammnarbeit GIZ Gmbh, 2012b). Teniendo en cuenta que estos instrumentos hacen 
parte del denominado Soft Law o derecho blando, y que su naturaleza jurídica es distinta de la de los tratados, sin embargo en materia de criterios generales de interpretación estas disposiciones son enteramente válidas y han sido empleadas tanto por la Corte Constitucional como por la Comisión y la Corte Interamericana de Derechos Humanos en sus actuaciones y pronunciamientos, así incluso lo estableció la propia Corte Constitucional en la sentencia C - 872 de 2003 (Ramelli, 2003).

En tal sentido los documentos provenientes del Soft Law que forman parte del grupo de instrumentos de este derecho relativos al derecho a la reparación, son los siguientes: 1. Conjunto de principios para la protección y promoción de los derechos humanos mediante la lucha contra la impunidad. 2. Principios y directrices básicas sobre el derecho de las víctimas de violaciones manifiestas de las normas internacionales de derechos humanos y de violaciones graves del derecho internacional humanitario a interponer recursos y obtener reparaciones. Aprobados por la Comisión de Derechos Humanos mediante resolución 2005/35 del 19 de abril de 2005 y el 16 de diciembre de 2005 por la Asamblea General de la ONU (Deustche Gesellschaff für Internationale Zusammnarbeit GIZ Gmbh, 2012c). 3. Principios rectores de los desplazamientos internos. 4. Principios sobre la restitución de las viviendas y el patrimonio de los refugiados y las personas desplazadas. 5. Declaración sobre los principios fundamentales de justicia para las víctimas de los delitos y de abuso de poder. Adoptada por la Asamblea General de Naciones Unidas, mediante resolución 40/34 del 29 de noviembre de 1985. 6. Declaración sobre la protección de todas las personas contra las desapariciones forzadas. Adoptada por la Asamblea General de Naciones Unidas, mediante resolución 
47/133 del 18 de diciembre de 1992. No obstante, su carácter auxiliar y hemático, estos principios son relevantes en tanto sirven de contexto e interpretación en materia de precisión y alcance del derecho a la reparación. Su misma naturaleza no implica obligaciones nuevas para los Estados sin embargo los mismos recogen importantes avances en materia de Derechos Humanos y Derecho Internacional Humanitario por lo que han sido observados y tenidos en cuenta por los tribunales internacionales para establecer el marco y los alcances del derecho y la obligación de reparación (Hernández, 2012).

En materia jurisprudencial la Corte Constitucional ha delimitado el contenido del Derecho a la Reparación a partir de su jurisprudencia, en primer término y con la promulgación de la icónica sentencia T - 025 de 2004 el máximo tribunal constitucional de Colombia sostuvo que los ciudadanos víctimas del desplazamiento forzado como consecuencia del desarrollo del conflicto armado son a su vez víctimas de un grave delito (PROCURADURÍA GENERAL DE LA NACIÓN , 2007). Razón por la cual son titulares de los derechos a la justicia, la reparación, la verdad y adicionalmente son titulares de las garantías de no repetición, además de la declaratoria del Estado de Cosas Inconstitucional descrito por la sentencia y los más de 50 autos de seguimiento a la misma (Deustche Gesellschaff für Internationale Zusammnarbeit GIZ Gmbh, 2012d). A su vez los cambios normativos surtidos por el nuevo sistema penal acusatorio y la inclusión de los derechos de las víctimas en el mismo con lo que algunos autores han denominado la constitucionalización de los derechos de las víctimas en el marco del proceso penal (González, 2013). 
Adicionalmente a la expedición de la Ley 975 de 2005, por medio de la cual el gobierno nacional adoptó disposiciones para permitir la reincorporación a la vida civil de los miembros de los grupos paramilitares y en general de las demás organizaciones armadas al margen de la ley, este derecho tuvo una materialización mucho más concreta y un alcance más específico con la expedición del Decreto 1290 de 2008 mediante el cual se creó el programa de reparación individual por vía administrativa (Patiño, 2006). Tras la expedición de estos dos instrumentos normativos, se desataron fuertes cuestionamientos contra los mismos de forma que la Corte Constitucional, tanto por vía de tutela como por vía de la Acción Publica de Inconstitucionalidad, tuvo un alto número de pronunciamientos que sirvieron para consolidar una línea argumental que precisó el alcance material del derecho a las víctimas en el ordenamiento interno (Defensoría del Pueblo, 2012).

En suma, pese a las falencias del Sistema de Justicia y Paz concebido con la emisión de la Ley 975 de 2005, resulta destacable que el mismo legislador haya emitido otra serie de normativas que procuren concretamente la materialización de los derechos de las víctimas, especialmente; así como la labor armónica del poder judicial al respecto, a través de los pronunciamientos de la Corte Constitucional, para corregir y acomodar el proceso a los estándares internacionales de reparación de las víctimas, detectando fallas en su ejecución, imponiendo obligaciones al gobierno, al legislador y procurando el cumplimiento de las máximas de verdad, reparación, no impunidad y no repetición, teniendo como sujeto primordial a quien resultó vulnerado por el conflicto armado, para 
que finalmente se satisfagan los principios del proceso y no sea necesaria la intervención de un tribunal externo.

\subsection{El Consejo de Estado y su papel en la reparación a víctimas en cumplimiento} de estándares internacionales de reparación

Pues bien, también el máximo tribunal de lo contencioso administrativo, ha jugado un papel primordial a la hora de interpretar y desarrollar las máximas de justicia transicional en curso de los procesos en lo que las víctimas demandan la indemnización del estado por vía judicial a través de la acción de reparación directa Consejo de Estado - Sala de lo Contencioso Administrativo - Sección Tercera, sentencia de unificación jurisprudencial del 28 de agosto de 2014, Exp. 26.251, M.P. Jaime Orlando Santofimio Gamboa. Consejo de Estado - Sala de lo Contencioso Administrativo - Sección Tercera, sentencia de unificación jurisprudencial del 28 de agosto de 2014, Exp. 27709, M.P. Carlos Alberto Zambrano. Consejo de Estado - Sala de lo Contencioso Administrativo - Sección Tercera, sentencia de unificación jurisprudencial del 28 de agosto de 2014, Exp. 32988, M.P. Ramiro Pazos Guerrero. Consejo de Estado - Sala de lo Contencioso Administrativo - Sección Tercera, sentencia de unificación jurisprudencial del 28 de agosto de 2014, Exp. 31172, M.P. Olga Mélida Valle de la Hoz. Consejo de Estado Sala de lo Contencioso Administrativo - Sección Tercera, sentencia de unificación jurisprudencial del 28 de agosto de 2014, Exp. 36149, M.P. Hernán Andrade Rincón, Consejo de Estado - Sala de lo Contencioso Administrativo - Sección Tercera, sentencia de unificación jurisprudencial del 28 de agosto de 2014, Exp. 28804, M.P. Stella Conto Díaz del Castillo. Consejo de Estado - Sala de lo Contencioso Administrativo - Sección Tercera, sentencia de unificación jurisprudencial del 28 de agosto de 2014, Exp. 31170, M.P. Enrique Gil Botero. Consejo de Estado - Sala de lo Contencioso Administrativo Sección Tercera, sentencia de unificación jurisprudencial del 28 de agosto de 2014, Exp. 28832, M.P. Danilo Rojas Betancourth). 
El Tribunal Contencioso Administrativo en sus pronunciamientos consideró que el juez de daños como juez de convencionalidad en el ordenamiento jurídico, tiene la facultad para revisar el cumplimiento de las obligaciones de respeto y garantía de los derechos humanos por parte de las autoridades públicas internas. El control de convencionalidad consiste en la constatación objetiva de cumplimiento de las obligaciones internacionales por parte del juez en caso de concretarse un daño antijurídico que pueda ser imputable al Estado por la posible abstención de una obligación de hacer. El juez parte de estándares de origen internacional, de normas supralegislativas en las que se hayan las obligaciones vinculantes a cargo del Estado que tendrá en cuenta en la interpretación con el fin de analizar la conducta de los agentes estatales a la luz de obligaciones internacionales y nacionales.

Se establecen tablas acerca de la reparación del daño moral en caso de muerte, en caso de lesiones personales y en caso de privación injusta de la libertad; también de reparación no pecuniaria por afectación o vulneración relevante de bienes o derechos convencionales y constitucionalmente amparados, de indemnización excepcional para la víctima directa en caso de violación de bienes o derechos convencional y constitucionalmente amparados, y de reparación del daño a la salud.

La Sección Tercera del Consejo de Estado reconoce tres tipos de perjuicios inmateriales:

1. Perjuicio moral: compuesto por el dolor, aflicción, congoja, sentimientos de desesperación, desasosiego, temor, zozobra, que invaden a la víctima directa o indirecta de un daño antijurídico, individual o colectivo.

1.1. Daño moral en caso de lesiones personales.

1.2. Daño moral en caso de privación injusta de la libertad (Consejo de Estado - Sala de lo Contencioso Administrativo - Sección Tercera - Rad. 25.022). 
2. Daño inmaterial por afectación relevante a bienes o derechos convencional y constitucionalmente amparados. Se trata de vulneraciones o afectaciones relevantes, las cuales producen un efecto dañoso, negativo y antijurídico a bienes constitucionales y convencionales. Es un daño autónomo, no depende de otras categorías de daños porque no está condicionado a la configuración de otros tradicionalmente reconocidos; puede ser temporal o definitivo, los efectos se manifiestan en el tiempo, de acuerdo al grado de intensidad de la afectación, esto es, el impedimento para la víctima directa e indirecta de gozar y disfrutar plenamente sus derechos constitucionales y convencionales. La reparación, que generalmente es de carácter no pecuniario, está dirigida a restablecer a la víctima en el ejercicio de sus derechos, lograr que desaparezcan las causas de lesividad, propender para que en el futuro no tenga lugar la vulneración, buscar la realización de la igualdad sustancial. Las medidas de reparación al respecto también operan de oficio

3. Daño a la salud (perjuicio fisiológico o biológico) derivado de una lesión corporal o psicofísica: Se tendrán en cuenta los criterios de la sentencia de unificación del 14 de septiembre de 2011, exp. 19031 de la Sección Tercera del Consejo de Estado

Para la reparación del daño moral se diseñaron topes indemnizatorios y cinco niveles de cercanía afectiva entre la víctima directa y las víctimas indirectas, que son aquellas que acuden a la justicia en calidad de perjudicados, de acuerdo a su relación afectiva, conyugal, consanguínea.

Se prevé que, para todos los casos de daños morales, en casos excepcionales como los de graves violaciones a los derechos humanos, pueda otorgarse una indemnización mayor de la señalada en las tablas, cuando existan circunstancias debidamente probadas de mayor intensidad y gravedad del daño moral, sin que la indemnización supere el triple de los montos indemnizatorios señalado, lo cual deberá ser debidamente motivado por el operador jurídico y ser proporcional a la intensidad del daño. 
Para la reparación de afectación o vulneración relevante de bienes o derechos convencional y constitucionalmente amparados se prevén medidas de reparación integral no pecuniarias de acuerdo a los hechos probados, la oportunidad y pertinencia de los mismos en favor de la víctima directa y su núcleo familiar más cercano, excepcionalmente se reconocerá una indemnización única y exclusiva a la víctima directa de $100 \mathrm{smlmv}$.

Para la reparación del daño a la salud se tendrá en cuenta la gravedad de la lesión corporal o física debidamente probada dentro del proceso, es decir, su porcentaje, las consecuencias de la enfermedad o accidente que reflejen alteraciones al nivel de comportamiento y desempeño de la persona dentro de su entorno social, teniendo en cuenta la pérdida o anormalidad de la estructura o función psicológica, fisiológica o anatómica, la anomalía producida en un miembro, órgano, tejido u otra estructura corporal o mental, la exteriorización de un estado patológico que refleje perturbaciones, la reversibilidad o irreversibilidad de la patología, restricción o ausencia de la capacidad para realizar una actividad normal, entre otros. Excepcionalmente cuando existan circunstancias de mayor intensidad puede otorgarse una indemnización de $400 \mathrm{smlmv}$

Otro tema de gran importancia desarrollado a través de la jurisprudencia contencioso administrativa para las víctimas y el cumplimiento de los estándares internacionales en materia de reparación, ha sido la caducidad para delitos de lesa humanidad. La Carta Política en su artículo 228 determina la aplicación de los términos procesales a fin de proteger materialmente los derechos, el interés general y la seguridad jurídica. Se estableció entonces la caducidad como norma de orden público irrenunciable y término de expiración perentorio para ejercer las acciones judiciales contencioso administrativas por los perjuicios causados a un grupo y las derivadas de los actos, hechos, omisiones y operaciones provenientes de las autoridades públicas (Código de Procedimiento Administrativo y de lo Contencioso Administrativo, artículo 164, núm. 2º, literales h y j): 
h) Cuando se pretenda la declaratoria de responsabilidad y el reconocimiento y pago de indemnización de los perjuicios causados a un grupo, la demanda deberá promoverse dentro de los dos (2) años siguientes a la fecha en que se causó el daño. Sin embargo, si el daño causado al grupo proviene de un acto administrativo y se pretende la nulidad del mismo, la demanda con tal solicitud deberá presentarse dentro del término de cuatro (4) meses contados a partir del día siguiente al de la comunicación, notificación, ejecución o publicación del acto administrativo;

i) Cuando se pretenda la reparación directa, la demanda deberá presentarse dentro del término de dos (2) años, contados a partir del día siguiente al de la ocurrencia de la acción u omisión causante del daño, o de cuando el demandante tuvo o debió tener conocimiento del mismo si fue en fecha posterior y siempre que pruebe la imposibilidad de haberlo conocido en la fecha de su ocurrencia.

Así las cosas, se tiene un límite temporal para que los ciudadanos ejerzan el derecho de acción y reclamen al Estado la reparación de los perjuicios ocasionados, de manera tal que si no se activa el aparato judicial dentro de tales términos no puede ser objeto de protección y el operador judicial se encuentra legitimado para desestimar la demanda de plano (Corte Constitucional sentencias SC-351 de 1994, SC-418 de 1994, SC-115 de 1998, C-781 de 1999, C-565 de 2000).

No obstante, la normativa internacional, y la doctrina de Tribunales nacionales e internacionales, imponen que en materia de Derechos Humanos sea atemporal el juzgamiento de las conductas constitutivas de lesa humanidad; el artículo 93 de la Constitución Política, los artículos 8.1 y 25 de la Convención Americana de Derechos Humanos se armonizan al momento analizar la demanda de responsabilidad del Estado en ese tipo de casos.

Constitución Política, articulo 93. Los tratados y convenios internacionales ratificados por el Congreso, que reconocen los derechos humanos y que prohíben su limitación en los estados de excepción, prevalecen en el orden interno. 
Los derechos y deberes consagrados en esta Carta, se interpretarán de conformidad con los tratados internacionales sobre derechos humanos ratificados por Colombia.

El Estado Colombiano puede reconocer la jurisdicción de la Corte Penal Internacional en los términos previstos en el Estatuto de Roma adoptado el 17 de julio de 1998 por la Conferencia de Plenipotenciarios de las Naciones Unidas y, consecuentemente, ratificar este tratado de conformidad con el procedimiento establecido en esta Constitución.

La admisión de un tratamiento diferente en materias sustanciales por parte del Estatuto de Roma con respecto a las garantías contenidas en la Constitución tendrá efectos exclusivamente dentro del ámbito de la materia regulada en él.

\section{Convención Americana de Derechos Humanos, artículo 8. Garantías Judiciales}

1. Toda persona tiene derecho a ser oída, con las debidas garantías y dentro de un plazo razonable, por un juez o tribunal competente, independiente e imparcial, establecido con anterioridad por la ley, en la sustanciación de cualquier acusación penal formulada contra ella, o para la determinación de sus derechos y obligaciones de orden civil, laboral, fiscal o de cualquier otro carácter.

\section{Convención Americana de Derechos Humanos, artículo 25. Protección Judicial}

1. Toda persona tiene derecho a un recurso sencillo y rápido o a cualquier otro recurso efectivo ante los jueces o tribunales competentes, que la ampare contra actos que violen sus derechos fundamentales reconocidos por la Constitución, la ley o la presente Convención, aun cuando tal violación sea cometida por personas que actúen en ejercicio de sus funciones oficiales. 
2. Los Estados partes se comprometen:

a. a garantizar que la autoridad competente prevista por el sistema legal del Estado decidirá sobre los derechos de toda persona que interponga tal recurso;

b. a desarrollar las posibilidades de recurso judicial, $y$

c. a garantizar el cumplimiento, por las autoridades competentes, de toda decisión en que se haya estimado procedente el recurso.

Según las fuentes citadas, al demandarse al Estado a través de los mecanismos de acción de grupo y de reparación directa con ocasión de conductas atentatorias de los Derechos Humanos, el operador judicial no debe efectuar el estudio de caducidad de la acción con fundamento estricto en las normas de carácter nacional.

Según la Sala de lo Contencioso Administrativo - Sección Tercera del Consejo de Estado, Auto 85001233100020100017801 (47671), del 7 de septiembre de 2015, la existencia de daño antijurídico con ocasión de actos de lesa humanidad, estos no tienen caducidad ya que no aplica el tratamiento procesal riguroso del ordenamiento jurídico interno que impone reglas temporales limitativas para incoar la acción de reparación directa, ello en virtud de la superioridad de intereses y valores en contraposición del principio de seguridad jurídica.

En la decisión mentada se trae a colación la decisión de la Corte Interamericana de Derechos Humanos en el caso Almonacid Arellano c. Chile, del 26 de septiembre de 2006, según la cual:

"En efecto, por constituir un crimen de lesa humanidad, el delito cometido en contra del señor Almonacid Arellano, además de ser inamnistiable, es imprescriptible. Como se señaló en los párrafos 105 y 106 de esta Sentencia, los crímenes de lesa humanidad van más allá de lo tolerable por la comunidad internacional y ofenden a la humanidad toda. El daño que tales crímenes ocasionan permanece vigente para la sociedad nacional y para la comunidad internacional, las que exigen la investigación y el castigo de los responsables. En 
este sentido, la Convención sobre la imprescriptibilidad de los crímenes de guerra y de los crímenes de lesa humanidad18 claramente afirmó que tales ilícitos internacionales "son imprescriptibles, cualquiera que sea la fecha en que se hayan cometido".

El máximo Tribunal de lo Contencioso Administrativo define en su decisión los crímenes de lesa humanidad como conductas que niegan la dignidad del ser a través de la degradación y genera graves afectaciones a quien lo padece y al colectivo humano, en sus palabras, "actos ominosos que niegan la existencia y vigencia imperativa de los Derechos Humanos en la sociedad". Los elementos estructuradores del concepto de lesa humanidad son i) que el acto se ejecute o lleve a cabo contra la población civil y ii) que ello ocurra en el marco de un ataque generalizado o sistemático.

La jurisprudencia nacional ha dado relevancia al concepto de lesa humanidad, como categoría de gravedad social, para predicar la imprescriptibilidad que las acciones de reparación que se derivan de ese tipo de actos por su connotación y magnitud, por tanto, el paso del tiempo no afecta de manera alguna el derecho de acceso a la administración de justicia, a diferencia de la aplicación estricta de la institución de la caducidad en las demandas de intereses particulares o subjetivos (Corte Constitucional, Auto de 17 de septiembre de 2013, exp. 45092)

En suma, las instituciones de interpretación normativa han estado prestas al cumplimiento de los estándares internacionales de Justicia, Verdad, Reparación y no Repetición que emanan del derecho internacional; así se ha extraído al juez de su ámbito local para que aplique, no solo las normas de carácter nacional, sino que satisfaga las exigencias que el orden mundial ha impuesto para el posconflicto). 


\section{CAPITULO III}

\section{ELEMENTOS DE LA REPARACIÓN EN LA VIGENCIA DE LA LEY DE JUSTICIA Y PAZ}

Luego de trece años de vigencia de la Ley 975 de 2005, por la cual se dictaron disposiciones para la reincorporación de miembros de grupos armados organizados al margen de la ley, que contribuyeran de manera efectiva a la consecución de la paz nacional, el propósito de este capítulo es determinar, desde sus resultados económicos, el grado de satisfacción de los objetivos o fines de Justicia, Verdad, Reparación y No Repetición planteados en esta transcendental norma. Ello por supuesto supone una valoración acerca de si ha sido eficiente su implementación, entendiendo tanto la naturaleza excepcional y transitoria de ese sistema normativo, así también un examen general de la forma en que este se ha aplicado y las consecuencias que tal proceso ha 
producido. Se propone entonces que la herramienta mediante la cual se enfoque el análisis de productividad de la normatividad en mención, sea la variable de "Relación Costo-Beneficio".

Al respecto y de acuerdo a los datos que más adelante se detallarán, en principio y de manera provisional es posible afirmar que de manera cuantitativa no son satisfactorios los resultados que arroja la aplicación de la Ley 975 de 2005; resulta poca la cantidad de sentencias emitidas por las Salas de Justicia y Paz a nivel nacional luego de trece años de vigencia de la norma y miles de recursos invertidos en su ejecución. Tampoco son satisfactorias las cifras reportadas en cuanto a número de postulados con sentencia condenatoria, número de hechos investigados, víctimas que han sido objeto de reparación y número de desaparecidos cuyos cuerpos se han logrado encontrar, identificar y entregar a sus seres queridos.

\subsection{Resultados y costos de la ley de justicia y paz}

Para principios de 2017 la Dirección de Estudios Sectoriales de la Contraloría General de la República publicó el informe: "Análisis de los Resultados y Costos de la Ley de Justicia y Paz", que comprende un riguroso análisis hecho en el periodo transcurrido entre los años 2006 y 2016 y en el que se destaca que el Estado Colombiano ha hecho una astronómica erogación presupuestal con resultados muy exiguos y por entero insatisfactorios, gracias a que de los $\$ 11.1$ billones de pesos que se han gastado en la 
aplicación de la Ley 975 de 2005, en particular, las Salas de Justicia y Paz adscritas a los Tribunales Superiores del Distrito Judicial de: Atlántico, Antioquia y Bogotá han proferido tan solo 47 sentencias, contra 195 postulados, de 2.378 inscritos en el procedimiento que estableció la ley. Es decir, tan solo un $8.2 \%$ de esa población ha sido efectivamente juzgada. Dichas sentencias comprenden 5.401 hechos delictivos y 26.788 víctimas reconocidas, de los 82.114 hechos con imputación de cargos por parte de la Fiscalía y tan solo el $12 \%$ de las 211.013 víctimas relacionadas con estos hechos (Contraloría General de la República, Dirección de Estudios Sectoriales. Análisis de los Resultados y Costos de la Ley de Justicia y Paz, 2017a. Recuperado de http:// www.contraloria.gov.co/documents/20181/466201/Análisis+sobre+los+resultados+y+co $\underline{\text { stos+de+la+Ley+de+Justicia+y+Paz/dcce2907-f669-42b8-8857- }}$ 7e14750cc467? version=1.0).

Según informe presentado por la Sala de Justicia y Paz de Antioquia a la Contraloría General de la República en mayo de 2017 y que recopila datos de carácter nacional, el sistema de justicia de la Ley 975 había emitido 50 sentencias que contemplaban 6.525 hechos delictivos, 206 postulados y 38.034 víctimas reconocidas; teniéndose como promedio que cada sentencia de Justicia y Paz abarca 130 hechos, 506 delitos y 760 víctimas. Justicia y Paz ha emitido 155 decisiones de exclusión y 96 de preclusión al 30 de abril de 2017; las primeras tienen que ver con el incumplimiento de los requisitos y obligaciones de los postulados para acceder a los beneficios de la norma (Tribunal Superior de Antioquia - Sala de Justicia y Paz, Oficio 07 Complemento al informe Análisis sobre resultados de la Ley de Justicia y Paz, 2017). 
Entre 2006 y 2014 ingresaron 4.981 personas a lista de postulados de Justicia y Paz, de ellos 3.915 son desmovilizados y 1.066 privados de la libertad. De esa población, 4.410 postulados provienen de las autodefensas y 571 de las guerrillas FARC y ELN. De los postulados, 3.285 son desmovilizados colectivamente y 630 individuales. De acuerdo con el informe de la Contraloría, la población total que se desmovilizó entre 2002 y 2016 fue de 58.161, con lo que los postulados de Justicia y Paz representan el 6.7\% de ese porcentaje general (Contraloría General de la República, Dirección de Estudios Sectoriales. Análisis de los Resultados y Costos de la Ley de Justicia y Paz, 2017b. Recuperado de http:// www.contraloria.gov.co/documents/20181/466201/Análisis+sobre+los+resultados+y+co $\underline{\text { stos+de+la+Ley+de+Justicia+y+Paz/dcce2907-f669-42b8-8857- }}$ 7e14750cc467? version=1.0).

El periodo que tuvo más postulaciones se encuentra entre 2006 y 2008 con las desmovilizaciones colectivas de las AUC, con 3.585 postulados (72\%), cifra que disminuyó paulatinamente hasta que aumentó con 157 postulaciones en el 2013 cuando la Ley 1592 de 2102 fijó un plazo máximo de un año para acogerse a los beneficios de Justicia y Paz. Se destaca que de toda la población postulada solo 2.603 personas terminaron el proceso de postulación, por lo que el $52,3 \%$ de los postulados salieron de Justicia y Paz, y a noviembre de 2016 se registraban 2.378 postulados activos (47,7\%), de los cuales solo 195 han sido condenados (8.2\% de los activos), 1.704 cuentan con imputación de cargos y 479 están pendientes de ser imputados (Contraloría General de 
la República, Dirección de Estudios Sectoriales. Análisis de los Resultados y Costos de la Ley de Justicia y Paz, 2017c. Recuperado de http:// www.contraloria.gov.co/documents/20181/466201/Análisis+sobre+los+resultados+y+co

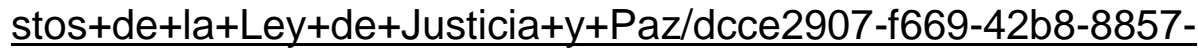

7e14750cc467? version $=1.0$ ).

\subsection{Dificultades y beneficios cualitativos del sistema de justicia y paz}

A la hora de ponderar los resultados de la Ley 975 de 2005, debe considerarse que la Justicia Transicional en modo alguno se circunscribe al trámite de una investigación penal de excepción, esta, nació bajo la complejidad de la historia de los conflictos armados en el Siglo XX y fue consolidada por la experiencia internacional de limitación de los terribles efectos de los mismos. En particular la Justicia Transicional se refiere a una decisión política y jurídica que toman los pueblos luego de abandonar una situación de conflicto armado para adecuar su estructura penal de manera transitoria con el fin de garantizar de un lado, la reincorporación de los combatientes a la vida civil y de otro garantizar los derechos de las víctimas ocasionadas en la confrontación armada (Sánchez, 2013). En este sentido y en el marco de la Ley 975 de 2005 se están investigando, esclareciendo, persiguiendo, juzgando y sancionando los hechos ocurridos en todo el territorio nacional durante décadas de confrontación militar, lo cual dificulta de manera superlativa la obtención de materiales probatorios, la obtención de registros de 
los hechos delictivos e incluso en muchos casos la ubicación de víctimas que se han desplazado a otros lugares del país (Contraloría General de la República, Dirección de Estudios Sectoriales. Análisis de los Resultados y Costos de la Ley de Justicia y Paz, 2017d. Recuperado de http:// www.contraloria.gov.co/documents/20181/466201/Análisis+sobre+los+resultados+y+co

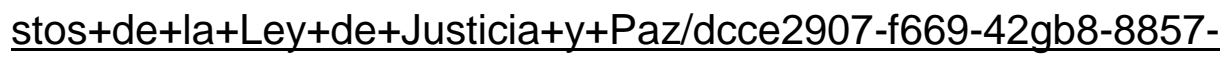
7e14750cc467?version=1.0).

Por lo anterior, el legislador previó como herramienta para agilizar este tipo de investigaciones, la teoría jurídica del contexto, extractada de las jurisprudencia emanada por la Corte Interamericana de Derechos Humanos (CIDH), entendido como el medio por el cual se agrupan hechos y delitos en patrones de macro criminalidad y macro victimización para que no se investigue y juzgue individualmente cada hecho victimizante, sino como un sistema bajo la dinámica del conflicto, los patrones en el accionar de los grupos armados, impactos y estrategias utilizadas que permita identificarlo (Comisión Interamericana de Derechos Huhmanos CIDH , 1997). Así observamos como acápites relevantes en las decisiones de Justicia y Paz la génesis del grupo armado, su modus operandi, territorios de influencia, prácticas utilizadas, redes de apoyo, fuentes de financiación e información, entre otros (Seminario Internacional. Importancia en la construcción de contexto en investigaciones judiciales, 2013).

Este proceso también se complejiza cuando se implementa el incidente de reparación de víctimas, en el que se reconoce y liquida individualmente el daño emergente, el lucro 
cesante, perjuicios de orden moral, el daño a la vida en relación de cada una de las víctimas, además de reparaciones de orden plural y colectivo. Lo anterior implica que además de las funciones relacionadas con la potestad punitiva del Estado, las Salas de Justicia y Paz llevan a cabo una función propia de la Jurisdicción Ordinaria en procesos de responsabilidad civil extracontractual que se realiza de forma concomitante o posterior a la determinación de la responsabilidad penal, que se evacúa de manera concentrada en audiencias que se han llevado a cabo en lugares foco de la barbarie, de difícil acceso y con mayor concentración de víctimas, implicando entonces una labor mancomunada entre la Jurisdicción, la Fiscalía General de la Nación y la Unidad de Atención y Reparación a Víctimas para reunir la mayor cantidad de víctimas y sus perpetradores (Tribunal Superior de Antioquia - Sala de Justicia y Paz, Oficio 07 Complemento al informe Análisis sobre resultados de la Ley de Justicia y Paz, 2017).

Obsérvese además, que según el ente de control, el pago de las indemnizaciones del sistema ha sido cubierto en su mayoría con recursos del Presupuesto General de la Nación; con lo que se vislumbra que los postulados, en su mayoría, no están llevando a cabo la reparación de sus víctimas desde el punto de vista económico, incumpliendo así con una de sus principales obligaciones porque no cuentan con los medios económicos en el caso de desmovilizados que hacían parte del nivel raso de la organización, o porque los bienes de esta habrían pasado a manos de otras personas antes del proceso de Justicia y Paz, o por su destrucción a lo largo del proceso de justicia transicional (Contraloría General de la República, Dirección de Estudios Sectoriales. Análisis de los Resultados y Costos de la Ley de Justicia y Paz, 2017d. Recuperado de http:// 
www.contraloria.gov.co/documents/20181/466201/Análisis+sobre+los+resultados+y+co $\underline{\text { stos+de+la+Ley+de+Justicia+y+Paz/dcce2907-f669-42gb8-8857- }}$

7e14750cc467? version $=1.0)$.

El XII Informe del Gobierno Nacional a las Comisiones Primeras del Congreso de la República, presentado en abril de 2018, dio a conocer cifras acerca de los avances de la política pública de atención, asistencia y reparación integral a las víctimas incluidos en el Plan Nacional de Desarrollo 2014.2018 "Todos por un Nuevo País":

Cuadro. 1. Cubrimiento de indemnizaciones en Justicia y Paz realizados por la Unidad para las Víctimas (2009-2018)

\begin{tabular}{|c|c|c|c|c|c|c|}
\hline \multirow[t]{2}{*}{ AÑO } & \multicolumn{2}{|c|}{$\begin{array}{l}\text { INDEMNIZACIONES } \\
\text { ADMINISTRATIVAS }\end{array}$} & \multicolumn{2}{|c|}{$\begin{array}{l}\text { INDEMNIZACIONES } \\
\text { JUSTICIA Y PAZ }\end{array}$} & \multicolumn{2}{|l|}{ TOTAL } \\
\hline & $\begin{array}{l}\text { No. } \\
\text { Indemnizaciones } \\
\text { otorgadas }\end{array}$ & Presupuesto & $\begin{array}{l}\text { No. } \\
\text { Personas }\end{array}$ & Presupuesto & $\begin{array}{l}\text { No. } \\
\text { Indemnizaciones } \\
\text { otorgadas }\end{array}$ & Presupuesto \\
\hline 2009 & 26.026 & $\$ 199.899,51$ & 0 & 0 & 26.027 & $\$ 199.899,51$ \\
\hline 2010 & 34.774 & $\$ 301,028,43$ & 0 & 0 & 34.774 & $\$ 301,028,43$ \\
\hline 2011 & 75.205 & $\$ 507.160,71$ & 0 & 0 & 75.205 & $\$ 507.160,71$ \\
\hline 2012 & 157.015 & $\$ 912.227,29$ & 954 & $\$ 24.146$ & 157.969 & $\$ 936.372,75$ \\
\hline 2013 & 96.851 & $\$ 583.233,76$ & 1.172 & $\$ 23.395,81$ & 98.023 & $\$ 606.629,57$ \\
\hline 2014 & 90.457 & $\$ 486.824,51$ & 1.260 & $\$ 19.795,02$ & 91.663 & $\$ 506.619,53$ \\
\hline 2015 & 103.740 & $\$ 521.439,63$ & 1.260 & $\$ 7.646,21$ & 105.000 & $\$ 529.085,85$ \\
\hline 2016 & 87.283 & $\$ 558.511,64$ & 593 & $\$ 13.568,89$ & 87.876 & $\$ 572.080,53$ \\
\hline 2017 & 110.833 & $\$ 754.262,46$ & 4.432 & $\$ 88.868,57$ & 115.265 & $\$ 843.131,04$ \\
\hline
\end{tabular}




\begin{tabular}{|l|r|r|r|r|r|r|}
\hline Total & $\mathbf{7 8 2 . 1 8 4}$ & $\mathbf{\$ 4 . 8 2 4 . 5 8 7 , 9 4}$ & $\mathbf{9 . 6 1 7}$ & $\mathbf{\$ 1 7 7 . 4 1 9 , 9 6}$ & $\mathbf{7 9 1 . 8 0 1}$ & $\mathbf{\$ 5 . 0 0 2 . 0 0 7 , 9 2}$ \\
\hline
\end{tabular}

Fuente: Unidad para las Víctimas. Control y Seguimiento - Corte diciembre de 2017. Cifras monetarias en millones de pesos (Gobierno de Colombia, 2018. XII Informe sobre los avances de la política pública de atención, asistencia y reparación integral a las víctimas del conflicto. Recuperado de https:// www.minsalud.gov.co/sites/rid/Lists/BibliotecaDigital/RIDE/DE/PS/xii-informe-gobierno-nacional-congreso-Ley-1448abril-2018.pdf).

El Gobierno nacional enfatizó en haber avanzado en la reparación integral de las víctimas, en su dimensión individual y colectiva, en sus cinco componentes: satisfacción, rehabilitación, indemnización, restitución y garantías de no repetición, no obstante, reconoce los retos presupuestales y operativos que demanda la indemnización de la totalidad de las víctimas en Colombia para lo cual le resulta necesaria la optimización de procesos de reconocimiento que contribuyan a la ampliación de cobertura y la coordinación de esfuerzos operativos y presupuestales (Gobierno de Colombia, 2018. XII Informe sobre los avances de la política pública de atención, asistencia y reparación integral a las víctimas del conflicto. Recuperado de https:// www.minsalud.gov.co/sites/rid/Lists/BibliotecaDigital/RIDE/DE/PS/xii-informe-gobiernonacional-congreso-Ley-1448-abril-2018.pdf).

Otro factor que problematiza el proceso de acuerdo al informe citado de la Sala de Justicia y Paz de Antioquia, es que con el fin de celebrar audiencias de incidente de reparación, las Salas de Justicia y Paz se han desplazado a municipios como Peque, Necoclí, Titiribí, Turbo, Tarazá y Caucasia en Antioquia; Valencia, Sahagún, Tierralta y Montería en Córdoba; Mariquita, Lérida, Guamo e Ibagué en el Tolima, Villavicencio en el Meta, entre otros, cuya logística también implica la conexión virtual con otras 
poblaciones donde residen desplazados y postulados que han sido extraditados, la ubicación de las víctimas para tal efecto y el acompañamiento sicosocial de entidades como el Bienestar Familiar y la Defensoría Pública (Tribunal Superior de Antioquia - Sala de Justicia y Paz, Oficio 07 Complemento al informe Análisis sobre resultados de la Ley de Justicia y Paz, 2017).

Como ya se había anunciado, cuando un postulado ha sido extraditado comparece a las audiencias a través de videoconferencias que lentifican el proceso pues debe contarse con el aval y logística del establecimiento penitenciario de los Estados Unidos que se logra por la intermediación del Ministerio de Relaciones Exteriores y el Consulado respectivo. Las audiencias no se practican con la frecuencia requerida, se presentan fallos en la red, deben solicitar su práctica con meses de antelación (Tribunal Superior de Antioquia - Sala de Justicia y Paz, Oficio 07 Complemento al informe Análisis sobre resultados de la Ley de Justicia y Paz, 2017).

Otro de los retos de la Ley 975 de 2005 se encuentra en la obligación de los postulados de informar la ubicación de cuerpos desaparecidos; la Fiscalía General de la Nación ha realizado 6.760 exhumaciones, ha identificado y entregado 3.996 restos. Sin embargo, las cifras no satisfacen las expectativas pues se esperaba que los actores del conflicto confesaran con exactitud la ubicación de todas las fosas y el paradero de los cuerpos desaparecidos; a saber la Fiscalía General de la Nación Delegada ante la Sala de Justicia y Paz del Tribunal Superior de Antioquia, con acompañamiento de la Cruz Roja Internacional y la Alcaldía de Medellín, ha intervenido en múltiples ocasiones y con 
resultados negativos el lugar llamado "La Escombrera", ubicado en la Comuna 13 de la ciudad de Medellín, caracterizado por encontrarse en la periferia del casco urbano donde se arrojan diariamente desechos de las construcciones, y donde alias "Berna" ha mencionado en múltiples ocasiones eran enterrados los cuerpos de las víctimas mortales del Bloque Cacique Nutibara de las AUC (Tribunal Superior de Antioquia - Sala de Justicia y Paz, Oficio 07 Complemento al informe Análisis sobre resultados de la Ley de Justicia y Paz, 2017).

Por otro lado, según los relatos de las víctimas y los victimarios, el paso del tiempo también ha afectado las labores de búsqueda de los cuerpos desaparecidos pues muchos de los miembros de los GAOML, que contaban con ese tipo de información, fallecieron; en otros casos los cuerpos también eran incinerados o lanzados a los ríos sin que quedara evidencia alguna (Tribunal Superior de Antioquia - Sala de Justicia y Paz, Oficio 07 Complemento al informe Análisis sobre resultados de la Ley de Justicia y Paz, 2017)..

Indudablemente la dimensión del conflicto armado rebasó la capacidad del Sistema de Justicia y Paz en número de hechos; por ejemplo, se identifican 313.475 hechos registrados, y hasta el $1^{\circ}$ de abril de 2017 se habían imputado 82.114, correspondientes a 211.013 víctimas de las 393.681 registradas, es decir, faltan por imputar 182.668 víctimas; requiriéndose más agilidad en los procedimientos. Las Salas de Justicia y Paz también presentan congestión, por ejemplo, la de Medellín adelanta procesos con más de 3.307 hechos, 6.333 delitos, 15.542 víctimas y expedientes con más de 450 carpetas 
relacionados con los Bloques Bananero y Calima de las AUC (Tribunal Superior de Antioquia - Sala de Justicia y Paz, Oficio 07 Complemento al informe Análisis sobre resultados de la Ley de Justicia y Paz, 2017).

A primera vista los resultados cuantitativos en materia de justicia de la Ley resultan ser de suyo precarios, y en relación con el costo del mismo, excesivos contrastados con las exiguas capacidades del Estado Colombiano. No obstante y desde el punto de vista cualitativo, no puede perderse de vista que se ha avanzado por parte de la Fiscalía General de la Nación en la investigación de los contextos y patrones de macro criminalidad, lo cual ha redundado indudablemente en el conocimiento de la historia, de la verdad, desde el punto de vista de los perpetradores y de las víctimas, ha permitido el conocimiento de lo acontecido, acercándonos a las razones y circunstancias del conflicto interno colombiano, su dinámica; pudiéndose entender como desde las postrimerías de mediados del siglo XIX y hasta este momento la violencia se ha "reciclado", cuando actores subversivos de la década de los 80 fueron luego reclutados por las organizaciones paramilitares denotando su carencia de ideales y vislumbrando el narcotráfico como la causa esencial de la guerra actual (Villamizar, 2017).

De todas formas, la experiencia internacional enseña que los procesos de reparación a víctimas son sumamente complejos e imperfectos, y como muestra se citan las víctimas de persecuciones nazis extranjeras que fueron perjudicadas o excluidas después de 1945, pues el gobierno de la República Federal consideró que las reclamaciones de víctimas extranjeras debían ser solucionadas a través del contexto de las reparaciones que fueron pospuestas indefinidamente debido a las enormes deudas externas de 
Alemania, hasta que por razones de política exterior, el gobierno federal se vio obligado a llegar a acuerdos de pagos con otros estados como Polonia, Rusia, Ucrania, Estonia, Ltuania y Yugoslavia (Romeike, 2016b, p.32).

Los procesos de Justicia y paz en Colombia han permitido visibilizar delitos atroces como la violencia de género considerado ahora como un patrón de macro criminalidad y no como hechos aislados o comunes, lo cual permite el entendimiento del conflicto, sus dinámicas y consecuencias. Aunque bajo la misma herramienta económica $-B-C-$, parezcan escasas las cifras en emisión de fallos, se rescata que 10 de las sentencias proferidas a nivel nacional condenaron a postulados por 21 masacres. La Sala de Justicia y Paz de Antioquia abordó masacres como El Aro, La Granja, Peque, Parques del Estadio, Campamento, San José de Apartadó, Hermanas Landeta, Juntas, Puerto Bélgica, Chorrillos, La Caucana, Barrio El Limonar 2 (Centro de Memoria Historica, 2012). Dichas masacres se han develado a nivel mundial, sus víctimas obtuvieron reconocimiento y se ha permitido su reparación; en las sentencias se han ordenado compulsas de copias en contra de agentes del Estado, incluido el entonces Gobernador de Antioquia y otrora presidente Álvaro Uribe Vélez por su presunta participación en las mismas, se ha ordenado indemnizar a víctimas directas e indirectas acreditadas por $\$ 149.782 .004 .789$, y se ha dispuesto la extinción de dominio de considerables bienes para reparación (Tribunal Superior de Antioquia - Sala de Justicia y Paz, Oficio 07 Complemento al informe Análisis sobre resultados de la Ley de Justicia y Paz, 2017). 
En este punto la relación Costo - Beneficio no es cuantificable por la naturaleza de los logros alcanzados; en el desarrollo de los procesos el perdón que ofrecen los perpetradores y el perdón que otorgan las víctimas, implica su renuncia a permanecer como actores en un círculo progresivo de violencia, su dignificación, su capacidad de resiliencia, valentía, en algunos casos la reivindicación de su buen nombre al haber sido tachados de miembros de grupos subversivos, su reconocimiento y que a nivel nacional e internacional sean divulgadas las barbaries cometidas, sus actores y la participación que en ellas tuvieron miembros del Estado, redundando todo ello en la no repetición de ese tipo de hechos (Forer, 2018). Múltiples familias han recibido los despojos de sus familiares cesando así la angustia que conlleva el desaparecimiento de un ser querido (Tribunal Superior de Antioquia - Sala de Justicia y Paz, Oficio 07 Complemento al informe Análisis sobre resultados de la Ley de Justicia y Paz, 2017).

Según lo reportado por el Sistema de Justicia Transicional en 2017, se tiene también que el número de sentencias de Justicia y Paz ha aumentado a 50, así como el número de víctimas reconocidas y siguen investigaciones en desarrollo como las del Bloque Elmer Cárdenas en el Tribunal de Antioquia, los incidentes de reparación de Bloque Mineros, Cacique Nutibara y Héroes de Granada de las AUC; cifras importantes que aunque no satisfagan las expectativas van en aumento (Tribunal Superior de Antioquia - Sala de Justicia y Paz, Oficio 07 Complemento al informe Análisis sobre resultados de la Ley de Justicia y Paz, 2017). 


\subsection{Análisis de las cuestionadas cifras del sistema de justicia y paz}

De acuerdo a la herramienta cuantitativa Costo - Beneficio la ejecución de las medidas insertas en la Ley 975 de 2005, hasta nuestros días, ha sido más onerosa que los beneficios derivados de la mismas; sus resultados numéricos no satisfacen las expectativas de acuerdo al altísimo presupuesto erogado en su ejecución, colocando así en tela de juicio el cumplimiento de los fines de Verdad, Justicia, Reparación y No Repetición de la norma, debido a las escasas sentencias emitidas, el número de postulados efectivamente juzgados y el número de víctimas indemnizadas, entre otros aspectos ya analizados (Contraloría General de la República, Dirección de Estudios Sectoriales. Análisis de los Resultados y Costos de la Ley de Justicia y Paz, 2017d. Recuperado de http:// www.contraloria.gov.co/documents/20181/466201/Análisis+sobre+los+resultados+y+co stos+de+la+Ley+de+Justicia+y+Paz/dcce2907-f669-42gb8-8857-

7e14750cc467?version $=1.0$ ).

No obstante, aunque las cifras disten de las expectativas deseadas, el espacio que se dedique a la reconciliación, al perdón, a la verdad, a la reparación de las víctimas y de la sociedad, a los compromisos serios de no repetición por parte de los perpetradores y del Estado, implica una profunda transformación social incuantificable que fortalece la cohesión de la nación colombiana y del Estado social de derecho sobre el que se funda. 
En suma, que este ejercicio de justicia transicional sirva de experiencia para la implementación de otros procesos como la Justicia Especial para la Paz con las FARC;

que los errores y las bondades del pasado redunden en la construcción de la paz, que se propicien más espacios de reconciliación que de guerra y que se sigan reconociendo y dignificando aquellas víctimas de atrocidades que a gritos se sepultaron ante el silencio de una sociedad que incólume acalló las voces de auxilio

\section{CAPÍTULO IV}

\section{JUSTICIA TRANSICIONAL Y COMPETENCIA RESIDUAL DE LA CORTE PENAL INTERNACIONAL EN COLOMBIA}

Los estándares internacionales e internos en materia de reparación a las víctimas del conflicto armado interno parecen ser hoy lejanos tanto para las víctimas de los grupos paramilitares cómo para los que fueron víctimas de otras agrupaciones armadas ilegales. El derecho a la reparación integral y el reconocimiento como víctima son hechos consustanciales y en Colombia han tenido un camino proceloso y lleno de interpretaciones de carácter jurídico y político disimiles incluso en ocasiones contrapuestas. Las víctimas de graves violaciones de los derechos humanos y del 
derecho internacional humanitario como consecuencia de más de cinco décadas continúas de duración del Conflicto Armado Interno, ahora cuentan con toda una serie de instrumentos de orden jurídico que les permiten acudir a la reparación integral de carácter indemnizatorio ante el Estado y sus autoridades judiciales y administrativas. Sin embargo, la práctica y los informes contratados por el gobierno nacional, muestran como este derecho y los procesos de reparación hoy son todavía poco efectivos (Garay Salamanca, 2013c).

Así las cosas, en las escasas sentencias proferidas en el trámite de la ley 975 de 2005, a pesar de considerar en algunas ocasiones que responden a crímenes de lesa humanidad, no identifican ni someramente a cuáles crímenes se refiere y los elementos de tales, bajo la perspectiva del Estatuto de Roma; tal y como lo exige la misma Sala Penal de la Corte Suprema de Justicia y la Corte Penal Internacional para los efectos. De la misma manera, la referencia a la existencia de crímenes de lesa humanidad exigiría que en las sentencias se reflejaran los patrones de comisión, tanto a nivel local de cada bloque, teniendo en cuenta las víctimas, el comportamiento de las autoridades locales, contexto de agresiones; como a nivel nacional.

Como se advierte, son escasas las providencias en que dichos elementos son tomados en cuenta. Por último, cabe destacar la cuestión de la tipificación de los homicidios en tanto en la mayoría de las ocasiones se legalizan los cargos por homicidio en persona protegida, lo que en la perspectiva de crímenes internacionales equivale a calificarles como crímenes de guerra. Si bien un delito puede calificarse al mismo tiempo como 
crimen de guerra y como crímenes de lesa humanidad, pero para esto último se requiere un análisis sobre sistematicidad y generalización, ejercicio que están omitiendo los jueces, contando con elementos para hacerlo.

Así pues, examinadas las cifras de aplicación del Sistema de Ley 975 de 2005, así como un profundo análisis de orden cualitativo, este capítulo determinará la baja efectividad de las herramientas dispuestas en dicha ley en favor de las víctimas y los principios de Reparación y No Impunidad; bajo este panorama debe determinarse, en consecuencia, si se cumplen los requisitos para la activación de competencia complementaria de la Corte Penal Internacional en el caso colombiano y con ocasión del proceso de justicia transicional en mención.

\subsection{La Ley de Justicia y Paz y la violación del estándar de reparación}

Resulta claro cómo el proceso diseñado por la Ley 975, respecto de la consecución de la verdad depende de la conjunción de dos factores. El primero, de las confesiones libres que realicen los postulados y en el segundo, de lo que haya logrado conocer la Fiscalía en su labor de confrontación de dichas versiones con los relatos de las víctimas y otros elementos probatorios (Wolffughel, 2011b). Esta situación contribuye de manera sustantiva a la consolidación de los altos niveles de impunidad y la insatisfacción de las víctimas que asistían a las versiones de los indiciados. En tal virtud y producto de las 
declaraciones de los postulados en la Ley de Justicia y Paz, como ya se analizó de cifras oficiales reportadas, para 2017, como resultado de la confesión de los miembros de GAOML en hechos delictivos, se habrían imputado por la Fiscalía 82.114 hechos que implican 211.013 víctimas, restando 231.361 hechos faltantes de imputación.

Además, según las versiones libres rendidas por los desmovilizados, se ha logrado la identificación y ubicación de 3.557 menores de edad víctimas del reclutamiento y la documentación de 34.467 casos de desaparición forzada, faltando así la culminación de los procesos por la mayoría de los hechos que requieren la aplicación del principio de No Impunidad, como se trató en el capítulo anterior.

En el mismo sentido, la ley establece la drástica reducción de la pena alternativa frente a la pena ordinaria, para aquellos miembros de los grupos de autodefensas, lo que conllevó que la pena alternativa aplicada los miembros de estas organizaciones llegara al máximo de los ocho años; no obstante la proporción entre reclusión y gravedad de la conducta penal cometida, sencillamente carece de un sentido de proporcionalidad respecto de las obligaciones internacionales de los estados miembros de la comunidad internacional (Ambos, 2010b).

Lo señalado antes, revela que la regulación de los aspectos sustantivos atinentes a la aplicación del Principio de Complementariedad en el Estatuto de Roma respecto de la Ley 975 de 2005 gira en torno del sostenimiento del delicado equilibrio que se debe encontrar entre la prerrogativa otorgada a las jurisdicciones nacionales y la facultad de 
supervisión que sobre éstas se reconoce a la Corte Penal Internacional. La activación de la competencia eventual se da entonces según la combinación de tres factores. El primero que el Estado no tenga la intención de investigar y juzgar los graves crímenes contra la humanidad, en segundo lugar, que el Estado no tenga capacidad institucional de realizar dichas obligaciones, y el tercero, que el Estado aun teniendo la voluntad de investigar, carezca de los medios judiciales suficientes para hacerlo, y así lo ha citado Wolffughel (2011c, p.38):

"De esta manera, se optó porque los estados tuvieran esa primera oportunidad de investigar y juzgar los crímenes internacionales. Se trata de una "primacía formal" - como algunos llaman de buena fe (Jensen, 2005) - de las jurisdicciones nacionales, cuyo cometido es buscar que en el contexto nacional se adelanten las investigaciones y enjuiciamientos de los crímenes más graves. Así mismo, se le asigna a la Corte Penal Internacional una "primacía material" en aquellos asuntos en los que las jurisdicciones nacionales son incapaces de actuar o cuando ellas demuestran la falta de disposición para investigar y enjuiciar a los presuntos responsables de los crímenes nucleares."

Esto es que la jurisdicción de la CPI solo aparece y se ejerce solo cuando se presenta la inacción o la carencia de disposición o la ausencia de capacidad de las jurisdicciones nacionales. Si estos supuestos se presentan en Colombia entonces sería plausible ver a la CPI complementando al Estado Colombiano en el juzgamiento de estas conductas. La magnitud de las víctimas, crímenes y afectaciones, en contraste con las 47 sentencias producidas en los procedimientos de la Ley 975 de 2005 en lo relativo a los crímenes de lesa humanidad cometidos por el paramilitarismo en complicidad y colaboración con el Estado, nos lleva a una primera conclusión de cumplimiento de requisito de admisibilidad 
para apertura de investigación por la Fiscalía de la Corte Penal Internacional, en los crímenes imputables a los mismos que se hayan cometido a partir del $1^{\circ}$ de noviembre de 2002.

En este punto la Justicia Transicional encuentra un dilema en el escenario internacional; ¿se deben castigar a los responsables o pasar la página? La primera de las opciones encuentra fundamento en el desarrollo y construcción de un orden moral justo, en la obligación de reivindicación con las víctimas y la consolidación del estado de derecho; por el contrario, "el pasar la página" implica otorgar un valor más profundo a la reconciliación nacional que al castigo, dejando de un lado el "desquite sistemático" para que haya una paz verdadera y duradera (Huyse, 2013, p.8)

\subsection{Relación entre la Ley de Justicia y Paz y la Jurisdicción Especial Para la Paz.}

La JEP o Jurisdicción Especial para la Paz, es la forma en la que se materializó la negociación entre el Estado Colombiano y el grupo armado al margen de la ley FARC. Esta jurisdicción de carácter temporal y específico opera por medio del juzgamiento ante el Tribunal Especial para la Paz, aquellas conductas de quienes que participaron en el marco del conflicto armado. Tras la firma del "acuerdo final para la terminación del conflicto y la construcción de una paz estable y duradera" y respecto a lo acordado en el punto 3 denominado "fin del conflicto"; La Justicia Especial Para La Paz (JEP) ejercerá funciones del sistema integral de verdad, justicia, reparación y no repetición; es la manifestación del Estado Colombiano con base en el DIH y el DIDH para esclarecer, 
investigar, y juzgar los actos violentos cometidos durante el conflicto interno armado (Oficina del Alto comisionado para la paz, 2018a. Recuperado de http://www.altocomisionadoparalapaz.gov.co/Documents/informes-especiales/abc-delproceso-de-paz/abc-jurisdiccion-especial-paz.html). Ese tribunal es el encargado de contribuir al desarrollo de la paz y lo más importante contribuir a la reparación de las víctimas, entre otros (Barbosa, 2017).

Los acuerdos entre el Gobierno y las agrupaciones armadas al margen de la ley, establecieron un sistema integral de verdad, justicia, reparación y no repetición, el cual tiene varios componentes, en primer término, una justicia para la verdad, una unidad de búsqueda de personas desaparecidas, algunos mecanismos específicos de reparación. Este se divide en: una sección del esclarecimiento de la verdad, de amnistías e indultos, de definición de situaciones jurídicas y por último contará con un Tribunal para la Paz, que está compuesto por 51 magistrados y cinco secciones que funcionaran de manera interrelacionada como un sistema jurídico propio, las cuales a grandes rasgos van a evaluar los grados de responsabilidad de los integrantes de esas organizaciones en la comisión de los hechos punibles en el marco del conflicto armado de las personas que se acojan a este mecanismo (Oficina del Alto comisionado para la paz, 2018b. Recuperado de: http://www.altocomisionadoparalapaz.gov.co/Documents/informesespeciales/abc-del-proceso-de-paz/abc-jurisdiccion-especial-paz.html).

La JEP tiene como fundamento la aceptación por parte del Estado Colombiano una política de reparación a las víctimas y el esclarecimiento de los hechos ocurridos en el 
marco del conflicto armado, en especial aquellos hechos que tienen que ver con la confrontación bélica desarrollada con el grupo insurgente de las FARC. Por esta razón, para acceder a la JEP el requisito primordial es la confesión de la verdad por parte de los perpetradores junto con la investigación judicial a cargo del Estado, lo que a todas luces, esta contrapuesto con los estándares mínimos de justicia requeridos para resarcir a las víctimas de actos ilícitos de extrema gravedad jurídica a la luz de las normas internacionales ${ }^{5}$. Existen dos tipos de procedimientos en la JEP, en primer lugar, en los casos de reconocimientos de verdad y responsabilidad, y, en segundo lugar, en los casos de no reconocimiento de responsabilidad. Frente al primer tipo de procedimiento, se restringirá la libertad entre 5 y 8 años, y también se le reconocerá, luego de la contribución que haga al esclarecimiento de la verdad, la imposición de penas de trabajo, tales como: la construcción de viviendas de lugares afectados por el conflicto o labores de desminado humanitario, entre otros (Oficina del Alto comisionado para la paz, 2018c. Recuperado de: http://www.altocomisionadoparalapaz.gov.co/Documents/informesespeciales/abc-del-proceso-de-paz/abc-jurisdiccion-especial-paz.html).

En segundo caso, aquellos individuos que no contribuyan con el esclarecimiento de los hechos y a los que se les compruebe la culpa o responsabilidad en el hecho punible imputado, no tendrán derecho a ningún trato especial ni a ninguna prórroga y se les aplicarán condenas privativas de la libertad de 20 años. Ello por medio de investigaciones que el Estado seguirá realizando, cuando, tales individuos sean retirados del Tribunal

\footnotetext{
${ }^{5}$ En días pasados el director para las américas de la reputada ONG norteamericana Human Rights Wacht, José Miguel Vivanco le dirigió una carta al presidente colombiano en la que le expresaba esta y otras serias inquietudes respecto de la aprobación de la ley estatutaria de la JEP. La carta completa puede conseguirse en el siguiente enlace. http://caracol.com.co/radio/2017/10/09/nacional/1507561328 323445.html
} 
Especial de Paz. Este tipo de medidas tienen como fundamento el incentivar a los partícipes del conflicto armado a que se acojan a la JEP y contribuyan en gran medida con el esclarecimiento de la verdad de los hechos (Oficina del Alto comisionado para la paz, 2018d. Recuperado de: http://www.altocomisionadoparalapaz.gov.co/Documents/informes-especiales/abc-delproceso-de-paz/abc-jurisdiccion-especial-paz.html). Razón que de manera clara limita en grado superlativo la acción punitiva del Estado y envía un equivocado mensaje a la sociedad, puesto que tales medidas pueden interpretarse como un incentivo para delinquir y conservar incólumes los más altos niveles de impunidad en la acción estatal.

La JEP, tiene en su estructura funcional, una sala que se denomina "Sala de Reconocimiento de Verdad y Responsabilidad y de Determinación de los Hechos y Conductas (SRVR)" y es donde se recibirán todos los casos en los cuales se asuma responsabilidad en los hechos por parte de la persona desde un principio; está también la sala de amnistía e indulto la cual decide, dependiendo del caso, a quien se le otorga la amnistía y el indulto - vale la pena aclarar que no todos los actos cometidos en el marco del conflicto son amnistiables -. Para quienes no entren en ninguna de las dos salas, existirá una sala denominada "Sala de Definición de Situaciones Jurídicas"; frente a los casos donde no se haya reconocido ningún grado de responsabilidad la "Unidad De Investigación y Acusación" será quien investigue y acuse ante el tribunal según sea el caso; y por último está el Tribunal para la Paz el cual será "el órgano de cierre de la JEP" (Oficina del Alto comisionado para la paz, 2018e. Recuperado de: 
http://www.altocomisionadoparalapaz.gov.co/Documents/informes-especiales/abc-delproceso-de-paz/abc-jurisdiccion-especial-paz.html).

La JEP es concebida como la estructura central del acuerdo establecido entre el gobierno de Juan Manuel Santos y los miembros de las FARC. Negociar la desmovilización con un grupo que ha estado vulnerando de manera continua la ley por el transcurso de más de cinco décadas, es insertar a un número de personas a las dinámicas del sistema político, por medio de una ley especial, en la que serán amnistiados (dependiendo sus delitos) y reinsertados a la sociedad, incluso cuando las conductas punibles resulten ser de extrema gravedad, como las graves infracciones al $\mathrm{DIH}$, cometidas por entre otros los miembros vivos del denominado Secretariado de la Organización. Esto plantea de un lado, que el Estado vea seriamente restringido su accionar punitivo, es decir su capacidad de imponer penas severas, o cuando menos equivalentes, con la gravedad de las conductas antijurídicas cometidas por los miembros de los grupos armados desmovilizados, en este caso Guerrilla y Paramilitares.

En segundo lugar y esto resulta mucho más grave, tanto la Ley de Justicia y Paz, como la JEP o Justicia Especial Para la Paz, pueden activar residualmente la competencia subsidiaria y complementaria de la Corte Penal Internacional, o llevar al Estado Colombiano ante los estrados de responsabilidad de la CIDH. Porque como se ha visto se presentan varios supuestos que alteran las disposiciones de la normatividad internacional en relación con las obligaciones del Estado de salvaguarda de los derechos de las víctimas de la confrontación. En primer lugar, no hay proporcionalidad entre la 
gravedad de las conductas punibles y la pena asignada a los responsables de la comisión de estos delitos. En segundo lugar, porque la CPI tiene por vía jurisprudencial mecanismos de evaluación que le permiten determinar si, alguno de los supuestos de la activación de su competencia, se dan en el caso colombiano o no.

En cualquiera de los dos supuestos, la capacidad el Estado de imponer las penas y las sanciones jurídicas, es decir la facultad lus Pudiendi atribuida al Estado se ve seriamente amenazada por la emergencia de la Justicia Transicional. Esto, contrario a asegurar la paz, puede generar nuevas situaciones de violencia, por cuanto, el incentivo que se otorga a la criminalidad es por ejemplo participar en política, ir al Congreso de la República y gozar de bienes jurídicos como la libertad, o el libre tránsito, bienes jurídicos que el Estado niega a otros individuos que han violado la normas, pero no con la gravedad y sistematicidad en que lo han hecho los líderes de la organización FARC.

\subsubsection{Ruta de las víctimas en la JEP}

"De conformidad con el propio Acuerdo de Paz suscrito en 2016 entre el Gobierno nacional y las Fuerzas Armadas Revolucionarias de Colombia (FARC-EP), son objetivos de la JEP, entre otros, satisfacer el derecho de las víctimas a la justicia, ofrecer verdad a la sociedad colombiana, contribuir a la reparación de las víctimas y contribuir a luchar contra la impunidad. Dentro de sus principios rectores se destacan en dicho marco:

(1) La centralidad de las víctimas y de sus derechos a la verdad, la justicia, la reparación y la no repetición (VJR); (2) la condicionalidad del tratamiento especial previsto en ella a que se contribuya a la satisfacción de dichos derechos; (3) la integralidad en el sentido de su coherencia con los demás órganos del Sistema Integral de VJR lo que 
se debe traducir en garantizar una contribución efectiva y articulada a las medidas de satisfacción de los derechos de las víctimas; (4) el debido proceso; (5) el enfoque diferencial y de género, en el sentido que la JEP deberá tener en cuenta las distintas consecuencias e impactos desproporcionales de las violaciones en relación con sujetos de especial protección y sus órganos deberán conformarse con criterios de equidad de género y respeto a la diversidad étnica, religiosa y cultural" ((1) La centralidad de las víctimas y de sus derechos a la verdad, la justicia, la reparación y la no repetición (VJR); (2) la condicionalidad del tratamiento especial previsto en ella a que se contribuya a la satisfacción de dichos derechos; (3) la integralidad en el sentido de su coherencia con los demás órganos del Sistema Integral de VJR lo que se debe traducir en garantizar una contribución efectiva y articulada a las medidas de satisfacción de los derechos de las víctimas; (4) el debido proceso; (5) el enfoque diferencial y de género, en el sentido que la JEP deberá tener en cuenta las distintas consecuencias e impactos desproporcionales de las violaciones en relación con sujetos de especial protección y sus órganos deberán conformarse con criterios de equidad de género y respeto a la diversidad étnica, religiosa y cultural" (CONSULTORIA PARA LOS DERECHOS HUMANOS Y EL DESPLAZAMIENTO CODHES, AGENCIA DE LOS ESTADOS UNIDOS PARA EL DESARROLLO INTERNACIONAL, USAID, 2017)

En el Sistema Integral de Verdad, Justicia, Reparación y No repetición, el Estado se ha comprometido a garantizar la reparación de las víctimas de infracciones a los Derechos Humanos y al Derecho Internacional Humanitario con ocasión del conflicto armado; su satisfacción, de manera adecuada, integral, diferenciada, efectiva, igualitaria y equitativa, constituye uno de los ejes principales para la reconciliación y la construcción de una paz estable y duradera en el territorio nacional

"El conflicto armado, que tiene múltiples causas, ha ocasionado un sufrimiento y un daño a la población sin igual en nuestra historia. Son millones los colombianos y colombianas víctimas de desplazamiento forzado, cientos de miles los muertos, decenas de miles los desaparecidos de toda índole y un amplio número de familias, colectivos y poblaciones afectadas a lo largo y ancho del territorio, incluyendo comunidades campesinas, indígenas, afrocolombianas, negras, 
palenqueras, raizales, y Rom, personas en razón de sus creencias religiosas, partidos políticos, movimientos sociales y sindicales, población LGBTI y gremios económicos, entre otros. Sin olvidar otras formas menos visibles pero no menos dolorosas de victimización, como la violencia sexual, las afectaciones psicológicas, o la simple convivencia con el miedo." (ACUERDO FINAL PARA LA TERMINACIÓN DEL CONFLICTO Y CONSTRUCCIÓN DE UNA PAZ ESTABLE Y DURADERA, 2016, p.126)

Acto Legislativo 01 del 4 de abril de 2017.Artículo transitorio 18. Reparación Integral en el Sistema Integral de Verdad, Justicia, Reparación y No repetición. En el marco del Sistema Integral de Verdad, Justicia, Reparación y No Repetición, el Estado garantizará el derecho a la reparación a las víctimas de graves violaciones a los derechos humanos e infracciones al Derecho Internacional Humanitario que hayan sufrido daños, individual o colectivamente con ocasión del conflicto armado. La reparación será garantizada por el Estado de manera integral, adecuada, diferenciada y efectiva, priorizando la distribución de las medidas de reparación entre las víctimas teniendo en cuenta el universo de víctimas del conflicto armado y buscando la igualdad en el acceso y la equidad en la distribución de los recursos disponibles, y dando preferencia en la atención a los sujetos de especial protección constitucional.

Para el reconocimiento de sus derechos, las víctimas pueden participar en los juicios orales, acceder a los expedientes, interponer recursos contra las decisiones y acceder a medidas de protección; se tienen como víctimas sujetos individuales o colectivos que sufrieron daños o afectaciones directas por graves violaciones a los Derechos Humanos y al Derecho Internacional Humanitario, incluyéndose comunidades indígenas, negras (afrocolombianas, raizales y palenqueras), y Rom, grupos y organizaciones sociales y políticas.

Acto Legislativo 01 del 4 de abril de 2017. Artículo 12 transitorio, parágrafo. Las normas que regirán la Jurisdicción Especial de Paz, incluirán garantías 
procesales, sustanciales, probatorias y de acceso, encaminadas a que las víctimas puedan satisfacer sus derechos a la verdad, justicia y reparación en el marco de la JEP con medidas diferenciales y especiales para quienes se consideren sujetos de especial protección constitucional. Igualmente, deberán garantizar los principios de tratamiento penal especial condicionado a la garantía de los derechos de las víctimas, centralidad de las víctimas, integralidad, debido proceso no regresividad en el reconocimiento de derechos y enfoque diferencial $y$ de género.

Las víctimas podrán participar a través de abogado de confianza, del apoderado que les brinde la organización de víctimas o de la Defensoría Pública, en todo el curso del proceso, desde el reconocimiento de la verdad hasta en los juicios orales. Su participación tiene lugar con el informe que se presenta ante la Sala de Reconocimiento, en el cual se narran los hechos victimizantes ocurridos en el marco del conflicto armado de manera detallada, presentando una prueba sumaria de su condición e identificando a los agresores, si es posible.

Seguidamente la Sala emitirá una decisión de acreditación o no de la víctima, frente a la cual proceden recursos en caso de ser negativa. Desde el 15 de marzo de 2018 la JEP recibe tales informes, plazo que se prolongará hasta el 15 de marzo de 2020.

Desde la promulgación de la Ley 1448 del 2011, en nuestro país se creó un sistema para proteger, asistir, atender y reparar a las víctimas del conflicto armado; norma guiada por un espíritu de acompañamiento estatal en materia de educación, salud, vivienda, empleo, capacitación, además de las acciones de reparación, indemnización, restitución de bienes y de no repetición (Ministerio del Interior, Ley de Víctimas y Restitución de Tierras y Decretos Reglamentarios, 2012. Recuperado de http: //www.centrodememoriahistórica,gov.co/micrositios/caminosparalamemoria/decargable s/ley1448.pdf/). 
A partir de la creación de este sistema de reparación, el Estado de manera histórica reconoció su responsabilidad con las víctimas del conflicto armado interno; la Unidad Especial para la Reparación de Víctimas informa para enero de 2018 que las indemnizaciones han incluido 800.000 víctimas de la guerra y atención en múltiples aspectos a fin de promover la paz y la reconciliación nacional (Unidad para la Atención y Reparación Integral a las Víctimas, Informe de Gestión, 2017. Recuperado de http: //www.unidadvictimas.gov.co/sites/default/files/documentosbiblioteca/informede gestión 2017/).

Según el Informe de Gestión 2017 de la Unidad de Víctimas, se tramitaron 4.329.438 solicitudes de víctimas y se atendieron 3.179.662, cifra histórica de solicitudes de atención; en virtud de las sentencias de Justicia y Paz desde el año 2012 se han reparado 9.638 víctimas por valor de $\$ 177.710 .073 .934,47$ (UARIV, 2017), ahora, la coyuntura histórica exige al Sistema la optimización de recursos y procedimientos en la dinámica de atención a las víctimas para brindar la satisfacción real de sus derechos.

Por otro lado, durante el año 2017, la UARIV recibió un total de 114.371 acciones de tutela instauradas por víctimas que por esta extraordinaria vía reclaman atención y reparación integral (UARIV, 2017), cifra que permite establecer un elevado nivel de insatisfacción en la prestación del servicio del Sistema de Atención a Víctimas y reclama la reorganización de los procesos operativos de la Unidad para atender la demanda que ascendería con la implementación de la JEP a partir de marzo de 2018.

Las críticas mediáticas llueven además para el sistema de reparación, reprochándose que aunque el Estado ha invertido 81 billones de pesos en planes para la atención de víctimas de conflicto armado en los últimos siete años, no se han cumplido las metas trazadas con la expedición de la Ley 1481 de 2011; queda pendiente la restitución de más de 700.000 hectáreas de tierra del millón que fueron afectadas por causa del conflicto, falta por atender cerca de 3.000 .000 de víctimas en el Programa de Atención Psicosocial pues solo se ha atendido un $20 \%$ de la población, falta el $90 \%$ de las víctimas en recibir las indemnizaciones a pesar que el Estado ha pagado alrededor de 5 billones 
de pesos, reclamándose la prolongación de la ley de víctimas que expira en el 2021 (Redacción Colombia2020, 7 de agosto de 2018, Presidente Duque, estas son las 10 deudas del estado con las víctimas, El Espectador. Recuperado de http:// colombia2020.elespectador.com/politica/presidente-duque-estas-son-las-10-deudasdel-estado-con-las-victimas).

En suma, el Sistema Nacional de Atención y Reparación Integral a las Víctimas, debe aumentar esfuerzos para lograr la reparación integral de las víctimas del conflicto armado que resulten reconocidas por la JEP; implementar estrategias de cobertura, ejecutar proyectos y programas de atención asistencia y reparación a poblaciones que podrán multiplicarse en la medida que se develan infracciones a Derechos Humanos y al Derecho Internacional Humanitario en el curso de tales procesos.

\subsection{Elementos del estándar en el Sistema Interamericano de Derechos Humanos}

Igualmente y derivado de la jurisprudencia de la Corte Interamericana de Derechos Humanos, encontramos la obligación del Estado de combatir y evitar la impunidad, puesto que se considera que "el Estado tiene el deber de investigar las violaciones de los derechos humanos y procesar a los responsables y evitar la impunidad", de forma tal que es en cabeza de este que reside dicha obligación, puesto que la naturaleza de las funciones del Estado es la de no permitir que sus asociados sufran de dichas violaciones en forma reiterada, gracias a que la impunidad y la inacción en la persecución de los responsables genera situaciones de re victimización. Según la Corte Interamericana de Derechos Humanos el acceso a un recurso de reparación de las víctimas debe tener la característica de ser adecuado y disponible, así como ser rápida y eficaz, no obstante, la jurisdicción en que este se halle, por ello la misma premisa debe ser aplicada a las 
jurisdicciones constitucional, penal, civil, administrativa o disciplinaria (Nash Rojas, 2004).

Para que el Estado garantice de manera efectiva estos derechos, la jurisprudencia internacional ha dispuesto que los Estados deben brindarle a las victimas el acceso a recursos judiciales efectivos e impartir justicia, es decir que los recursos judiciales empleados en tal propósito sean efectivamente medios que de forma expedita consigan el propósito para el cual fueron incoados. En esta materia, la Corte Interamericana y la Corte Constitucional han establecido que los recursos, para ser efectivos, deben ser adecuados, eficaces y estar disponibles. Un recurso judicial es en esta perspectiva adecuado, cuando es idóneo para proteger la violación infringida. Es eficaz cuando este es capaz de producir los efectos jurídicos esperados, es decir, aquellos para los cuales fue concebido; y está disponible cuando es accesible a las víctimas, así de manera contraria el recurso no es efectivo, por lo tanto, cuando no es útil para producir efectos concretos.

\subsection{Lecciones históricas para la discusión acerca del futuro de las víctimas del conflicto armado en Colombia en el escenario de pos acuerdo - una perspectiva antípoda acerca del perdón}

Hoy, no cabe duda, que en la conciencia colectiva de la humanidad contemporánea el execrable mosaico de crímenes cometidos por el nacionalsocialismo afincado en el 
influjo abrasador de la ideología y la política nazis, durante doce oscuros años en Europa, son los mayores fardos que arrastra la memoria común de la especie humana en el siglo XX (Hobsbawm, 1998). Los ensayos de los escritores Jean Amery (2004) y Primo Levi (2005) junto con la discusión filosófica en torno del perdón, nos abren la ventana al atestiguamiento de una cruda perspectiva personal de las experiencias y las proyecciones del dolor y la victimización a la que fueron sometidos los autores, ello, en razón de detentar la condición de pertenecer a la comunidad judía, y estar a su vez insertos por obra de las peripecias del destino y el devenir histórico en medio del ascenso y posterior derrumbamiento de la dictadura fascista en Alemania. Sus experiencias personales parten de su confinamiento forzoso en los campos de concentración en Polonia y Bélgica ocupadas por las hordas fascistas, parten a su vez, del sometimiento a las más deleznables condiciones de tortura, degradación, temor, surgen también, al presenciar impotentes la muerte masiva de sus semejantes y de la desesperación sucedánea ante el destino inminente y adverso que les aguardaba tras los muros, las barracas, las cámaras de gas, las fosas comunes y los hornos crematorios de Auschwitz, Treblinka, Breendonck y Bergen Belsen.

Estas terribles experiencias vividas son la dolorosa base sobre la cual los autores expresan con furor su vehemente rechazo a la generalización que suele hacerse de su condición como víctimas, en la cual se les atribuye casi que, de forma obligatoria, que el perdón y la reconciliación, son las salidas válidas y expeditas para conseguir la reivindicación de la memoria colectiva y del dolor del pueblo judío, sometido al régimen hitleriano en Europa durante la segunda guerra mundial. Por ello bien vale la pena 
preguntarse: ¿Están las victimas de graves violaciones a su integridad y humanidad, obligadas indefectiblemente a perdonar a sus victimarios como condición previa para la reconciliación? Levi y Amery, están de acuerdo en que no. El pueblo alemán consintió o cuando menos fue cómplice directo o silencioso de los crímenes que detrás de las alambradas y las torretas de vigilancia se cometían contra seis millones de judíos indefensos en las fábricas de la muerte y la dignidad colectiva en que se convertirían los campos de concentración del Régimen Hitleriano (Levi, 2005).

Tanto Levi como Amery nos advierten de la culpabilidad colectiva del pueblo Alemán, puesto que a pesar de los rechazos aislados que valerosos ciudadanos alemanes desarrollaron en contra del régimen fascista, el resto de la población germana, no acudió en defensa de los millares de seres humanos que morían a diario, incinerados, ahogados, por hambre o sencillamente ametrallados por los esbirros del ejército alemán, quien estaba enteramente insensibilizado por el enrevesado ideario nacionalsocialista. Ideario que se había tomado también la mentalidad general del pueblo alemán, y que no sería enteramente extirpado hasta la liberación de los aliados en 1945. Para Levi, fue el propio ejército alemán y sus cuerpos de exterminio quienes corrompieron los cimientos de la integridad de los judíos en la cruel cotidianidad del diario devenir en los campos de concentración. Puesto que ellos establecían jerarquías y otorgaban privilegios a grupos colaboracionistas de prisioneros con tal de detentar un férreo control interno en los campos, lo cual victimizaba y degradaba aún más la condición de quienes fueron sometidos a semejante ignominia. El propósito último de la tortura contra los cautivos era la reducción completa del sentido de humanidad de los hombres, en su manifestación 
interior y exterior en razón de ser judíos, comunistas, gitanos etc., esto también extinguía la humanidad de los guardias y los verdugos nazis y sus colaboradores, puesto que perdían por esta vía cualquier noción de horror y de sensibilidad en la comisión de sus crímenes, era en síntesis una situación extrema e indescriptible de negación de la más elemental condición humana, de los valores más básicos del hombre racional (Amery, 2004).

Jean Amery, por su parte revindica el papel central del resentimiento en contra de los victimarios fascistas como una herramienta fundamental para no borrar de la memoria colectiva humana el hecho indeleble de la catástrofe judía, pero sobre todo para que el pueblo alemán asuma su responsabilidad histórica por permitir, por acción u omisión, la ocurrencia de este episodio estremecedor y oscuro. Seis millones de seres humanos perecieron de las más indecibles formas ante la anuencia y la omisión dolosa e indiferente de la mayor parte de la población alemana o por la sevicia de la ideología fascista hecha paroxismo asesino en las manos de las tropas nazis. Los golpes, las torturas la muerte son un rasgo estremecedor no solo del dolor interno físico y moral, sino sobre todo un rasgo de la perdida de la fe en la humanidad, en palabras de Amery "pérdida de confianza en el mundo".

Los valores de las sociedades liberales se ponían en entredicho por la emergencia meteórica del nacionalsocialismo tras su victoria electoral en 1933. Los campos de concentración y toda su carga de violencia y dolor no son un rasgo accidental del régimen nazi, sino la manifestación más acabada de su naturaleza intrínseca, puesto que 
reconoce que las demás ideologías totalitarias como el comunismo tienen una particular concepción de humanidad, en tanto que el nazismo es una manifestación vacía y básica de la maldad humana. Por ello, Amery reclama de manera airada que tras la derrota del fascismo las potencias occidentales hayan guardado una especie de silencio condescendiente con Alemania, que se limitó a juzgar a los máximos responsables dentro de la jerarquía del partido nazi y el ejército alemán, pero que no centró su preocupación central en afianzar la asunción de la responsabilidad y la culpa colectiva en cabeza del pueblo alemán (Marrades, 2005).

Los textos anteriores nos ofrecen un rico esquema teórico, que permite observar como una parte de las víctimas del nazismo en Europa, asumen su condición y toman un camino distinto del que pudiera suponerse más adecuado para expiar sus penas colectivas. La pregunta que formulamos en este texto resulta de una inusitada relevancia para asumir las tareas propias que impone el eventual escenario de pos acuerdo, luego de firmado el cese de la confrontación bélica entre el gobierno nacional y los grupos guerrilleros y paramilitares (Ley de Justicia y Paz y JEP). Es claro que la propuesta de los autores está encaminada a no sacrificar el valor supremo de la justicia y la memoria por salvaguardar el de la paz y la reconciliación nacionales. En tal sentido, podría decirse con entera claridad, las víctimas tienen el legítimo derecho a no perdonar a sus victimarios, y aún más, la sociedad tiene la obligación moral de respetar y respaldar tal determinación. Esto porque el perdón es patrimonio exclusivo de quien ha padecido la victimización y no del interés general o de la voluntad colectiva, así ella persiga el valor genérico de la paz. Aún más, la paz no puede en modo alguno sacrificar el resentimiento, 
el dolor, la necesidad de justicia, de persecución de los responsables de las atrocidades del conflicto interno colombiano. Lo que nos han enseñado Amery y Levi es que también puede guardarse la dignidad en los reclamos legítimos a los victimarios a que reconozcan y paguen por sus crímenes y a la sociedad que detente su culpa y sus penas colectivas por la omisión en no detener la victimización.

Resulta inquietante pensar que el pueblo colombiano con su inveterada indiferencia y pasividad comparta un rasgo con el pueblo alemán que guardó silencio cómplice ante el hecho más vergonzoso en la historia de la humanidad, al parecer lo que nos dicen con dureza Amery y Levi es que todos somos culpables y que carecemos por entero de reclamar a las víctimas que perdonen para salvaguardar nuestra inaceptable comodidad ante su dolor.

\subsection{Activación de la competencia de la Corte Penal Internacional en el caso colombiano.}

Este trabajo se ha dedicado a resaltar los aspectos negativos más protuberantes de la Ley de Justicia y Paz y las críticas más importantes que se han hecho a la JEP. No obstante, la Fiscalía de la Corte Penal Internacional y la jurisprudencia del Tribunal marcan un derrotero de acción de la manera en la que este tribunal actuaría para complementar la jurisdicción interna en los procesos de justicia transicional en las jurisdicciones internas que han emprendido procesos de paz. Es claro que en el caso 
colombiano el Estado tiene instituciones de promoción, investigación y juzgamiento, que funcionan de manera permanente y con arreglo a un sólido sistema judicial.

También resulta evidente que en Colombia hubo una decisión política por encontrar un mecanismo que permita encontrar la verdad, la justicia y la reparación de un amplio universo de víctimas del conflicto armado. En el caso específico de la CPI en el caso colombiano se observa un ánimo de colaboración antes que, de intervención en la capacidad de condena y juzgamiento del aparato judicial interno, así se extracta de los informes anuales de la CPI al respecto. Es difícil determinar que el Estado Colombiano es incapaz o no tiene voluntad de enjuiciar y encarcelar a los responsables de crímenes contra los derechos humanos, más bien se pueden predicar de los esfuerzos del Estado enfocados en buscar la paz y resarcir a las víctimas.

La admisibilidad de una causa judicial ante la Corte Penal Internacional puede presentarse como se ha visto, solo en el supuesto de que logre demostrarse la configuración de alguno de los supuestos que predica el Artículo 17 del Estatuto. Ello no obstante bajo el supuesto que la Ley 975 de 2005 y su proceso de implementación estén encuadrados en el test que plasma el Estatuto de Roma para determinar la admisión de una causa, paso de por si complejo que no parece plausible en relación con la Ley de Justicia y Paz, así sean evidentes las múltiples dificultades que atraviesa esta ley. 


\section{CAPITULO 5}

\section{VERIFICACIÓN DEL ESTÁNDAR INTERNACIONAL DE JUSTICIA EN RELACIÓN CON LAS SENTENCIAS EMITIDAS POR LAS SALAS DE JUSTICIA Y PAZ EN VIRTUD DEL SISTEMA DE JUSTICIA TRANSICIONAL DE LEY 975 DE 2005}

El objetivo de este capítulo es efectuar una relación entre los hechos y las normas; entre una muestra de hechos que son objeto del proceso especial de Justicia Transicional de Ley 975 de 2005, en su mayoría cometidos por Grupos Armados Organizados al Margen de la Ley, denominados Paramilitares, y las normas de carácter internacional y las nacionales que regulan esa relación, concretamente en lo atinente al estándar de Justicia, a fin de verificar su cumplimiento y en caso tal, determinar que es viable la activación complementaria de la Corte Penal Internacional en Colombia.

En capítulos antecedentes, de forma genérica, se mencionaron numerosas falencias del Sistema de Justicia Transicional de Ley 975 de 2005, en relación con el cumplimiento de los estándares de Justicia, Verdad, Reparación y No Repetición, insertos en esta norma y que emanan de tratados internacionales que hacen parte del bloque de constitucionalidad colombiano, que de no cumplirse facultarían la intervención del Tribunal Internacional Penal. 
Ahora, corresponde analizar en concreto y a la luz de las normas internacionales, si el Sistema de Justicia Transicional de Ley 975 de 2005, ha cumplido con el estándar de Justicia a través de una muestra de las decisiones emitidas por las Salas de Justicia y Paz, encargadas de investigar y juzgar a los perpetradores de crímenes cometidos en el marco del conflicto armado que se sometieron a la Ley de Justicia y Paz.

\subsection{Estándar internacional de Justicia - no impunidad}

Ley 975 de 2005 - Artículo 6. Derecho a la justicia. De acuerdo con las disposiciones legales vigentes, el Estado tiene el deber de realizar una investigación efectiva que conduzca a la identificación, captura y sanción de las personas responsables por delitos cometidos por los miembros de grupos armados al margen de la ley; asegurar a las víctimas de esas conductas el acceso a recursos eficaces que reparen el daño infligido, y tomar todas las medidas destinadas a evitar la repetición de tales violaciones.

Las autoridades públicas que intervengan en los procesos que se tramiten con fundamento en la presente ley deberán atender, primordialmente, el deber de que trata este artículo. 
La Justicia es un valor de fundamento constitucional, pilar fundante del Estado Social de Derecho (art. 2, 5, 29 y 229 Constitución Política), garantía de dignidad humana, derechos y convivencia pacífica, por tanto, derecho fundamental (C-426 de 2002).

La noción de estándar se entiende como una pauta o regla articulada por el Sistema Internacional de Protección de Derechos Humanos, especialmente por sus órganos judiciales a los que se encuentran sometidos los procesos de Justicia Transicional y los procesos adelantados en contra de los perpetradores en el marco del conflicto interno, y su incumplimiento propicia la repetición de la vulneración (Quinche, 2009, pp.17).

De acuerdo a los instrumentos internacionales ratificados por el ordenamiento nacional, entre ellos los principios promulgados por la ONU también denominados Louis Joinet, son objetivos del modelo de justicia transicional i) el derecho a saber, ii) el derecho a la justicia, iii) el derecho a obtener reparación, iv) y a la no repetición de los hechos victimizantes.

Concretamente el estándar de justicia, en el sistema internacional de DDIIHH y DDHH, se refiere a la obligación de perseguir, investigar, juzgar y sancionar; investigación que debe conservar un sentido propio asumido por el Estado, por todos los medios legales disponibles, orientada a la determinación de la verdad, persecución, captura, enjuiciamiento, castigo de los responsables tanto mediatos, como inmediatos, así sean sujetos estatales (Caso de la Masacre de Pueblo Bello Vs. Colombia, 2006 y Caso Myrna Mack Chang Vs. Guatemala, 2003). 
La jurisprudencia de la Corte Interamericana de Derechos Humanos, fuente vinculante para el Estado colombiano, ha precisado parámetros insacrificables por un Estado para alcanzar el logro de la paz ${ }^{6}$ :

i) La obligación estatal de prevenir los grandes atentados contra los Derechos Humanos, de investigar y procesal cuando ocurran y sancionar a los responsables, así como lograr la reparación a las víctimas.

ii) Incompatibilidad de las leyes de amnistía, de normas de normas de prescripción y excluyentes de responsabilidad respecto de graves atentados contra los derechos fundamentales.

iii) El derecho de acceso a la justicia de las víctimas de violaciones a los derechos fundamentales y los plazos razonables en los que debe deben desarrollarse las investigaciones.

iv) La no suspensión de las obligaciones de los Estados en materia de investigación y juzgamiento mientras se adelanten los procesos de paz.

v) El deber de reparación estatal.

vi) El derecho a conocer la verdad.

El derecho a la justicia se encuentra establecido en el "Conjunto de Principios para la Protección y la Promoción de los Derechos Humanos mediante la lucha contra la impunidad", proclamados por la ONU en 1998, como el derecho a un recurso justo y

\footnotetext{
${ }^{6}$ Corte Interamericana de Derechos Humanos, sentencias del 20 de enero de 1989, del 14 de marzo de 2001, del 25
} de noviembre de 2003, del 8 de julio de 2004 
eficaz, donde la víctima pueda hacer valer sus derechos a conseguir que el perpetrador sea juzgado obteniendo su reparación:

"(e)I derecho a la justicia confiere al Estado una serie de obligaciones: la de investigar las violaciones, perseguir a sus autores $y$, si su culpabilidad es establecida, de asegurar su sanción. Si la iniciativa de investigar corresponde en primer lugar al Estado, las reglas complementarias de procedimiento deben prever que todas las víctimas puedan ser parte civil y, en caso de carencia de poderes públicos, tomar ella misma la iniciativa."

Como ya se había explicado, el estándar de Justicia en procesos de transición opera de manera excepcional, guiado por el balance de principios como la reconciliación, la paz y los derechos de las víctimas; por ello no obedece a la retribución que opera en tiempos de normalidad y ello demanda que su cumplimiento esté guiado por el equilibrio entre la justicia, la reconciliación, la paz y los derechos de las víctimas.

“(...) El método de ponderación es apropiado para la resolución de los problemas que plantea este caso, por cuanto no es posible materializar plenamente, en forma simultánea, los distintos derechos en juego, a saber, la justicia, la paz, y los derechos de las víctimas. El logro de una paz estable y duradera que sustraiga al país del conflicto por medio de la desmovilización de los grupos armados al margen de la ley puede pasar por ciertas restricciones al valor objetivo de la justicia y al derecho correlativo de las víctimas a la justicia, puesto que, de lo 
contrario, por la situación fáctica y jurídica de quienes han tomado parte en el conflicto, la paz sería un ideal inalcanzable. Se trata de una decisión política y práctica del Legislador, que se orienta hacia el logro de un valor constitucional. En ese sentido, la Ley 975 de 2005 es un desarrollo de la Constitución de 1991. Pero la paz no lo justifica todo. Al valor de la paz no se le puede conferir un alcance absoluto, ya que también es necesario garantizar la materialización del contenido esencial del valor de la justicia y del derecho de las víctimas a la justicia, así como los demás derechos de las víctimas, a pesar de las limitaciones legítimas que a ellos se impongan para poner fin al conflicto armado. (...)" (Corte Constitucional, Sentencia C-370 de 2006).

La Ley 975 de 2005 establece el principio de Alternatividad de la pena en los siguientes términos:

ARTícUlO 30. ALTERNATIVIDAD. Alternatividad es un beneficio consistente en suspender la ejecución de la pena determinada en la respectiva sentencia, reemplazándola por una pena alternativa que se concede por la contribución del beneficiario a la consecución de la paz nacional, la colaboración con la justicia, la reparación a las víctimas y su adecuada resocialización. La concesión del beneficio se otorga según las condiciones establecidas en la presente ley.

ARTículo 29. PENA ALTERnAtIVA. La Sala competente del Tribunal Superior de Distrito Judicial determinará la pena que corresponda por los delitos cometidos, de acuerdo con las reglas del Código Penal. 
En caso que el condenado haya cumplido las condiciones previstas en esta ley, la Sala le impondrá una pena alternativa que consiste en privación de la libertad por un período mínimo de cinco (5) años y no superior a ocho (8) años, tasada de acuerdo con la gravedad de los delitos y su colaboración efectiva en el esclarecimiento de los mismos.

Para tener derecho a la pena alternativa se requerirá que el beneficiario se comprometa a contribuir con su resocialización a través del trabajo, estudio o enseñanza durante el tiempo que permanezca privado de la libertad, y a promover actividades orientadas a la desmovilización del grupo armado al margen de la ley al cual perteneció.

Cumplida la pena alternativa y las condiciones impuestas en la sentencia se le concederá la libertad a prueba por un término igual a la mitad de la pena alternativa impuesta, período durante el cual el beneficiado se compromete a no reincidir en delitos, a presentarse periódicamente ante el Tribunal Superior del Distrito Judicial que corresponda y a informar cualquier cambio de residencia.

Cumplidas estas obligaciones y transcurrido el periodo de prueba, se declarará extinguida la pena principal. En caso contrario, se revocará la libertad a prueba y se deberá cumplir la pena inicialmente determinada, sin perjuicio de los subrogados previstos en el Código Penal que correspondan.

PARÁGRAFO. En ningún caso se aplicarán subrogados penales, beneficios adicionales o rebajas complementarias a la pena alternativa. 
Los críticos del principio de Alternatividad señalan que constituye un sistema de impunidad pues los actores del conflicto armado que han cometido delitos de gravedad en contra de los derechos humanos, se pueden exonerar de parte significativa de la pena ordinaria lo cual afectaría los derechos de las víctimas (Corte Constitucional, C-370 de 2006).

Para la Corte Constitucional, tal norma no vulnera el estándar internacional de justicia en relación con los delitos que se imputen a miembros de GAOML que se hubieran acogido a ella, pues el Estado no decidió amnistiar u olvidar las actuaciones delictuosas, tampoco hace la concesión de un indulto pues no se dispone la extinción de la acción penal ni de la ejecución de la pena en favor de los acogidos a este sistema de justicia transicional.

Se estableció como consecuencia un tratamiento jurídico menos riguroso en comparación con el del Código Penal, pero la pena sigue vigente a pesar de la reducción en los términos de la privación de libertad (Corte Constitucional, Sentencia C-370 de 2006).

La pena estatuida en la Ley 975 de 2005, se encuentra orientada por la alternatividad como medida para alcanzar el bien jurídico de la paz, el cual implica la imposición de una pena ordinaria orientada por los parámetros del Código Penal (pena original y accesoria), cuya ejecución se suspenderá y se concederá el beneficio de la pena alternativa privativa de la libertad de 5 a 8 años. La pena ordinaria debe ser cumplida por el postulado en caso de incumplimiento de los compromisos bajo los cuales se concedió el beneficio de 
la suspensión de la condena; según el análisis de la Corte Constitucional en la sentencia mentada, puede afectarse con la alternatividad el valor de la justicia, pero no de manera desmedida.

- Características de la Alternatividad: (Sentencia C-370 de 2006)

a. Comporta suspensión de la pena determinada en la sentencia; se fija una pena ordinaria según las reglas de Código Penal.

b. La pena alternativa se concede por la contribución del beneficiario a la paz, la colaboración con la justicia, la reparación a las víctimas y su resocialización.

c. La propia Ley establece las condiciones para el otorgamiento de la pena alternativa, las Salas de Justicia y Paz evalúan el cumplimiento de los requisitos para conceder el beneficio.

d. La sentencia fija la pena ordinaria.

e. Si el postulado cumple con las condiciones, en la sentencia se fijará la pena alternativa que consiste en la privación de la libertad de 5 a 8 años.

f. La sentencia impone los compromisos de comportamiento, las obligaciones de reparación moral, económica y extinción de dominio de bienes destinados a la reparación.

g. Cumplida la pena alternativa y las condiciones impuestas en la sentencia, se concederá la libertad a prueba por un término igual a la mitad de la pena alternativa impuesta; periodo dentro del cual el postulado se compromete a no 
reincidir en la comisión de delitos, a presentarse en el Tribunal y a informar el cambio de residencia.

h. Se declarará la pena extinguida si el postulado cumple las obligaciones mencionadas y con el transcurso del paso del tiempo, en caso contrario, podrá ser revocada la pena alternativa y se debe cumplir con la pena ordinaria fijada anteriormente.

i. No pueden aplicarse subrogados penales, beneficios adicionales, rebajas complementarias.

j. Se prevé la acumulación de procesos que se hallen en curso por hechos delictivos cometidos durante y con ocasión de la pertenencia del desmovilizado a un GAOML.

k. También procede la acumulación jurídica de penas si el postulado ha sido condenado por hechos delictivos cometidos con ocasión y durante su pertenencia al GAOML.

I. La pena alternativa no podrá ser superior a la prevista en la ley.

m. No encubre indulto pues no es perdón de la pena; el Tribunal impone la pena ordinaria de acuerdo a las reglas del Código Penal y se concede la Alternatividad como un beneficio condicionado al cumplimiento de los requisitos establecidos en la Ley 975 de 2005; la pena alternativa no anula, invalida o extingue la pena ordinaria por sí sola.

n. La extinción de la pena ordinaria supone el cumplimiento de la pena alternativa, el periodo de prueba y el cumplimiento de las obligaciones derivadas de los requisitos para acceder al otorgamiento del beneficio. 
o. Es acorde a la constitución, no afecta desproporcionadamente el valor justicia.

En conclusión, sistemas de justicia transicional, como el colombiano, fundamentados en los instrumentos internacionales que hacen parte de nuestro bloque constitucional, que imperativamente establecen la prohibición de los crímenes de guerra y de lesa humanidad, deben tomar medidas para que los perpetradores de este tipo de delitos no sean sustraídos de la acción de la jurisdicción a través de amnistías que contribuyan al ocultamiento de los responsables de los delitos mencionados.

\subsection{Verificación concreta del estándar de justicia en relación con la no impunidad - principio de Alternatividad Penal de Ley 975 de 2005.}

Ahora, se precisará la aplicación del estándar de justicia en concreto a través de una muestra de decisiones de las Salas de Justicia y Paz de Ley 975 de 2005 y en lo atinente al principio de Alternatividad, con el fin de verificar si resultan violatorias de los instrumentos internacionales que velan por el respeto de los Derechos Humanos y el Derecho Internacional Humanitario.

- Sentencia del 29 de junio de 2010 - Sala de Justicia y Paz de Bogotá 
- Postulados: Edwar Cobos Téllez alias "Diego Vecino" y Uber Enrique Banquéz alias "Juancho Dique" - Comandantes del Bloque Montes de María y Cana del Dique, respectivamente de las Auto Defensas Unidas de Colombia.

- Delitos: Homicidio agravado, desplazamiento forzado, secuestro, uso privativo de prendas y armas de las Fuerzas Militares, hurto, concierto para delinquir $(1,111$ hechos).

- Víctimas: 1.194 (1.081 víctimas directas de desplazamiento forzado, 90 víctimas directas de homicidio, 17 víctimas directas y 4 víctimas directas de secuestro y 2 víctimas directas de delitos contra el patrimonio)

- Resumen: Ingreso violento de paramilitares a la población de Manpuján el 10 y 11 de marzo de 2000, anunciando a los pobladores que debían salir de la población so pena que les ocurriera los mismo que a la comunidad de El Salado; retención forzosa de 7 pobladores, ejecución de 11 pobladores señalados de ser subversivos. Secuestro de 10 habitantes de Isla Múcura el 19 de abril de 2003, uso de prendas y armas de uso privativo de las fueras militares, hurtos

- Cumplimiento del estándar de Justicia: se condenó a los desmovilizados postulados por graves infracciones al $\mathrm{DIH}$, de cara a delitos comunes y como autores de crímenes de lesa humanidad, a saber, concierto para delinquir (solo para COBOS TELLEZ), deportación, expulsión, traslado o desplazamiento 
forzado de población civil, homicidio agravado en concurso homogéneo, secuestro simple en concurso homogéneo, hurto calificado y agravado en concurso homogéneo, utilización ilegal de uniformes e insignias y fabricación, tráfico y porte de armas y municiones de uso privativo de las fuerzas armadas, motivo por el cual, se determinó la pena de acuerdo al Decreto 100 de 1980 y la Ley 599 de 2000:

“(...) Con fundamento en los anteriores argumentos, los postulados EDWAR COBOS TELLEZ y UBER ENRIQUE BANQUEZ MARTINEZ quedarán sometidos en definitiva a una pena de cuatrocientos sesenta y ocho (468) meses de prisión y multa de mil quinientos (1.500) salarios mínimos legales mensuales vigentes y cuatrocientos sesenta y dos (462) meses de prisión y multa de mil quinientos (1.500) salarios mínimos legales mensuales vigentes, respectivamente, penas que no sobrepasan lo previsto por el numeral 1ํ del artículo 37 de la Ley 599 de 2000. Como pena accesoria que debe ir acompañada de la de prisión se les impondrá a los sentenciados de conformidad con el artículo 44 del C.P., la inhabilitación para el ejercicio de derechos y funciones públicas, por un lapso de veinte (20) años. (...)"

Para el otorgamiento de la pena alternativa, tuvo en cuenta la Sala el cumplimiento de los requisitos de elegibilidad, la contribución a la verdad, la reparación a víctimas y se ordenó la suspensión de la pena por el termino de 8 años, imponiendo a los postulados la suscripción de actas de compromiso de 
resocialización a través de estudio, trabajo o enseñanza durante el tiempo que estuviesen privados de la libertad, a promover actividades orientadas a la desmovilización del GAOML.

\section{- Sentencia del 02 de diciembre de 2010 - Sala de Justicia y Paz de Bogotá}

- Postulados: Jorge Iván Zapata Laverde alias "El Iguano" - Comandante del Bloque Frente Fronteras del Catatumbo de las Auto Defensas Unidas de Colombia.

- Delitos: Concierto para delinquir, homicidio en persona protegida, homicidio agravado, fabricación, tráfico y porte de armas y municiones de uso privativo de las Fuerzas Armadas, tortura, terrorismo, destrucción de bienes protegidos, desplazamientos forzados, contribuciones o exacciones forzadas (32 hechos).

- Víctimas: 170 víctimas directas de homicidio agrupadas en 32 hechos.

- Resumen: Ejecuciones extrajudiciales con el fin de combatir la subversión y sus auxiliadores, y todo lo que afectara el orden social (delincuentes, consumidores de vicio, trabajadores sexuales, en Norte de Santander etc)

- Cumplimiento del estándar de Justicia: se condenó al desmovilizado postulado a una pena de 480 meses de prisión y multa de 4.000 salarios mínimos legales 
mensuales vigentes, y una pena accesoria de inhabilitación para el ejercicio de derechos y funciones públicas por un lapso de 20 años.

Este postulado se hizo merecedor de la suspensión de la pena por una alternativa de 8 años luego de verificarse las condiciones del artículo 29 de la Ley 975 de 2005 (p.p.150).

\section{- Sentencia del 29 de junio de 2011 - Sala de Justicia y Paz de Bogotá}

- Postulados: Aramis Machado Ortiz alias "Cabo Machado", "Martín Moreno" o "Iguano" -del Bloque Frente Fronteras del Catatumbo de las Auto Defensas Unidas de Colombia.

- Delitos: Concierto para delinquir agravado, fuga de presos, fabricación, tráfico y porte de armas de fuego o municiones y fabricación, tráfico de armas y municiones de uso privativo de las fuerzas armadas (32 hechos).

- Víctimas: 170 víctimas directas de homicidio agrupadas en 32 hechos.

- Resumen: “(...) Con ocasión a los contactos sostenidos entre ARAMIS MACHADO ORTIZ y OMAR YESID LÓPEZ ALARCÓN, se decidió el reconocimiento del primero como vocero del grupo ilegal desde el patio 16 y disco del establecimiento carcelario de la ciudad de Cúcuta, encomendándosele la tarea 
de recibir y proteger a los miembros del Bloque que fueren capturados y remitidos a la citada Cárcel, tareas por las cuales el postulado MACHADO ORTIZ, confesó haber recibido una mensualidad que oscilaba entre $\$ 400.00$ y $\$ 700.000$ pesos, actividades que cumplió hasta el día 10 de diciembre del año 2004, fecha en la que el BLOQUE CATATUMBO, declaró su desmovilización colectiva en el municipio de Tibú - Norte de Santander. (...) La vinculación del postulado ARAMIS MACHADO ORTIZ, con el FRENTE FRONTERAS, se hizo evidente cuando participó en las fugas de la Cárcel Nacional Modelo de Cúcuta de los ex comandantes del FRENTE FRONTERAS, JORGE IVÁN LAVERDE ZAPATA, en noviembre del año 2000 y OMAR YESID LÓPEZ ALARCÓN, para el mes de mayo del año 2001(...)"

- Cumplimiento del estándar de Justicia: “(.) Acorde con lo motivado para la dosificación de la sanción a imponer al postulado, se partirá de la pena que corresponda conforme a lo dispuesto por el artículo 340 inciso $2^{\circ}$ y 342 de la Ley 599 de 2000, que como se anotó oscila entre ocho (8) y dieciocho (18) años de prisión, a partir de los extremos que informan el cuanto máximo, que como se dijo, va de 186 a 216 meses de prisión. Establecido el cuarto correspondiente, la sanción se impondrá de acuerdo con la gravedad y modalidad del hecho punible, debe la Sala puntualizar que la colaboración del postulado en la fuga de los ex militantes del Frente Fronteras del Boque Catatumbo de la AUC, es asunto que revistió significativa y particular gravedad, en cuanto a que la evasión de tales personas de su sitio de reclusión, no solo significó la muerte violenta del funcionario de policía judicial que había dado captura a JORGE IVÁN LAVERDE ZAPATA; sino que sus liberaciones se tradujeron en el incremento de las 
condiciones de riesgo a los habitantes de las regiones donde operó esta estructura paramilitar, como que así lo indica la sucesión de desaparecimientos, desplazamientos y homicidios selectivos. Por lo anterior, por el delito de Concierto para delinquir agravado, se impondrá una sanción de 216 meses de prisión. Vale resaltar que el quantum de la pena que se incrementa por la acción concursal de tipos, se deriva de 58 meses que se incrementan por el concurso homogéneo sucesivo del delito de Fuga de presos, 42 meses por el Tráfico de armas de defensa personal, en tanto que por el tráfico de armas de uso privativo, el incremento se tasa en 108 meses de prisión. Estos incrementos, por cuanto en todos los eventos delictivos que concursan las sanciones, se tomaron de los cuartos máximos dada la incidencia exclusiva de circunstancias de agravación punitiva, como lo son las referidas a los numerales 10 y 13 del artículo $58 \mathrm{del}$ Código Penal, pues todas estas conductas no solo se desarrollaron en coparticipación criminal, sino desde el sitio de reclusión en el que se hallaba detenido el postulado. Esta, la medida para indicar que la pena ordinaria y adición por el concurso de delitos punibles será de cuatrocientos veinticuatro (424) meses de prisión. (...)"

Este postulado se hizo merecedor de la suspensión de la pena por una alternativa de 6 años luego de verificarse las condiciones del artículo 29 de la Ley 975 de 2005.

\section{- Sentencia del 09 de diciembre de 2014 - Sala de Justicia y Paz de Medellín}


- Postulados: Jesús Ignacio Roldán Pérez, alias "Monoleche" - miembro de Auto Defensas Campesinas de Córdoba y Urabá.

- Delitos: Concierto para delinquir agravado, homicidio en persona protegida, desaparición forzada, secuestro extorsivo, hurto calificado y agravado

- Víctimas: 13 hechos, 91 víctimas.

Resumen: “(...) El postulado Jesús Ignacio Roldán Pérez, más conocido como Monoleche, acompañó a los hermanos Fidel, Carlos y Vicente Castaño Gil desde 1.988. No sólo estuvo vinculado a ellos durante su trasegar por el departamento de Córdoba y la constitución de los Tangueros, las Autodefensas Campesinas de Córdoba y Urabá y las Autodefensas Unidas de Colombia, sino que fue de su entera confianza. Eso significa que está ligado a la creación, consolidación y expansión de los grupos paramilitares en el país desde sus albores y la Sala debe dar cuenta de ese proceso de constitución y expansión de tales grupos para cumplir con la verdad que reclaman la sociedad y las víctimas y que constituye uno de los principios y fines de la ley de justicia y paz. (...)"

- Cumplimiento del estándar de Justicia: se condenó al postulado Jesús Ignacio Roldán Pérez, conocido como Monoleche, integrante de las Autodefensas Campesinas de Córdoba y Urabá y desmovilizado del bloque Calima, a la pena 
principal de cuarenta (40) años de prisión y multa de once mil novecientos cincuenta (11.950) salarios mínimos legales mensuales vigentes para el año 2005 y a la pena de inhabilitación para el ejercicio de derechos y funciones públicas por un lapso de 10 años, como coautor de los delitos de concierto para delinquir, homicidio en persona protegida, desaparición forzada y hurto calificado agravado.

Este postulado se hizo merecedor de la suspensión de la pena por una alternativa de 95 meses luego de verificarse las condiciones del artículo 29 de la Ley 975 de 2005, y a la libertad a prueba por pena cumplida por el término de 47 meses y 15 días, beneficio que fue revocado por la Corte Suprema de Justicia.

\section{- Sentencia del 04 de septiembre de 2012 - Sala de Justicia y Paz de Bogotá}

- Postulados: Gian Carlo Gutiérrez Suárez, alias "El tuerto”, “Antonio", “Luís” y/o "EI Pirata" - miembro del Bloque Calima de las AUC (Compuesto por 5 frentes Central (ubicado en Tuluá y sus alrededores), Pacífico (ubicado en Buenaventura y algunos municipios costeros de Cauca), Cacique Calarcá (Ubicado en algunos municipios del norte del Valle del Cauca y Quindío), La Buitrera (Ubicado en Palmira y sus alrededores) y Farallones (ubicado en varios municipios de Cauca), desmovilizado patrullero

- Delitos: Homicidio y otros 
- Víctimas: 22 casos que relacionan doce (12) víctimas de homicidio, dieciocho (18) víctimas de secuestro simple agravado y homicidio, una (1) de desaparición forzada, una (1) de desplazamiento forzado y extorsión, y concierto para delinquir; para un total de treinta y dos (32) víctimas directas.

- Resumen: “(...) el postulado confesó haber militado durante aproximadamente tres años en el Bloque Calima entre el 1ํo de enero de 2001 y marzo de 2003, donde ejerció el cargo de patrullero rural y urbano, en desarrollo del cual participó en múltiples conductas criminales como asesinatos, secuestros, desplazamiento forzado y extorsión todos en persona protegida, delitos por los que posteriormente se le formulo imputación ante el Magistrado de control de garantías de Justicia y Paz respectivo. (...)"

- Cumplimiento del estándar de Justicia: se condenó a este desmovilizado postulado a la pena principal de 40 años de prisión, multa de 5.000 salarios mínimos legales mensuales vigentes, e inhabilitación para el ejercicio de derechos y funciones públicas por 20 años, por graves infracciones al Derecho Internacional Humanitario y por la comisión de crímenes de lesa humanidad, por atacar de manera generalizada y sistemática a personas protegidas por el DIH, quienes no estaban en condiciones de repeler los ataques, indistintamente de la lectura arbitraria y caprichosa de que las víctimas hayan favorecido o militado en algún grupo subversivo, como la mayoría de las veces les señalaron. 
Este postulado se hizo merecedor de la suspensión de la pena por una alternativa de 8 años.

- Sentencia del 01 de agosto de 2014 - Sala de Justicia y Paz de Barranquilla

- Postulados: Luis Carlos Pestana Coronado, alias "El Cachaco" - miembro del Bloque Norte de las AUC - Frente Juan Andrés Álvarez

- Delitos: Concierto para delinquir agravado, secuestro, desplazamiento forzado, homicidio agravado, porte ilegal de armas de uso privativo de las fuerzas militares y tortura en persona protegida.

- Víctimas: 10 víctimas directas y 106 víctimas indirectas.

- Resumen: “(...)perteneció al Bloque Norte de las Autodefensa Unidas de Colombia-AUC-, frente "Juan Andrés Álvarez", ingresando en el mes de junio de 1997, por intermedio de un amigo del grupo llamado Diomedes Iván Viloria, alias "Iván o Nariz de Palo", efectuando su vinculación en la trocha de Verdecía del municipio de Codazzi - Cesar, recibiendo al momento de su ingreso un curso de entrenamiento de 15 días, dictado por alias "Carlos" comandante de las AUC, en una finca llamada "La Estrella" ubicada en Chivolo-Magdalena; desempeñándose siempre dentro del grupo armado organizado al margen de la ley como patrullero y recibiendo durante su permanencia en las AUC una bonificación de $\$ 150.000$ 
pesos mensuales, suma que ascendió a \$250.000 estando privado de la libertad. Las funciones desarrolladas por el postulado en el grupo, tal como él mismo lo informó, eran la de prestar guardia, cocinar y patrullar la zona del corregimiento de la Loma de Potrerillo en jurisdicción del municipio de El Paso-Cesar, con el propósito que el enemigo -la guerrilla- no ingresara al área por ellos dominada, para lo cual utilizaba armas como fusiles AK-47 con cuatro proveedores, pistolas y morteros. (...)"

- Cumplimiento del estándar de Justicia: se condenó a este desmovilizado postulado a la pena principal de 480 meses equivalente a 40 años de prisión, multa de 7.100 salarios mínimos legales mensuales vigentes, e inhabilitación para el ejercicio de derechos y funciones públicas por 20 años.

Este postulado se hizo merecedor de la suspensión de la pena por una alternativa de 8 años.

- Sentencia del 09 de septiembre de 2016 - Sala de Justicia y Paz de Medellín

- Postulados: Fredi Alonso Pulgarín Gaviria, alias "La Pulga" - Comandos Armados del Pueblo CAP- patrullero. 
- Delitos: Rebelión, deportación, expulsión, traslado o desplazamiento de población civil, homicidio en persona protegida, homicidio agravado, tentativa de homicidio en persona protegida -19 delitos legalizados.

- Víctimas: 60 víctimas.

- Resumen: “(...) Los CAP, se remonta a la desmovilización de las Milicias Populares en 1994, proceso en el cual, algunos miembros que quedaron en los barrios empezaron a abusar del poder y de las armas; hurtaban, cobraban celadurías, vacunas, asesinaban personas por dinero, violaban muchachas y se vanagloriaban de ello, creándose entonces en respuesta el grupo al que perteneció. (...) Su incorporación al GAOML se produjo a mediados del año 1997, cuando ya era mayor de edad, en el barrio Metropolitano de Medellín, donde residía con su familia; permaneció en el mismo casi seis años hasta que desertó de la organización entre octubre y diciembre de 2002, después de la Operación Orión a cargo del Ejército Nacional y otras autoridades en la Comuna 13, fecha en la cual también terminó el actuar oficial de los Comandos Armados del Pueblo CAP. En versión libre del 10 de febrero de 2015, el postulado ha hecho referencia a su pertenencia al GAOML, Ilamado Comandos Armados del Pueblo-CAP-, que hizo presencia en la zona urbana de la Comuna 13 de la ciudad de Medellín, en el periodo comprendido entre enero de 1997 al 5 de enero de 2006, momento en el que lo capturan señalado de haber participado en el homicidio del sacerdote 
JOSÉ LUÍS ARROYAVE RESTREPO, por el cual fue condenado a 390 meses de prisión y multa de 3.000 SMLMV. (...)"

- Cumplimiento del estándar de Justicia: se condenó a este desmovilizado postulado a la pena principal de 480 meses de prisión, multa de $32.667,5$ salarios mínimos legales mensuales vigentes, e inhabilitación para el ejercicio de derechos y funciones públicas por 120 meses.

Este postulado se hizo merecedor de la suspensión de la pena por una alternativa de 8 años.

\section{- Sentencia del 28 de abril de 2016 - Sala de Justicia y Paz de Medellín}

- Postulados: José Higinio Arroyo Ojeda, alias "8.5, Caballo o Julián" y otros comandantes del Bloque Mineros de las AUC.

- Delitos: Contra el DIDH y DIH, concierto para delinquir agravado, homicidio en persona protegida, desaparición forzada, hurto calificado y agravado, tortura en persona protegida, lesiones personales, extorsión, delitos de violencia basada en género, reclutamiento ilícito, entrenamiento para actividades ilícitas, toma de rehenes y desplazamiento forzado de población civil.

- Víctimas: 4.025 víctimas entre directas e indirectas. 
- Resumen: “(...) postulados JOSÉ HIGINIO ARROYO OJEDA, alias "8-5, Caballo o Julián", comandante del Frente Briceño; ROBERTO ARTURO PORRAS PÉREZ, alias "La Zorra o Calabozo", comandante del Frente Barro Blanco; ROLANDO DE JESÚS LOPERA MUÑOZ, alias "Mono o Milton", comandante del Frente Anorí; LUIS ALBERTO CHAVARRÍA MENDOZA, alias "Lucho Mico, Mico, Cuatro Cuatro o -Nigo", comandante de los corregimientos de Uré y Versalles (municipio de Montelíbano, Córdoba)1, así como del corregimiento La Caucana del municipio de Tarazá, Antioquia y de contraguerrilla en el municipio de Tarazá, y de los patrulleros LUIS CARLOS GARCÍA QUIÑONES, alias "Cedro"2, y EUCARIO MACÍAS MAZO, alias "Mazo, N.N. o Jerry", todos ellos desmovilizados del Bloque Mineros de las autodenominadas Autodefensas Unidas de Colombia "A.U.C."..(...)"

El 2 de diciembre de 2005, en la Hacienda La Ranchería, vereda Pecoralia del municipio de Tarazá, Antioquia, tuvo lugar la desmovilización colectiva del Bloque Mineros de las AUC comandado por Ramiro Vanoy Murillo, alias "Cuco Vanoy", representante de las Autodefensas Unidas de Colombia.

El Bloque Mineros de las AUC tuvo injerencia en la región del Bajo Cauca Antioqueño está conformada por los municipios de Cáceres, Caucasia, El Bagre, Nechí, Tarazá y Zaragoza y su entorno constituido por los municipios de Amalfi, Anorí, Ituango, Segovia y Valdivia, caracterizada por la producción de oro. 
Comprende las tierras entre las planicies de la parte baja del río Cauca y las estribaciones occidentales de la Serranía de San Lucas, entre los ríos Nechí y Cauca. En el proceso de expansión de este bloque paramilitar se perpetraron masacres como la de "La Granja" el 11 de julio de 1996, la de "El Aro" del 22 al 31 de octubre de 1997, "Masacre de Peque" entre el 3 y 8 de julio de 2001, entre otras acciones violatorias de derechos humanos y del Derecho Internacional Humanitario.

- Cumplimiento del estándar de Justicia: se condenó a estos desmovilizados postulados a la pena principal de 480 meses equivalente a 480 meses de prisión, multa de 50.000 salarios mínimos legales mensuales vigentes, e inhabilitación para el ejercicio de derechos y funciones públicas por 240 meses.

Estos postulados se hicieron merecedores de la suspensión de la pena por una alternativa de 8 años.

- Sentencia del de agosto de 2014 - Sala de Justicia y Paz de Medellín

- Postulados: Uber Darío Yáñez Cavadías, alias "orejas o veintiuno" - comandante militar del Bloque "Héroes de Tolová" de las Autodefensas Campesinas de Córdoba y Urabá. 
- Delitos: Concierto para delinquir en concurso heterogéneo con homicidio en persona protegida; concurso heterogéneo de tortura en personas protegidas, desplazamiento forzado, despojo en campo de batalla, hurto calificado y agravado, tráfico, fabricación o porte de estupefacientes, constreñimiento al sufragante y reclutamiento ilícito.

- Víctimas: 96 víctimas directas e indirectas.

- Resumen: Este bloque paramilitar se remonta a la creación de agrupaciones de seguridad privadas denominadas CONVIVIR en el departamento de Córdoba que desencadenaron en la conformación de grupos ilegales armados al mando de Carlos Castaño Gil, propietario de una finca ubicada entre las verdeas "El Diamante" y "Tolová" del municipio de Tierralta. Luego de enfrentamientos sostenidos con grupos guerrilleros el 28 de diciembre de 1998, Castaño Gil, como líder de grupos paramilitares que tenían injerencia en Córdoba y Urabá Antioqueño, toma la decisión de reforzar la zona encomendando a su amigo persona Diego Fernando Murillo Bejarano, alias "Berna", la creación de un grupo armado para lograr dominio territorial en el sur del departamento de Córdoba y hacer frente a la avanzada subversiva, denominándose "Héroes de Tolová".

Este bloque tuvo injerencia en el norte y occidente de Antioquia, así como en el sur de Córdoba en los municipios de San Juan y San Pedro de Urabá, Arboletes, Apartadó, Valencia y Tierralta; se caracterizó por el ataque a los civiles, muertes 
selectivas o "limpieza social" a través de la "masacre del diamante" del 28 de diciembre de 1998 y la "masacre de San José de Apartadó" perpetrada el 21 de febrero de 2005.

El postulado perteneció a esta organización criminal desde el mes de septiembre de 2002, pasó a formar parte del grupo de seguridad personal de Diego Fernando Murillo Bejarano, alias "Berna” en el municipio e Valencia, Córdoba, en el mes de noviembre de 2004 fue ascendido a comandante militar hasta junio de 2005, fecha de su desmovilización. Participó en la masacre de "San José de Apartadó" en la que fallecieron 8 miembros de la sociedad civil, dentro de los que se encontraban dos menores de edad.

- Cumplimiento del estándar de Justicia: se condenó a este desmovilizado postulado a la pena principal de 480 meses equivalente a 40 años de prisión, multa de 50.000 salarios mínimos legales mensuales vigentes, e inhabilitación para el ejercicio de derechos y funciones públicas por 240 meses.

Este postulado se hizo merecedor de la suspensión de la pena por una alternativa de 8 años.

Del estudio de las sentencias mencionadas podemos concluir: 
- Las Salas Justicia y Paz han observado fielmente el estándar de justicia y el principio de Alternatividad que orienta finalmente la pena a imponer a quienes se acogieron al Sistema de Justicia Transicional de Ley 975 de 2005.

- La imposición de la pena alternativa no comporta amnistía o indulto en favor de los postulados pues la pena dosificada bajo los parámetros del Código Penal recobra vigencia en caso de incumplimiento de los compromisos y obligaciones de los postulados acogidos a este Sistema de Justicia Transicional, no quedan conductas punibles sin sanción.

- La Corte Suprema de Justicia, en decisiones de segunda instancia, mantuvieron en firme la concesión del beneficio de Alternatividad y solo en algunos casos efectuaron ajustes en la dosificación de las penas ordinarias de acuerdo al artículo 61 del Código Penal que establece los criterios para justipreciar la sanción.

- La Corte Suprema de Justicia, como juez de segunda instancia, también ordenó a las Salas de Justicia y Paz que se efectuara la tasación punitiva en concreto, para cada conducta punible y no de manera general.

- La dosificación punitiva ordinaria y el otorgamiento del beneficio de Alternatividad para los autores de conductas violatorias de Derechos Humanos y del Derecho Internacional Humanitario en el marco del conflicto armado, es en definitiva el resultado de la ponderación del estándar de justicia y del fin constitucional de la 
paz; si bien debe sacrificarse en parte el primero de ellos, no se mengua 0 extingue en totalidad, sino que debe ceder en la relación de tensión presentada como instrumento para alcanzar el segundo.

- En últimas, verificado el cumplimiento del estándar de justicia en las decisiones emitidas por las Salas de Justicia y Paz, en virtud de la Ley 975 de 2005, en relación con el principio de no impunidad para los autores de crímenes que atentan contra el Derecho Penal Internacional, no resulta factible la activación de la competencia residual de la Corte Penal Internacional en Colombia. 


\section{CONCLUSIÓN}

Frente a los estándares de verdad y justicia se llegó a colegir que hubo una dispersa individualización de los altos responsables y caracterización de las personas que hacían - o hacen -parte de la estructura paramilitar, tanto desde lo horizontal como lo vertical, y aún siguen en curso investigaciones en contra de responsables. En materia de reparación integral, el panorama para las víctimas es complejo. Adicional al hecho de que los paramilitares no cumplieron el compromiso de entregar la totalidad de los bienes y los que existen son inadecuados para reparar a las víctimas, por lo que el presupuesto estatal ha tenido que ser invertido cuantiosamente para suplir esta falencia, tampoco se ha cumplido con el propósito de encontrar todos los cuerpos desaparecidos y comunidades enteras siguen a la espera de medidas de ayuda humanitaria, reparación, rehabilitación y retorno al estado previo al conflicto.

De acuerdo a lo que se logró identificar y colegir del análisis de este sistema de justicia transicional, el balance de lo recorrido en materia de verdad, justicia, reparación integral y garantías de no repetición es negativo y deficiente; tanto derivado del incumplimiento de los compromisos adquiridos por los postulados, así como de las labores de investigación y verificación de la Fiscalía, como de la gestión adelantada por la Rama Judicial en su conjunto, precisamente de los magistrados y magistradas de los tribunales de Justicia y Paz en todo el territorio nacional. 
Así las cosas, La Ley de Justicia y Paz, como forma específica adoptada en Colombia de Justicia Transicional, puede activar residualmente la competencia subsidiaria y complementaria de la Corte Penal Internacional, en primer lugar, o llevar al Estado Colombiano ante los estrados de responsabilidad de la $\mathrm{CIDH}$, en segundo lugar, como efecto directo de la violación flagrante de los estándares internacionales de justicia cuando se juzga a los máximos responsables de la comisión de los más graves delitos internacionales. En cualquiera de los dos supuestos, la capacidad el Estado de imponer las penas y las sanciones jurídicas, es decir la facultad lus Pudiendi atribuida al Estado se ve seriamente amenazada por la naturaleza excepcional y transitoria de la Justicia Transicional.

En este orden de ideas, estarían sometidos al máximo tribunal penal internacional los líderes o cabecillas de los Grupos Armados Organizados al Margen de la Ley acogidos al Sistema de Ley 975 de 2005 (paramilitares, autodefensas, grupos guerrilleros), también miembros de la fuerza pública y autoridades del gobierno, cuya responsabilidad en crímenes de genocidio, de guerra y lesa humanidad se haya determinado con ocasión de los hechos investigados en virtud de dicha normatividad, así sea de manera mediata.

No obstante, esta realidad, es poco probable que la competencia de dicho tribunal se active, así los errores en la aplicación de la Ley de Justicia y Paz sean evidentes y su ejecución se encuentre llena de dificultades, ello porque la situación actual de los procesos debe encuadrarse en el test que plasma el Estatuto de Roma para determinar la admisión de una causa. Al respecto, el Estado Colombiano, muy a pesar de las 
dificultades, no ha claudicado en el objetivo de investigar y llevar hasta su culminación los procesos que se encuentran en curso, los directores de los mismos han ordenado compulsar copias para que sean investigados miembros de las fuerzas militares, de policía, e incluso en contra de altos miembros del Gobierno implicados en el conflicto armado; el legislador ha fortalecido jurídicamente las herramientas de ayuda y reparación para las víctimas, cuestión que en la práctica se espera se optimice y finalmente se satisfagan los fines insertos en la Ley 975 de 2005.

En suma, la comunidad internacional y más concretamente la Fiscalía de la Corte Penal Internacional, a pesar las críticas y recomendaciones efectuadas frente al proceso de Justicia y Paz, tampoco desconocen los esfuerzos positivos del Estado Colombiano para cumplir los estándares internacionales de no impunidad y reparación. Por tanto, la verdad que continúa de develación en develación, la culminación de los procesos con sentencias condenatorias efectivas, la efectiva reparación de las víctimas y la no repetición de los hechos victimizantes, serán la garantía para que el máximo tribunal penal del orden internacional no deba intervenir en la soberanía punitiva colombiana. 


\section{Bibliografía}

Alcaldía Mayor de Bogotá. 2012. "Atención, asistencia y reparación integral a las víctimas del conflicto armado interno". Proyecto de Presupuesto 2013 Bogotá. Bogotá D.C : Alcaldia Anexo 4.

Ambos, K. (2013). ¿Castigo sin soberano? lus Pudiendi y función del derecho penal internacional. Bogotá D.C: Universidad Externado de Colombia.

Ambos, K. (2008). “El Marco Jurídico de la Justicia de Transición”. Bogotá D.C : Temis, 2008.

Ambos, K. (2004). Problemas seleccionados en torno a los crímenes más graves en el derecho internacional. Bogotá D.C: Ibañez.

Ambos, K. (2010). Procedimiento de la ley de justicia y paz (Ley 975 de 2005) y derecho penal internacional. Estudio sobe la facultad de intervención complementaria de la Corte Penal Internacional a la luz del denominado proceso de "justicia y paz" en Colombia. Bogotá D.C.: Ministerio de Relaciones Internacionales. GTZ, TEMIS.

Amery, J. (2004). Más allá de la culpaTentativas de superación de una víctima de la violencia. Valencia : Pretextos.

Ávila, M. (2014). La adecuación del derecho interno al Estatuto de la Corte Penal Internacional. Bogotá D.C: Universidad Externado de Colombia. 
Centro de Memoria Historica . (2012). Justicia y paz, verdad judicial o verdad historica. Bogotá D.C: Centro de Memoria Historica.

Centro de Memoria Histórica. (2014). Justicia y Paz, Tierras y territorios en las versiones de los paramilitares. Bogotá D.C: Centro de Memoria Histórica.

Comisión Colombiana de Juristas. ( 2007). Anotaciones Sobre la Ley de Jiusticia y Paz. Anotaciones desde las victimas. Bogotá D.C: CCJ.

Comisión Colombiana de Juristas. (2007). Principios Internacionales sobre impunidad y reparaciones. Bogotá D.C: CCJ.

Comisión Colombiana de Juristas. (2011). Despojo de tierras campesinas y vulneración de los territorios ancestrales. Consideraciones generales sobre la cuestión del despojo y restitución de tierras. Bogotá D.C: Opciones Graficas.

Comisión Interamericana de Derechos Humanos CIDH. (1997). INFORME № 5/97. Whashington: $\mathrm{CIDH}$.

Congreso de la República de Colombia. (2005). Ley 975 de 2005. Bogotá D.C: Gaceta Oficial Congreso de la Republica.

Congreso de la República de Colombia. (2011). Ley 1448 del 10 de junio de 2011. "Por la cual se dictan medidas de atención, asistencia y reparación integral a las víctimas del conflicto armado interno y se dictan otras disposiciones". Bogotá D.C: Min. Interior.

Consejo de Estado, Sección Tercera. (2014). Sentencia de unificación del 28 de agosto de 2014, Exp. 32988. Bogotá D.C: Consejo de Estado. 
Consejo de Estado, Sección Tercera. (2015). Auto 85001233100017801 del 7 de septiembre de 2015. Bogotá D.C: Consejo de Estado.

Contraloría General de la República . 2017. Análisis de los resultados y costos de la Ley de Justicia y Paz . Bogotá D.C: Contraloría General de la República , 2017.

Corte Constitucional de Colombia. (2006). Sentencia C - 370 de 2006. Bogotá D.C: Corte Constitucional.

Corte Constitucional de Colombia. (1993). Sentencia C-565/93. Bogotá D.C: Corte Constitucional.

Corte Constitucional de Colombia. (2002). Sentenia C 588/2002. Bogotá D.C: Corte Constitucional.

Corte Constitucional de Colombia. 2010. Sentencia T 458 de 2010. Bogotá D.C: Corte Constitucional.

Corte Interamericana de Derechos Humanos Caso Masacre de el Mozote y lugares aledaños. (2012). CASO MASACRES DE EL MOZOTE Y LUGARES ALEDAÑOS. San José de Costa Rica : Corte Interamericana de Derechos Humanos.

Defensoría del Pueblo. GIZ (Deustche Gesellschaff für Internationale Zusammnarbeit GIZ Gmbh) . (2012). "Contenido y alcance de la reparación instrumentos para la protección y observancia de los derechos de las víctimas. Bogotá : Defensoria. 
Faúndez, H. (2004). El Sistema Interamericano de Protección de los Derechos Humanos. San Jose de Costa Rica : CIDH.

Fiscalía General de la Nación. (2013). Seminario Internacional. Importancia en la construcción de contexto en investigaciones judiciales. Bogotá D.C. : FGN.

Forer, A. (2018). Los logros de Justicia y Paz. Bogotá D.C: Corporación Excelencia en la Justicia.

Garay, L. (2013). El reto ante la tragedia humana del desplazamiento forzado. Superar la exclusión social de la población desplazada. Bogotá D.C: Comisión de Seguimiento a la Política Pública Sobre Desplazamiento Forzado.

Gasser, H. El derecho internacional humanitario y la protección de las víctimas de la guerra. Sin ciudad: CICR.

Gobierno de Colombia. Informe del Gobierno Nacional a las comisiones primeras del Congreso de la República, Abril de 2018. Bogotá D.C: Gobierno de Colombia.

González, J. (2013). Atención a víctimas del conflicto armado interno. Bogotá D.C: Defensoria del Pueblo.

GTZ. PROFIS. (2010). Daño y Reparación Judicial en el ámbito de la ley de Justicia y paz. Ediciones Agencia GTZ, Bogotá: 2010. P. 39. Bogotá D.C: Debate.

Guzman, D.E, Sánchez. N., \& Umprimny, R. (2010). "Las víctimas y la justicia transicional. Están cumpliendo los Estados Latinoamericanos con los estándares internacionales". Washington: Fundación Para el Debido Proceso Legal. 
Hernández, D. (2012). Derecho Internacional Humanitario. La Corte Penal Internacional, su estructura y sus funciones. Pronunciamientos de Tribunales Internacionales y de la CPI. Bogotá D.C: Ediciones Nueva Jurídica.

Huyse, L (2013). La justicia transicional después de la guerra y la dictadura: aprendizajes desde la experiencia europea (1945-2010). Bruselas : CEGES-SOMA.

Ibañez, A. (2003). El sistema penal en el Estatuto de Roma. Bogotá D.C: Universidad Externado de Colombia.

Martinez, Sanabria. \& Claudia M. (2012). La restitución de tierrcoas en Colombia, expectativas y retos. Bogotá D.C: Prolegomenos.

Levi, Primo. (2005). Trilogía de Auschwitz. Los Hundidos y los Salvados. Madrid: Océano.

Marrades, J. (2005). Resentimiento y Verdad. Sobre la réplica de Amery a Nietzsche. Valencia : Universidad de Valencia.

Mcausland, M. (2010). Daño y repraración integrall en el ámbito de la ley 975 de 2005. Bogotá D.C: GTZ. FGN.

Ministerio de Salud y Protección Social. (2012). Procedemiento para entrega digna de cadáveres de víctimas de desaparición forzada y homicidio en el marco del conflicto armado interno. Bogotá D.C: Ministerio de Salud y Protección Social.

Monroy, G. (2010). Tratado de Derecho Internacional Publico. 2ª ed. Bogotá D.C: Temis.

Nash, C. (2004). Las reparaciones ante la Comisión Interamericana de Derechos Humanos (1988 - 2007). Santiago de Chile: Universidad Católica. 
Olásolo, H. (2015). Introducciòn al derecho internacional penal. Valencia: Tirant Lo Blanc.

Orellana O. (2003). La individualización de la pena de prisión. Mexico D.F: Editorial Porrúa.

Organización Naciones Unidas . (1999). Estatuto de la Corte Penal Internacional. Roma: ONU.

Patiño, M. (2006). Derecho de la víctima a obtener reparación. Especial consideración a la Ley 975 de 2005. Bogotá D.C: Universidad Nacional de Colombia.

Procuraduría General de la Nación. (2007). Primero las victimas. Criterios para la reparación de victimas individuales y grupos etnicos. Bogotá D.C.: PGN.

Procuraduria General de la Nación. (2008). Conceptos básicos acerca de la Ley 975 de 2005, Justicia y Paz y de los derechos de las víctimas. Bogotá D.C: PGN.

Quesada, C. (2005). La Corte Penal Internacional y la soberanía estatal. Madrid: Tirant Lo Blanc.

Ramelli, A. (2003). La Constitución Colombiana y el Derecho Internacional Humanitario Bogotá D.C: Universidad Externado de Colombia.

Rettberg, A. (2005). Entre el perdón y el paredón: preguntas y dilemas de la Justicia Transicional. Bogotá D.C: Ediciones Uniandes.

Romeike, S. (2016). Caso de estudio No. 1 La justicia transicional en Alemania después de 1945 y después de 1989. Nuremberg: International Nuremberg Principles Academy. 
Saavedra, E. \& Gordillo, C. (2005). Derecho Penal Internacional: Jurisprudencia de derechos humanos. Cali: USC.

Salmón, E. (2004). Introducción al Derecho Internacional Humanitario. Lima: CICR.

Sánchez, N. (2013). ¿Qué es la Justicia Transicional? Bogotá D.C: Defensoria del Pueblo.

Stahn, C. 2006. La geometria de la justicia transicional: opciones de diseño institucional. Bogotá D.C: Univerisidad de los Andes.

Tribunal Superior de Medellín, Sala de Justicia y Paz. Oficio 07 Complemento al informe Análisis sobre resultados de la Ley de Justicia y Paz. Medellín: Sala de Justicia y Paz de Antioquia.

Unidad de Atención y Reparación Integral a las Víctimas. 2016. Informe ejecutivo. Fondo para la reparación de las victimas, septiembre de 2016. Bogotá D.C.: Unidad para las Víctimas.

Uprimny, R. (2008). Bloque de constitucionalidad, derechos humanos y nuevo procedimiento penal. Dejusticia.

Uprimny, R. (2006). Las enseñanzas del análisis comparado: procesos transicionales, formas de justicia transicional y el caso colombiano. Bogotá D.C: Dejusticia, 2006..

Uprimny, R. (2006). ¿ ¿usticia transicional sin transición? Verdad, justicia y reparación. Bogotá D.C: Centro de Estudios de Derecho, Justicia y Sociedad (DeJuSticia).

Uprimny, R. (2006). Bloque de Constitucionalidad, Derechos Humanos y Proceso Penal. Bogotá D.C: Consejo Superior de la Judicatura. 
Uprimny, R. \& Saffon, M. 2006. ¿Al fin, ley de justicia y paz? La ley 975 de 2005 tras el fallo de la Corte Constitucional. Justicia transicional sin transición. . Bogotá D.C.: Dejusticia.

Uprimny, R. (2006). Derecho a la verdad: Alcance y limites de la verdad judicial. Bogotá D.C: Dejusticia, 2006.

Villamizar, Darío. 2017. Las Guerrilas en Colombia. Bogotá D.C. : Debate. Random House Mondadori.

Weber, M. (2002). Economía y Sociedad. Mexico D.F: Fonde de Cultura Económica.

Werle, G. (2011). Tratado de Derecho Penal Internacional. Segunda Ediciòn . Valencia : Tirant Lo Blanc.

Wolffughel, C. (2011). El principio de complemetariedad en la Ley de Justicia y paz. Principales desafios. Bogotá D.C: Universidad Sergio Arboleda.

\section{Artículos}

1. Acto legislativo $\mathrm{n}^{\circ} 01$ del 04 de abril de 2017. Recuperado de http://es.presidencia.gov.co/normativa/normativa/ACTO\%20LEGISLATIVO\%20N \%C2\%B0\%2001\%20DE\%204\%20DE\%20ABRIL\%20DE\%202017.pdf

2. ABC Jurisdicción Especial para la Paz. Recuperado de http://www.altocomisionadoparalapaz.gov.co/Documents/informesespeciales/abc-del-proceso-de-paz/abc-jurisdiccion-especial-paz.html 
3. Arango, M. (2004). El bloque de constitucionalidad en la jusrisprudencia de la corte constitucional colombia. Precedente revista jurídica. Recuperado de http://www.icesi.edu.co/contenido/pdfs/03.pdf

4. Barbosa, F. (2017). La paz, la JEP y sus retos. El tiempo. Miérocles, 2017, Vol. 1, Opinión.

5. Dura advertencia de la Corte Penal Internacional a Colombia. El Tiempo. 2 de diciembre , 2014, Vol. 1.

6. El plan B para sacar adelante la JEP. Recuperado de http://caracol.com.co/radio/2017/11/01/judicial/1509538485 829676.html

7. El poder disciplinario de Michel Foucault: un itinerario en torno a la libertad y a la $\begin{array}{llll}\text { concepción del tiempo. } & \text { Recuperado }\end{array}$ http://www.elseminario.com.ar/biblioteca/Kibudi Poder Discplinario Libertad Ti empo.pdf

8. La JEP ¿Por qué apenas se menciona la Justicia Especial para la Paz se piensa en los empresarios? Recuperado de http://www.eltiempo.com/opinion/columnistas/gustavo-duncan/la-jep-problemasde-la-justicia-especial-para-la-paz-75330

9. Martínez, Claudia \& Pérez, Andrea, 2012. La restitución de tierras en Colombia, expectativas y retos. Prolegómenos. Derechos y valores, volumen 29, p. 112-127. Recuperado de http:// http://www.redalyc.org/articulo.oa?id=87625419008 
10. Presidente Duque, estas son las 10 deudas del estado con las víctimas. Recuperado de http:// colombia2020.elespectador.com/politica/presidente-duqueestas-son-las-10-deudas-del-estado-con-las-victimas

11. ¿Sabe qué es la Jurisdicción Especial para la Paz y qué la compone? Recuperado de $\quad$ http://www.elpais.com.co/proceso-de-paz/sabe-que-es-la-jurisdiccionespecial-para-la-paz-y-que-la-compone.html

12. Valencia, G. \& Mejía C, (2010). Ley de Justicia y Paz, un balance de su primer lustro. Perfil de Coyuntura Económica. Medellín Universidad de Antioquia. Volumen No. 15. 